\title{
ASPECTOS FISIOLÓGICOS, BIOQUÍMICOS E MICROBIOLÓGICOS EM BETERRABAS MINIMAMENTE PROCESSADAS
}

\author{
MARIA CAROLINA DARIO VITTI
}

Dissertação apresentada à Escola Superior de Agricultura "Luiz de Queiroz", Universidade de São Paulo, para obtenção do título de Mestre em Ciências, Área de Concentração: Fisiologia e Bioquímica de Plantas.

PIRACICABA

Estado de São Paulo - Brasil

Abril - 2003 


\title{
ASPECTOS FISIOLÓGICOS, BIOQUÍMICOS E MICROBIOLÓGICOS EM BETERRABAS MINIMAMENTE PROCESSADAS
}

\author{
MARIA CAROLINA DARIO VITTI \\ Engenheiro Agrônomo
}

Orientador: Prof. Dr.: RICARDO ALFREDO KLUGE

Dissertação apresentada à Escola Superior de Agricultura "Luiz de Queiroz", Universidade de São Paulo, para obtenção do título de Mestre em Ciências, Área de Concentração: Fisiologia e Bioquímica de Plantas.

PIRACICABA

Estado de São Paulo - Brasil

Abril - 2003 


\section{Dados Internacionais de Catalogação na Publicação (CIP) DIVISÃO DE BIBLIOTECA E DOCUMENTAÇÃO - ESALQ/USP}

Vitti, Maria Carolina Dario

Aspec tos fisio lógicos, bioquímic ose mic robiológic osem beterrabas minimamente processadas / Maria Carolina Dano Vitti. - - Piracicaba, 2003.

116 p. : il.

Dissertação (mestrado) - - Escola Superior de Agricultura Luiz de Queiroz, 2003.

Bibliografia.

1. Beterraba 2. Bioquímica de a limentos 3. Fisiologia pós-colheita 4. Mic robiologia de a limentos 5. Pigmentos vegeta is 6. Processamento de a limentos I. Título

CDD 633.41

'Permitida a cópia total ou parcial deste documento, desde que citada a fonte - $\mathrm{O}$ autor" 
"As melodias simples são as mais difíceis de tocar." (Gary Goldschneider) 
Aos meus pais: Nídia e Vail, pelos ensinamentos de vida, pelo amor e por estarem ao meu lado sempre!!!!

\section{DEDICO.}

Aos meus irmãos: Gabriela, Patrícia e Tiago, pelo constante incentivo e amizade verdadeira.

Aos meus avós: Isabel e Augusto, e Duzolina e Amadeu (in memorian), pelo grande carinho. 


\section{AGRADECIMENTOS}

A Deus, por proteger meu caminho e possibilitar a realização deste trabalho, mostrando que nada acontece por acaso.

À Comissão do Programa de Pós-Graduação em Fisiologia e Bioquímica de Plantas, pela oportunidade de realização deste curso.

À Coordenação de Aperfeiçoamento de Pessoal de Nível Superior, pela concessão da bolsa de estudo.

À Fundação de Amparo àPesquisa do Estado de São Paulo e ao Projeto C\&T em Apoio a Agricultura Familiar (CNPq), pelo suporte financeiro.

Ao Prof. Dr. Ricardo Alfredo Kluge, pela excelente orientação, apoio dedicado, amizade, compreensão e principalmente pela confiança em mim depositada.

Ao Prof. Dr. Cláudio Rosa Gallo, pelos grandes ensinamentos transmitidos, atenção e orientação na etapa microbiológica deste trabalho. 
Ao Prof. Dr. Angelo Pedro Jacomino pelo entusiasmo, consideração, amizade e principalmente por liberar a estrutura de seu laboratório.

À Prof ${ }^{\mathrm{a}}$. Dra. Marlene Schiavinato, pela prontidão e gentileza nas análises via cromatrografia gasosa.

Aos Profs. Dr. Murilo de Melo e Dr. Luiz Antonio Gallo pela liberação do uso de seus laboratórios para realização de algumas análises, além da amizade.

Ao Prof. Dr. Luiz Carlos Basso pela oportunidade de monitoria.

Ao Prof. Dr. Ricardo Ferraz de Oliveira pela consideração e amizade.

A todos os professores do Departamento de Ciências Biológicas pela agradável convivência.

Ao Pesquisador Científico do ITAL/FRUTHOTEC, Dr. José Maria Monteiro Sigrist, por despertar meu interesse na pesquisa desta área e pelo carinho.

Ao Pesquisador Científico da EMBRAPA-Hortaliças, Dr. Celso Luiz Moretti, pela valiosa contribuição ao sugerir esta linha de pesquisa, além de algumas sugestões na redação desta dissertação.

À técnica do Laboratório de Fisiologia e Bioquímica Pós-Colheita, Maria das Graças Ongarelli, pela ajuda nas análises, incentivo e carinho. 
À Cecilia Nogueira, Denise A. L. Baptista e Rose Ocangne, técnicas do Laboratório de Microbiologia de Alimentos, pelo auxílio tão grande nas análises em um ambiente agradável de amizade.

Ao querido amigo de mestrado, Antônio F. C. Amaral, pelo auxílio nas análises no CEBTEC e pela amizade inestimável.

Aos funcionários do Departamento de Produção Vegetal em especial, Aparecido, Barbosa, Chico, D. Helena, Éder, Luciane e Marli pela ajuda nas mais diversas situações.

À Maria Solizéte, secretária do PPG em Fisiologia e Bioquímica de Plantas, pelas inúmeras vezes que me auxiliou.

À Amanda Francine Asega não somente pela grande amizade desenvolvida no mestrado, mas também pela cumplicidade e carinho.

À Marilda Forancelli Carneiro não só pelas palavras amigas, mas também por muitas atitudes que ajudaram na minha vida.

À Juliana Amaral Gobbo, Maristela Paro e Vanessa Weber, amigas do coração. Valeu meninas!

À Eliane Bassetto (Katotinha) pela convivência, apoio e risadas. 
À querida Renatinha (Bulie) que sempre se mostrou muito atenciosa e prestativa em todos os momentos que necessitei.

Aos amigos Alexandre, Cecília, Dani, Edimilson, Elvis, Flávia, Gambé, Josenilda, Liliane, Magali, Míriam (Pri), Raul, Rogerinho, Rosana, Silvana Bortoleto, Silvana Bueno, Vanessa (Unimep) e Virgínia pelo companheirismo.

À Míriam Jaeger Kluge pelas fotos.

Às bibliotecárias Eliana e Silvia, da Divisão de Biblioteca e Documentação da Escola Superior de Agricultura "Luiz de Queiroz" pela atenção dedicada durante a revisão desta dissertação, além da amizade.

A todos, que de alguma forma contribuíram para a realização deste trabalho. 


\section{SUMÁRIO}

Página

RESUMO......

$x$

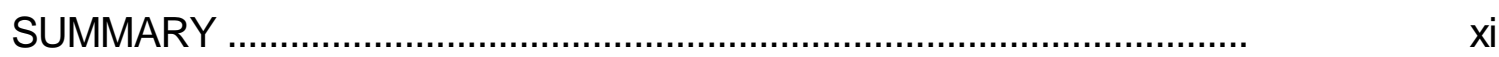

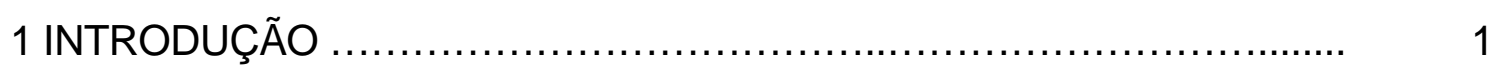

2 REVISÃO DE LITERATURA ............................................. 3

2.1 Generalidades................................................................................

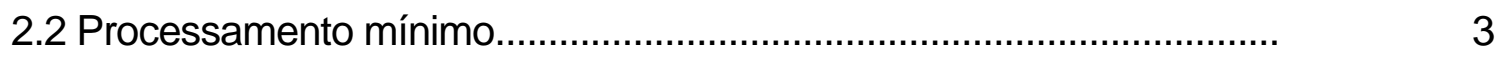

2.3 Fatores que influenciam a qualidade de produtos minimamente

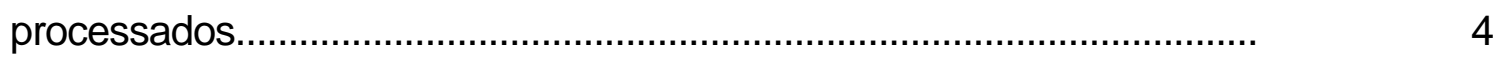

2.3.1 Temperatura.........................................................................

2.3.2 Umidade relativa.......................................................................

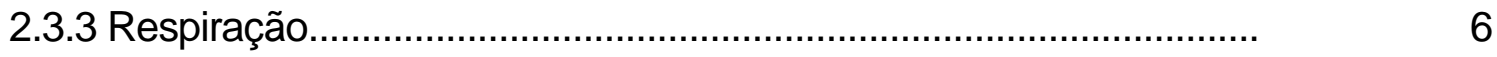

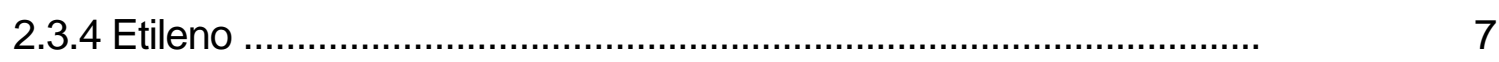

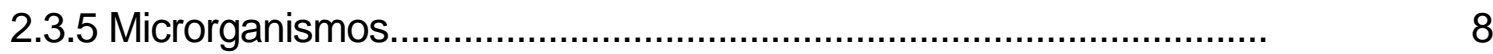

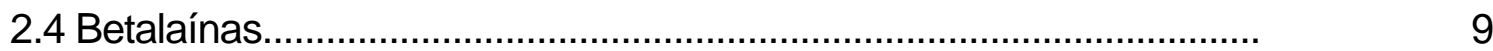

3 ESTUDOS FISIOLÓGICOS E MICROBIOLÓGICOS EM BETERRABAS

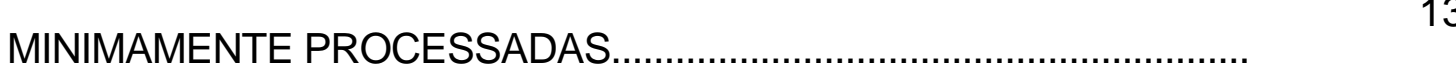

Resumo

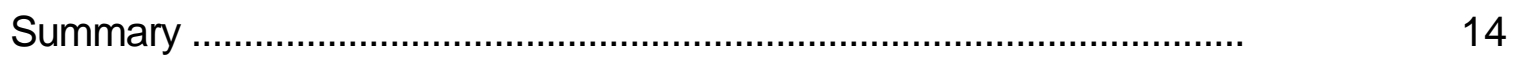

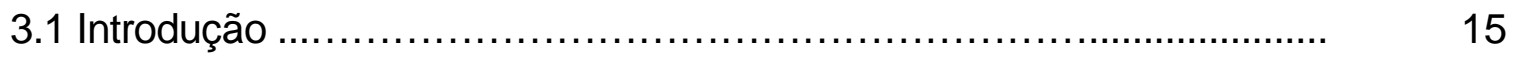

3.2 Material e Métodos ...................................................................... 16

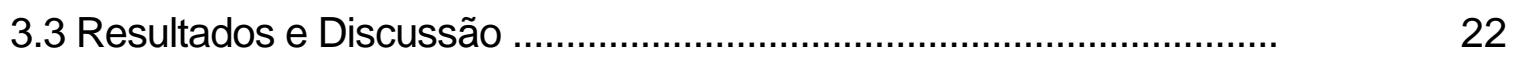

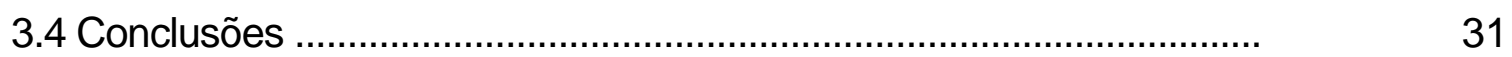


4 ATIVIDADE RESPIRATÓRIA E METABOLISMO DOS PIGMENTOS DE BETERRABAS MINIMAMENTE PROCESSADAS TRATADAS COM ÁCIDO CÍTRICO

Resumo

Summary

4.1 Introdução

4.2 Material e Métodos

4.3 Resultados e Discussão

4.4 Conclusão.

5 TEMPO DE SANITIZAÇÃO PARA BETERRABAS MINIMAMENTE PROCESSADAS

Resumo

Summary

5.1 Introdução

5.2 Material e Métodos.

5.3 Resultados e Discussão

5.4 Conclusão

6 MOMENTO DE SANITIZAÇÃO PARA BETERRBAS MINIMAMENTE

PROCESSADAS.

Resumo......

Summary

6.1 Introdução.

6.2 Material e Métodos.

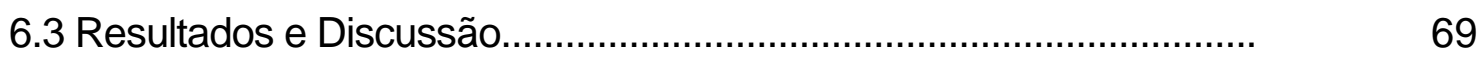

6.4 Conclusão

7 MÉTODOS COMBINADOS DO PROCESSAMENTO MÍNIMO DE BETERRABA.

Resumo..

Summary

7.1 Introdução. 


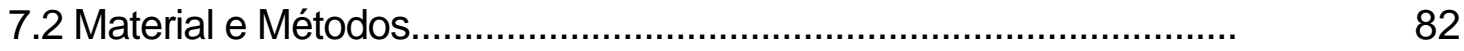

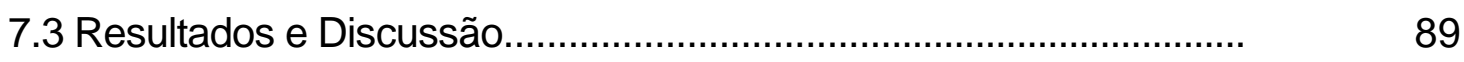

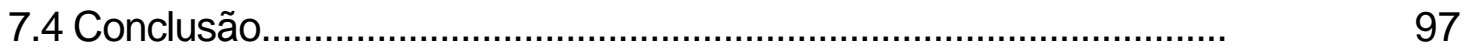

8 CONSIDERAÇÃO FINAL .................................................................... 98

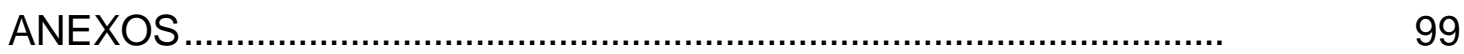

REFERÊNCIAS BIBLIOGRÁFICAS......................................................... 


\title{
ASPECTOS FISIOLÓGICOS, BIOQUÍMICOS E MICROBIOLÓGICOS EM BETERRABAS MINIMAMENTE PROCESSADAS
}

\author{
Autora: MARIA CAROLINA DARIO VITTI \\ Orientador: Prof. Dr. RICARDO ALFREDO KLUGE
}

\section{RESUMO}

Os objetivos deste trabalho foram determinar respostas fisiológicas, bioquímicas e microbiológicas associadas ao processamento mínimo de beterraba e desenvolver um fluxograma de preparo específico para está hortaliça, visando menor perda de qualidade e máxima capacidade de conservação. No primeiro experimento foram estudados alguns aspectos fisiológicos de beterraba intactas, descascadas e raladas e aspectos microbiológicos de beterrabas raladas. Neste experimento foram realizadas análises da taxa respiratória, da produção de etileno e microbiológicas. No segundo experimento foi testado o efeito do ácido cítrico sobre a respiração e pigmentos de betalaínas, determinando-se a taxa respiratória e os teores de betalaínas. No terceiro experimento avaliou-se o tempo de sanitização para beterrabas minimamente processadas, sendo realizadas análises sensoriais, microbiológicas e físico-químicas. No quarto experimento foi estudado 
o momento de sanitização ideal para beterrabas minimamente processadas, sendo também efetuadas análises sensorias, microbiológicas e físico-químicas. E no quinto experimento foi testado o novo fluxograma de preparo, específico para beterrabas minimamente processadas através de métodos combinados, obtidos a partir de resultados dos testes anteriores. Análises sensoriais, microbiológicas e físico-químicas foram realizadas para avaliar o novo fluxograma. A taxa respiratória foi maior para beterrabas raladas. A produção de etileno somente foi detectada em beterrabas raladas. Os resultados das análises microbiológicas estão de acordo com o padrão vigente atualmente. $O$ ácido cítrico reduziu a atividade respiratória e o extravazamento e a degradação dos pigmentos de betalaínas em beterrabas minimamente processadas. $O$ tempo de sanitização de 3 minutos é mais apropridado para manutenção da qualidade. A sanitização apenas após a pelagem é a mais apropriada para manutenção da qualidade, pois reduz a perda de pigmentos e garante um produto com padrões microbiológicos abaixo dos limites permitidos pela Legislação Brasileira, além de evitar o desperdício de cloro. Verificou-se pelo novo fluxograma de preparo que as beterrabas minimamente processadas tem um período de comercialização viável por 10 dias. O novo fluxograma desenvolvido é mais indicado para manutenção da qualidade por reduzir perda de pigmentos, reduzir a taxa respiratória e garantir a segurança alimentar do produto. 


\title{
PHYSIOLOGICAL, BIOCHEMICHAL AND MICROBIOLOGICAL ASPECTS OF FRESH-CUT BEET ROOTS
}

\author{
Author: MARIA CAROLINA DARIO VITTI \\ Adviser: Prof. Dr. RICARDO ALFREDO KLUGE
}

\section{SUMMARY}

The purposes of this work were to determine the physiological, biochemical and microbiological responses to minimal processing of beet roots and to develop a preparation flowchart for this vegetable, aiming at lowering quality losses and maximizing preservation. Some physiological aspects of whole, peeled and grated beet roots, as well as microbiological aspects of grated beet roots were studied in the first experiment. Analyses of respiratory rate, ethylene production and microbiology were carried out in this experiment. In the second experiment, respiratory rates and betalain amounts were determined to evaluate the effects of citric acid on respiration and betalain pigments. In a third experiment, the sanitization time for minimally processed beet roots was evaluated and sensory, microbiological and physicochemical analyses were carried out. In a fourth experiment, the ideal sanitization time for minimally processed beet roots was determined and sensory, microbiological and physicochemical analyses were carried out. In a fifth experiment, a specific new procedures flowchart was tested for the minimal processing of beet roots 
using a combination of methods based on previous experiments. Sensory, microbiological and physicochemical analyses were conducted to evaluate the new procedures flowchart. The respiratory rate was higher in grated beet root. Ethylene production was detected only in grated beet roots. The microbiological results were in accordance with the current standard. Citric acid reduced the respiratory activity, betalain exudation and degradation in minimally processed beet roots. A three-minute sanitization showed to be the most suitable for quality maintenance. Sanitization alone after pealing is appropriate for quality maintenance, as it decreases pigment losses, prevents wasteful use of chlorine and ensures microbiological standards to be in accordance with the Brazilian Legislation. Minimally processed beet root produced by the new procedures flowchart are suitable for commercialization for 10 days. The new procedures flowchart is especially recommended for quality maintenance, once it decreases pigment loss and the respiratory rate, and ensures good food-safety standards for the product. 


\section{INTRODUÇÃO}

Nos últimos anos tem sido enfatizado a necessidade de consumo de frutas e hortaliças frescas, buscando-se uma dieta mais saudável ao mesmo tempo em que há uma demanda crescente de alimentos mais convenientes, frescos, menos processados e prontos para o consumo. A indústria de alimentos tem respondido a essa demanda como o desenvolvimento dos produtos minimamente processados. Essa tecnologia emergente visa satisfazer a necessidade do consumo de frutas e hortaliças frescas, saudáveis e com qualidade nutricional, sensorial e microbiológica (Vanetti, 2000).

$\mathrm{O}$ aumento da demanda por produtos minimamente processados traz consigo grandes desafios no que se refere ao desenvolvimento de tecnologias de armazenamento. Esses produtos apresentam maior taxa de deterioração do que o produto inteiro, considerando que, com o corte, os tecidos internos do vegetal são expostos e o metabolismo é acelerado. Adicionalmente, os tecidos ficam mais suscetíveis à contaminação microbiana, aumentando os riscos de toxinfecção alimentar, caso não sejam tomadas medidas preventivas.

Devido a sua alta perecibilidade, os produtos minimamente processados são comercializadas, de maneira geral, no período de, no máximo, 5 dias. $\mathrm{O}$ aumento da vida pós-colheita destes produtos para 10 dias traria grande benefícios para o mercado, possibilitando maior expansão e flexibilidade de comercialização, além da redução de perdas. Para que isso seja alcançado, extensivos trabalhos de pesquisa devem ser realizados, buscando desenvolver tecnologias de armazenamento que permitam aumentar a conservação dos produtos minimamente processados, com menor perda de qualidade. 
A beterraba é uma hortaliça que tem apresentado grande expansão no mercado de minimamente processado. Entretanto, tem sido observada elevada perda de qualidade em função da descoloração da superfície das raízes minimamente processadas e da elevada desidratação. Os processos de lavagem e enxague, realizados após o corte do produto, têm favorecido a perda dos pigmentos de betalaínas; Adicionalmente, o corte favorece o extravazamento do suco celular para o exterior, ocasionando a desidratação do produto.

Para prolongar a vida útil dos produtos minimamente processados, são necessários estudos referentes aos efeitos fisiológicos e qualitativos causados pelo processamento mínimo, principalmente relacionados à taxa respiratória e produção de etileno. Estes estudos visam obter conhecimentos básicos importantes para a seleção e desenvolvimento de tecnologias de armazenamento e embalagem para os produtos minimamente processados. Aliando a isso, os impactos do processamento mínimo sobre o crescimento de microrganismos indesejáveis também devem ser avaliados.

Em beterraba, o fluxograma de preparo do produto deve ser melhor estudado, buscando identificar pontos passíveis de manipulação, promovendo menor perda de qualidade, manutenção da segurança alimentar e aumento de conservação.

Desta forma, os objetivos deste trabalho foram:

- Determinar respostas fisiológicas, bioquímicas e microbiológicas associadas ao processamento mínimo de beterraba;

- Desenvolver um fluxograma de preparo específico para beterraba minimamente processada, visando menor perda de qualidade e máxima capacidade de conservação. 


\section{REVISÃO DE LITERATURA}

\subsection{Generalidades}

A beterraba pertence a família Chenopodiaceae na qual a parte comestível é a sua raiz tuberosa. Esta hortaliça tuberosa tem uma típica coloração vermelho-escuro, devido aos pigmentos de betalaínas.

A beterraba é nativa da Europa, Norte da África e oeste da Ásia. É bastante cultivada nos países de clima temperado. No Brasil é mais cultivada nos estados de São Paulo, Minas Gerais e na região Sul (Camargo, 1981).

Há poucas cultivares plantadas no Brasil, sendo a maioria delas de origem européia. A tradicional cultivar Early Wonder tornou-se padrão de qualidade.é precoce, com raízes globulares e de coloração púrpura (Filgueira, 2000).

\subsection{Processamento mínimo}

O consumo de produtos minimamente processados tem tido considerável aumento nos últimos anos, em função do maior interesse dos consumidores por produtos cada vez mais naturais e convenientes (Durigan \& Sargent, 1999), e também pela maior participação da mulher no mercado de trabalho, envelhecimento da população e aumento na importância das refeições coletivas (Moretti, 2001).

Wiley (1994) definiu os produtos minimamente processados como sendo aqueles preparados através de uma ou várias operações apropriadas, tais como descascamento, fatiamento, picamento e conservação através de tratamentos preservativos isolados ou combinados. Almeida (1998) aponta o processamento mínimo como uma série de operações para a obtenção de um 
produto que ofereça conveniência de uso e características semelhantes æ̀̀ do vegetal in natura.

Hortaliças minimamente processadas são mais perecíveis do que quando intactas, porque são submetidas a severos estresses físicos advindos principalmente do descascamento e corte. Estes danos mecânicos aumentam o metabolismo dos produtos, com o consequente aumento da taxa de deterioração (Rosen \& Kader, 1989).

A durabilidade de um produto minimamente processado é extremamente baixa se comparada ao produto inteiro, considerando que nas superfícies do corte, as células e a membrana celular são destruídas e ocorre alteração no metabolismo celular. A injúria causada pelo corte promove aumento na produção de etileno e na taxa respiratória, favorecendo, assim, a rápida senescência.

Mesmo os órgãos de reserva, como raízes, bulbos, rizomas e tubérculos, que naturalmente possuem uma vida pós-colheita relativamente longa quando submetidos ao processamento mínimo, passam a ser altamente perecíveis, com uma vida de prateleira muito curta (Kasmire \& Cantwell, 1992).

\subsection{Fatores que influenciam a qualidade de produtos minimamente processados}

\subsubsection{Temperatura}

O controle da temperatura é o fator mais importante para minimizar os efeitos dos ferimentos aos tecidos nos produtos minimamente processados (Kader, 1992; Brecht, 1995). Para estes produtos, a cadeia de frio deve começar, preferencialmente, logo após a colheita, pois o pré-resfriamento da matéria prima prolonga a vida útil dos mesmos (Wiley, 1994). Esta diminuição na temperatura aumenta a vida útil dos produtos, uma vez que retarda os processos fisiológicos dos mesmos (Wills et al., 1981). 
A utilização do armazenamento refrigerado para frutas e hortaliças minimamente processadas se baseia na idéia de que as baixas temperaturas retardam o crescimento da maioria dos microrganismos e são eficazes para reduzir as atividades enzimáticas (Wiley, 1994).

Baixas temperaturas, durante 0 armazenamento, retardam 0 metabolismo do vegetal através da diminuição de sua taxa respiratória e da redução de sua atividade enzimática (Chitarra \& Chitarra, 1990). Dentro da variação fisiológica de cada espécie, a taxa respiratória, normalmente aumenta com a elevação da temperatura, principalmente na faixa de $5^{\circ} \mathrm{C}$ a $20^{\circ} \mathrm{C}$ (Chitarra \& Alves, 2001).

Temperaturas superiores a $10^{\circ} \mathrm{C}$ promovem um incremento muito rápido na concentração de $\mathrm{CO}_{2}$ dentro das embalagens, devido a aumento na atividade metabólica e no crescimento microbiano (Wiley, 1994).

\subsubsection{Umidade Relativa}

A perda de água é uma das principais causas de deterioração de frutas e hortaliças após a colheita.

As frutas e hortaliças possuem, em seus espaços intercelulares aproximadamente $100 \%$ de água, sendo que a tendência é, quase sempre, de o vapor d'água escapar destes espaços para o ambiente, por transpiração. Este processo ocorre porque a umidade relativa do ambiente onde se encontram é frequentemente menor que 100\% (Hardenburg et al., 1986).

As hortaliças minimamente processadas apresentam maior relação superfície/ volume do que quando inteiras, favorecendo ainda mais a perda de água de seus tecidos. Um exemplo típico é o caso de cenoura minimamente processada, cuja principal causa de sua deterioração é a perda de turgidez, portanto, de textura, e o aparecimento da coloração branca em sua superfície. Os consumidores associam a perda de textura e a coloração branca ao envelhecimento do produto, e alguns pesquisadores, à desidratação de superfícies que sofreram algum tipo de abrasão (Tatsumi et al., 1991). 


\subsubsection{Respiração}

A conservação de hortaliças minimamente processadas é um processo especialmente complexo, do qual participam as células vegetais danificadas, as intactas e as inativadas. Em outras palavras, algumas células se encontram respirando em velocidade normal, enquanto que as danificadas respiram a velocidades maiores (Rolle \& Chism, 1987).

O efeito do corte e outras injúrias, provocadas durante as etapas do processamento mínimo, tem como consequência o rompimento de organelas, modificação da permeabilidade da célula, desorganização celular, ativação da síntese do etileno e aumento na respiração (Chitarra, 1998).

A ascensão respiratória caracteriza-se pelo aumento no consumo de $\mathrm{O}_{2}$ e na liberação de $\mathrm{CO}_{2}$ (Yang, 1985). A taxa respiratória, além de servir como indicador da atividade metabólica, é útil para a determinação da vida útil no armazenamento (Glenn et al., 1988).

O controle da respiração é fundamental para os produtos minimamente processados, o que obriga a sua comercialização sob refrigeração. Segundo Cantwell (1992), a taxa respiratória dos produtos minimamente processados é muitas vezes superior ao do produto inteiro.

A conservação de um produto está diretamente relacionada com a taxa respiratória, sendo que a perecibilidade de um produto é diretamente proporcional à sua atividade respiratória. Os produtos minimamente processados são mais perecíveis que tecidos intactos. Portanto, tratamentos que reduzam a respiração são importantes para aumento na vida útil destes produtos. Kato-Noguchi \& Watada (1997) observaram que a taxa respiratória de cenouras minimamente processadas foi substancialmente reduzida com a aplicação do ácido cítrico. O ácido cítrico está envolvido na inibição da enzima 
fosfofrutoquinase que catalisa a fosforilação da frutose 6-fosfato em 1,6bifosfato na via glicolítica do metabolismo respiratório.

\subsubsection{Etileno}

O etileno $\left(\mathrm{C}_{2} \mathrm{H}_{4}\right)$ é um fitohormônio que está envolvido na aceleração do amadurecimento e senescência de frutos climatéricos. Este fitohormônio, encontrado nos espaços intercelulares, tem como precursor primário o aminoácido metionina, como intermediário o SAM (S-adenosilmetionina) e como precursor imediato o ACC (ácido aminociclopropano carboxílico). A enzima ACC sintase catalisa a reação de formação do ACC a partir do SAM, e a enzima ACC oxidase oxida o ACC formando o etileno (Yang, 1985).

O mecanismo de ação do etileno consiste na sua ligação a uma molécula receptora, provavelmente uma proteína, que possui um sítio de ligação do fitohormônio. A ativação do mesmo segue através de dois passos possíveis: 0 próprio receptor ativa o fitohormônio ou, o que parece mais provável, uma via de sinalização formada por mensageiros secundários vai ao núcleo da célula e induz a expressão gênica (transcrição). Consequentemente há formação de novos RNAs e novas proteínas, desencadeando uma série de respostas inerentes ao etileno, como o amadurecimento e senescência de frutos (Burg \& Burg, 1967; Lelièvre et al., 1997; Kluge et al., 2002).

A síntese do etileno pode ser induzida por fatores externos como elevação da temperatura e injúrias mecânicas, promovendo sua atuação em sítios específicos nas células, usualmente ativando ou inibindo enzimas do ciclo metabólico dos tecidos. O etileno contribui para biossíntese de enzimas envolvidas em alterações bioquímicas e fisiológicas (Brecht, 1995).

De acordo com Sakr et al. (1997), o aumento da produção de etileno pode ser uma resposta hormonal e bioquímica devido ao estresse causado pelo corte. Isto ocorre pois o primeiro alvo desse estresse é a membrana plasmática, a qual responde com mudanças em suas características físicas, de forma a 
contornar tais perturbações e tentar reparar os danos causados durante o processamento.

A lesão dos tecidos de um vegetal provoca a perda ou redução da compartimentação celular (aumento da permeabilidade das membranas), o que ativa o sistema gerador de etileno, estimulando sua síntese, algumas vezes em poucos minutos. O etileno produzido em decorrência da lesão, também denominado de "etileno de ferida" acelera a deterioração e a senescência dos tecidos vegetais (Brecht, 1995).

\subsubsection{Microrganismos}

O processamento mínimo favorece a contaminação de alimentos por microrganismos deterioradores e patogênicos, em razão do manuseio e do aumento das injúrias nos tecidos (Wiley, 1994), o contrário do que ocorre com as frutas e hortaliças intactas, que são parcialmente protegidas da invasão microbiana pela casca (Shewfelt, 1987).

A contagem dos microrganismos psicrotróficos permite avaliar as condições microbiológicas do processamento de alimento refrigerado. Números elevados normalmente diminuem seu tempo de vida útil (Hajdenwurcel, 1998).

De acordo com Nguyen \& Carlin (1994), tem sido encontrado em produtos minimamente processados um grande número de microrganismos, incluindo leveduras, coliformes, coliformes fecais, microbiotas mesofílicas, bolores, etc. Estes autores afirmam que um bom controle da temperatura de armazenamento, desinfecção química e uso de atmosfera modificada diminuem consideravelmente o desenvolvimento destes microrganismos.

Amostras de hortaliças minimamente processadas, desde a produção até a distribuição ao nível do consumidor, devem sofrer análises microbiológicas freqüentes. É importante também a sanitização de toda a planta de processamento, inclusive dos instrumentos e equipamentos utilizados, bem como a utilização de luvas, máscaras, aventais e botas por parte dos 
operadores, o uso de água clorada para a lavagem das hortaliças e um controle bastante rigoroso da temperatura (Sigrist, 1998).

Hiraushi \& Horie (1982) afirmam que os coliformes são bons indicadores de contaminação fecal em alimentos. De acordo com a Internacional Commission on Microbiological Specifications for Foods - ICMSF (1978), a

presença de coliformes em alimentos indica manipulação inadequada durante o processamento, uso de equipamentos em más condições sanitárias ou ainda utilização de matéria-prima contaminada.

De acordo com a Resolução RDC oo 12 de 02/01/01, da Agência Nacional de Vigilância sanitária (ANVISA) do Ministério da Saúde, a legislação sanitária de alimentos exige para hortaliças in natura ausência de Salmonella (em $25 \mathrm{~g}$ de amostra), e de, no máximo, $10^{2} \mathrm{NMP}$ de coliformes fecais $/ \mathrm{g}$ de produto para a preservação da saúde pública.

Segundo Pilon et al. (2002), o resultado das análises microbiológicas para amostras de cenouras minimamente processadas foi negativo para coliformes fecais e Salmonella durante todo o armazenamento, sendo que somente as bactérias psicrotróficas apresentaram aumento de crescimento.

Vanetti (2000) comenta que o prolongamento da vida útil dos produtos minimamente processados é dependente, além do retardamento dos processos fisiológicos, do retardamento da proliferação microbiana, o que garante a segurança e a aceitabilidade dos mesmos. Neste aspecto, a higienização e o controle das condições de armazenamento desempenham papel fundamental no controle do crescimento microbiano.

\subsection{Betalaínas}

A cor é o atributo de qualidade mais atrativo para o consumidor. Os produtos com coloração forte são os preferidos, embora, na maioria dos casos, a cor não se correlacione nem com o valor nutritivo e nem com a qualidade comestível do produto (Chitarra \& Alves, 2001). 
De acordo com Kays (1991), a coloração é o principal parâmetro de qualidade, pois os consumidores já desenvolveram uma relação positiva entre a cor e a qualidade máxima do produto.

O uso de baixas temperaturas de armazenamento para os produtos minimamente processados reduzem a degradação da coloração dos tecidos vegetais lesionados (Wiley, 1994).

As betalaínas são os pigmentos encontrados nos tecidos de beterraba. Este grupo de pigmentos são semelhantes em seu aspecto visual com antocianinas e flavonóides. Foram denominadas incorretamente, na bibliografia antiga, por antocianinas que continham nitrogênio. Encontram-se presentes somente em 10 famílias da ordem Centrospermae. São compostos hidrossolúveis e estão divididas em duas classes: betacianina (responsável pela coloração avermelhada) e betaxantina (responsável pela coloração amarelada), caracterizando a coloração típica das raízes de beterraba (Fenena, 1995).

Cerca de 70 betalaínas são conhecidas e todas possuem a mesma estrutura básica (Figura 1), em que R ou R' podem ser hidrogênio ou compostos aromáticos, respectivamente. A cor é atibuída às estruturas de ressonância: se R ou R' não permitem ressonância, o composto é chamado de betaxantina; se $R$ ou R' permitem ressonância, o composto é chamado de betacianina (Bobbio \& Bobbio, 1984). 


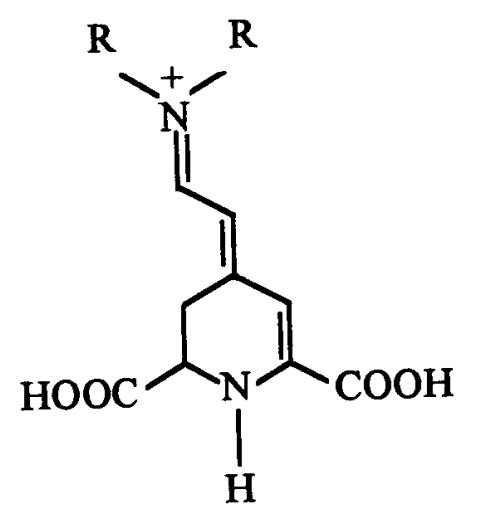

Figura 1 - Estrutura básica da betalaína.

Estes pigmentos, além de fornecerem cor à beterraba, são importantes substâncias antioxidantes para a dieta humana (Kanner et al., 2001).

Poucos estudos referente aos teores de pigmentos em beterraba são encontrados na literatura. Sapers \& Hornstein (1979) verificaram diferenças significativas no conteúdo de betacianina e betaxantina em diferentes variedades de beterraba de mesa. De acordo com Nilson (1973), o teor de betacianina e betaxantina varia em função da cultivar. Segundo o autor, os teores de betacianina e betaxantina para beterrabas intactas, podem variar de 45-210 e 20-140mg 100 ${ }^{-1}$, respectivamente.

Osornio \& Chaves (1998) verificaram, em beterrabas raladas e armazenadas a $0^{\circ} \mathrm{C}$, que o teor de betalaína decresceu aproximadamente 40 $50 \%$ após 7 dias.

Os pigmentos de betalaínas são mais solúveis em água do que em álcool (Nilson, 1970). No caso de beterrabas minimamente processadas, os processos de sanitização e enxagüe favorecem uma maior perda destes pigmentos devido o contato da superfície das raízes com a água.

Salgado (1997) observou que a adição de antioxidante, como o ácido ascórbico, melhora a estabilidade dos pigmentos de betalaínas em beterraba, 
sendo que a concentração de $400 \mathrm{mg} \mathrm{L}^{-1}$ foi a melhor para preservar da cor do produto. $\mathrm{O}$ ácido cítrico teve semelhante efeito protetor quando comparado com o ácido ascórbico em beterrabas. Ambos os ácidos usados em combinação não obtiveram efeito maior do que quando utilizados isoladamente (Attoe \& Elbe, 1985). 


\section{ESTUDOS FISIOLÓGICOS E MICROBIOLÓGICOS EM BETERRABAS MINIMAMENTE PROCESSADAS}

\section{Resumo}

O presente experimento teve como objetivo avaliar a taxa respiratória e a produção de etileno em beterrabas minimamente processadas, intactas e descascadas. Determinou-se também alguns aspectos microbiológicos de beterrabas minimamente processadas durante $\mathrm{o}$ armazenamento refrigerado. $\mathrm{A}$ taxa respiratória e a produção de etileno foram avaliadas até 4 horas após 0 processamento e durante 10 dias de armazenamento a $5^{\circ} \mathrm{C}$. As análises microbiológicas foram realizadas no dia do processamento e após 10 dias de conservação. Raízes intactas apresentaram a menor taxa respiratória $(5 \mathrm{~mL} \mathrm{CO} 2$ $\mathrm{kg}^{-1} \mathrm{~h}^{-1}$ ), enquanto que beterrabas raladas e descascadas apresentaram taxa respiratória de $30 \mathrm{~mL} \mathrm{CO}_{2} \mathrm{~kg}^{-1} \mathrm{~h}^{-1}$ após 4 horas do processamento. Beterrabas minimamente processadas apresentaram um pico respiratório no $2^{0}$ dia de armazenamento ( $\left.80 \mathrm{~mL} \mathrm{CO}_{2} \mathrm{~kg}^{-1} \mathrm{~h}^{-1}\right)$, estabilizando em $30 \mathrm{~mL} \mathrm{CO}_{2} \mathrm{~kg}^{-1} \mathrm{~h}^{-1}$ no $4^{\circ}$ dia. Não foi detectado etileno em beterrabas intactas e descascadas enquanto que, para beterrabas minimamente processadas, a produção de etileno nas primeiras horas após o corte atingiu $0,90 \mu \mathrm{L} \mathrm{C}_{2} \mathrm{H}_{4} \mathrm{~kg}^{-1} \mathrm{~h}^{-1}$, havendo pouca variação ao longo das 4 horas de avaliação e durante o período de armazenamento a $5^{\circ} \mathrm{C}$. As contagens de bactérias psicrotróficas e coliformes totais mantiveram-se dentro dos limites aceitáveis, e não foi detectada presença de coliformes fecais e Salmonella. 
Palavras-chave: Beta vulgaris L., processamento mínimo, respiração, etileno, microbiologia.

\section{PHYSIOLOGICAL AND MICROBIOLOGICAL STUDIES ON MINIMALLY PROCESSED BEET ROOTS}

\section{Summary}

The purpose of the present work was to evaluate the respiratory rate and ethylene production of whole or peeled minimally processed beet root. Some microbiological aspects of minimally processed beet root during refrigerated storage were studied. The respiratory rate and ethylene production were evaluated up to 4 hours after processing and during 10 days of storage at $5^{\circ} \mathrm{C}$. Microbiological analyses were carried out at the same day of processing and after 10 days of storage. Whole beet roots showed the lowest respiratory rate $\left(5 \mathrm{~mL} \mathrm{CO} \mathrm{kg}^{-1} \mathrm{~h}^{-1}\right)$, while grated and peeled beet roots showed a $30 \mathrm{~mL} \mathrm{CO}_{2} \mathrm{~kg}^{-1}$ $\mathrm{h}^{-1}$ respiratory rate 4 hours after processing. Minimally processed beet root presented a respiratory peak $\left(80 \mathrm{~mL} \mathrm{CO}_{2} \mathrm{~kg}^{-1} \mathrm{~h}^{-1}\right)$ on the second day of storage, which stabilized at $30 \mathrm{~mL} \mathrm{CO}_{2} \mathrm{~kg}^{-1} \mathrm{~h}^{-1}$ on the fourth day of storage. Ethylene was not detected in whole or peeled beet roots, while ethylene production in minimally processed beet roots reached $0,90 \mu \mathrm{L} \mathrm{C}_{2} \mathrm{H}_{4} \mathrm{~kg}^{-1} \mathrm{~h}^{-1}$ during the first hours after cutting, with little variation throughout the 4 hour evaluation period and during storage at $5^{\circ} \mathrm{C}$. Psychotropic bacteria and total coliforms counts were within acceptable limits and no fecal coliforms or Salmonella were detected.

Key-words: Beta vulgaris L., fresh-cut, respiration, ethylene, microbiology. 


\subsection{Introdução}

O processamento mínimo é definido como qualquer alteração física causada em frutos ou hortaliças que mantém o estado fresco desses produtos. Inclui as operações de seleção, lavagem, corte, sanitização, centrifugação, embalagem, armazenamento e comercialização (IFPA, 1999; Moretti, 1999).

As frutas e as hortaliças minimamente processadas mantém seus tecidos vivos, porém não exibem a mesma resposta fisiológica que um tecido inteiro (Wiley, 1994). Estes produtos são mais perecíveis do que quando intactos, considerando que são submetidos a severos estresses físicos, advindos, principalmente, do descascamento e do corte. Esses danos mecânicos aumentam o metabolismo, com conseqüente aumento da taxa respiratória e da síntese de etileno, causando maior velocidade de deterioração. O etileno proveniente do corte ("etileno de ferida") contribui para a biossíntese de enzimas envolvidas em alterações fisiológicas e bioquímicas associadas à senescência (Brecht, 1995).

A injúria mecânica causada pelo corte ou descascamento é um dos maiores obstáculos para a conservação dos produtos minimamente processados, sendo que a taxa respiratória desses produtos é muitas vezes superior que a de órgãos intactos (Cantwell, 1992).

Mesmo os órgãos de reserva, como raízes, bulbos, rizomas e tubérculos, que naturalmente possuem uma vida pós-colheita relativamente longa quando submetidos ao processamento mínimo, passam a ser altamente perecíveis, com uma vida de prateleira muito curta (Kasmire \& Cantwell, 1992).

Adicionalmente, o processamento mínimo favorece a contaminação por microrganismos deterioradores e patogênicos, em razão do manuseio excessivo e do aumento das injúrias nos tecidos (Wiley, 1994), o contrário do que ocorre com as frutas e hortaliças intactas, que são parcialmente protegidas da invasão microbiana pela casca (Shewfelt, 1987). 
Vários trabalhos na literatura relatam estudos referentes ao metabolismo de diversas frutas e hortaliças minimamente processadas. Entretanto, pouco é contemplado sobre beterrabas (Osornio \& Chaves, 1998) minimamente processadas.

Assim, o objetivo deste estudo foi o de verificar os aspectos fisiológicos e microbiológicos associados ao processamento mínimo de beterraba.

\subsection{Material e Métodos}

\section{Obtenção do material experimental}

As beterrabas, cv. Early Wonder, colhidas na região de Piracicaba-SP, foram levadas para o Laboratório de Pós-Colheita do Departamento de Produção Vegetal da ESALQ/USP onde foram selecionadas quanto ao tamanho, firmeza, cor e formato, tendo sido descartadas raízes murchas, e com defeitos e injúrias. Estas foram pré-lavadas em água corrente com o objetivo de retirar as impurezas advindas do campo (vide ANEXO A). A seguir, o material experimental foi separado em três lotes, sendo que dois deles foram minimamente processados e o outro permaneceu intacto.

\section{Processamento mínimo}

As etapas de processamento mínimo ocorreram dentro da câmara fria $\left(10 \pm 1^{\circ} \mathrm{C}\right)$ sobre mesa de aço inoxidável devidamente higienizada. Os operadores utilizaram roupas protetoras (botas, aventais, luvas, máscaras e toucas), como parte das condições mínimas de assepsia.

Um lote foi apenas descascado e o outro lote sofreu, além do descascamento, o corte em retalhos.

As etapas de processamento mínimo constaram de: 
a) Descascamento: $O$ produto foi descascado mecanicamente por descascadora industrial (Shymsen) com disco abrasivo para retirada da película externa das raízes.

b) Lavagem e pré-resfriamento: as raízes foram imersas em água resfriada $\left(5 \pm 0,5{ }^{\circ} \mathrm{C}\right)$ por 2 minutos. A função desta imersão em água resfriada foi a de manter a atividade metabólica do produto baixa.

c) Corte: as beterrabas foram submetidas a etapa de corte em forma de retalhos. Utilizou-se uma processadora industrial (Robot Coupe) com disco de espessura de $2 \mathrm{~mm}$.

d) Sanitização: Após o corte, o material foi sanitizado via imersão por 6 minutos em água clorada (200ppm de cloro ativo), com o objetivo de reduzir riscos de contaminação. O sanitizante utilizado foi o SUMAVEG, este produto tem como princípio ativo o Dicloro-S-Triazinatriona Sódica Diidratada e é fabricado pela Diversey Lever-Indústrias Gessy Lever Ltda.

e) Enxague: as raízes foram enxaguadas através de imersão por 1 minuto (em água com 3ppm de cloro ativo) para a retirada do excesso de cloro. O mesmo sanitizante foi utilizado.

f) Centrifugação: realizada em centrífuga doméstica (ARNO) durante 1 minuto para a retirada do excesso de água do produto, com velocidade de 2000rpm.

g) Armazenamento: as raízes foram armazenadas a $5 \pm 1^{\circ} \mathrm{C}$ e $85 \pm 5 \%$ UR durante 10 dias, em bandejas de poliestireno expandido, com dimensões $14 \times 20 \mathrm{~cm}$ de largura e comprimento, respectivamente, envoltas em filmes de PVC (policloreto de vinila) com $14 \mu \mathrm{m}$ de espessura.

\section{Determinações}

Taxa respiratória

As raízes (intactas, descascadas e raladas) foram acondicionadas em jarros de vidro $(600 \mathrm{~mL})$ hermeticamente fechados durante 1 hora $\mathrm{e}$ armazenadas a temperatura de $5 \circ \mathrm{C}$. Na tampa dos frascos foi colocado um 
septo de silicone através do qual foi retirado uma alíquota da atmosfera interna dos frascos $(2 \mathrm{~mL})$ e medido o conteúdo de $\mathrm{CO}_{2}$ em um analisador de gases PBI Dansensor 9900. Os resultados expressos em $\% \mathrm{CO}_{2}$ foram utilizados para cálculo da taxa respiratória levando-se em consideração o volume do frasco, a massa das beterrabas e o tempo que o frasco permaneceu fechado. A cada hora, durante um período de 4 horas, foi retirada uma amostra da composição gasosa do interior dos jarros e mediu-se a evolução de $\mathrm{CO}_{2}$. Posteriormente, as leituras foram realizadas a cada 2 dias durante 10 dias somente para beterrabas raladas. Os resultados foram expressos em $\mathrm{mL} \mathrm{CO}_{2} \mathrm{~kg}^{-1} \mathrm{~h}^{-1}$.

Produção de etileno

O procedimento para determinação da taxa de produção de etileno foi semelhante ao utilizado para determinação da taxa respiratória. A taxa de síntese de etileno foi obtida retirando-se com auxílio de uma seringa uma alíquota de 0,5 mL de amostra da composição gasosa do interior dos jarros e injetada em cromatógrafo a gás (Shimadzu GC 14-B) com detector de ionização de chama, utilizando-se uma coluna "HayeSep T". O gás de arraste foi o nitrogênio, a um fluxo de $20 \mathrm{~mL}^{\text {minuto }}{ }^{-1}$. As temperaturas mantidas no aparelho foram de $80^{\circ} \mathrm{C}$ para a coluna, $100^{\circ} \mathrm{C}$ no injetor e $150^{\circ} \mathrm{C}$ no detector. Como padrão foi utilizado etileno puro $\left(1 \mu \mathrm{L} \mathrm{C}_{2} \mathrm{H}_{4} \mathrm{~kg}^{-1} \mathrm{~h}^{-1}\right)$, da White Martins. Os resultados foram expressos em $\mu \mathrm{L} \mathrm{C}_{2} \mathrm{H}_{4} \mathrm{~kg}^{-1} \mathrm{~h}^{-1}$.

\section{Análises microbiológicas}

As análises microbiológicas foram realizadas no dia do processamento e no $10^{\circ}$ dia de armazenamento somente para beterrabas raladas.

A microbiota contaminante da beterraba minimamente processada foi avaliada pela contagem total de bactérias psicrotróficas, número mais provável (NMP) de coliformes totais e fecais e presença/ausência de Salmonella.

As análises para contagem de bactérias psicrotróficas e para o NMP de coliformes foram efetuadas em porções de $20 \mathrm{~g}$ de raízes para cada repetição, 
pesadas assepticamente e colocadas em erlenmeyers, com $180 \mathrm{~mL}$ de água peptonada $(0,1 \%)$ estéril, constituindo a diluição $10^{-1}$. A partir da diluição $10^{-1}$, obteve-se a diluição $10^{-2}$, pipetando-se $10 \mathrm{~mL}$ da solução $10^{-1} \mathrm{em} 90 \mathrm{~mL}$ de água peptonada esterilizada $(0,1 \%)$ e a partir desta, obteve-se a diluição $10^{-3}$.

A determinação da presença de Salmonella foi a única análise que dispensou o uso de diluições, por ter sido empregada uma metodologia distinta (descrita posteriormente).

a) Contagem total de bactérias psicrotróficas

Para contagem de bactérias psicrotróficas (qualquer bactéria cujo ótimo de temperatura para crescimento situa-se acima de $20^{\circ} \mathrm{C}$, porém toleram e crescem sob refrigeração), utilizou-se o meio Ágar Padrão para Contagem (PCA).

O princípio desta metodologia baseia-se na capacidade que cada célula microbiana presente na amostragem, tem de formar uma colônia visível e isolada, uma vez fixada em um meio de cultura sólido próprio para seu desenvolvimento (Silva et al., 2001).

A partir da diluição $10^{-1}$ até a $10^{-3}$ das beterrabas minimamente processadas, foram plaqueados em profundidade, $1 \mathrm{~mL}$ de cada diluição em duplicata, utilizando-se $20 \mathrm{~mL}$ de meio de cultivo PCA. Após o plaqueamento, as placas permaneceram em repouso até completa solidificação do meio, sendo, então invertidas e incubadas a $7^{\circ} \mathrm{C}$ por 10 dias (vide ANEXO C).

Decorrido o tempo de incubação foram selecionadas as placas e fez-se a contagem das mesmas, com auxílio do contador de colônias tipo Quebec. 
b) NMP de coliformes totais e fecais

Coliformes totais e fecais foram determinados pelo método do NMP, através da técnica dos Tubos Múltiplos ( vide ANEXO D).

A técnica de Tubos Múltiplos conta com duas fases distintas: a fase do teste presuntivo, onde se busca detectar a presença de microrganismos fermentadores de lactose e onde é possível recuperar células injuriadas e a fase do teste confirmativo, através do qual se determina a população real de coliformes totais e fecais.

Para o teste presuntivo foram utilizadas séries de três tubos de ensaio, os quais continham um tubo de Durham e Caldo Lactosado (CL), um meio cuja fonte de carbono é a lactose que é fermentada pelas bactérias do grupo coliforme, com produção de ácido e gás.

A primeira série contou com tubos contendo o meio em dupla concentração, uma vez que, nessa série, foram adicionados $10 \mathrm{~mL}$ do inóculo, da diluição $10^{-1}$, evitando-se assim, uma diluição excessiva do caldo (meio de cultivo). As demais séries continham CL em concentração normal, sendo que em cada tubo da segunda série, adicionou-se $1 \mathrm{~mL}$ da diluição $10^{-1} \mathrm{e}$, em cada tubo da terceira série, adicionou-se $1 \mathrm{~mL}$ da diluição $10^{-2}$.

Todos os tubos foram incubados em estufa termostatizada a $35-37^{\circ} \mathrm{C}$, por 24-48h. Após 24 e 48 horas de incubação, sendo positivos os resultados, foi possível observar o esvaziamento dos tubos de Durham, devido à produção de gás pelas bactérias do grupo coliforme ao fermentarem a lactose.

Alíquotas dos tubos positivos do teste presuntivo foram transferidas para o teste confirmativo, verificando-se, assim, se realmente, tratavam-se de bactérias do grupo coliforme.

Utilizando-se a alça de níquel-cromo, foram inoculados tubos de Caldo Verde Brilhante Lactose Bile (CVBLB), em concentração simples, e tubos de Caldo EC, correspondentes aos tubos positivos da fase anterior.

Os tubos de CVBLB foram incubados em estufa termostatizada à temperatura de $35-37^{\circ} \mathrm{C}$ durante $24-48 \mathrm{~h}$, sendo verificada, após esse período a 
formação ou não de gás nos tubos de Durham. A formação de gás em CVBLB, confirma a presença de bactérias do grupo coliforme, podendo ser de origem fecal ou não, denominadas coliformes totais.

Os tubos de EC, uma vez inoculados, foram incubados em banho-maria termostatizado à temperatura de $45^{\circ} \mathrm{C}$ por 24 horas. A formação de gás em EC, confirma a presença de coliformes fecais após esse período de incubação.

A partir do número de tubos positivos em cada série de ambos os meios, consultando-se seus valores correspondentes na tabela da Associação Brasileira de Normas Técnicas MB 3463 (vide ANEXO E), obteve-se o NMP de coliformes totais (CVBLB) e fecais (Caldo EC), por g de beterraba ralada.

\section{c) Detecção de Salmonella}

Para detecção de Salmonella, utilizou-se o Kit '1-2 test', fabricado pela BioControl/USA. Trata-se de um método oficial aprovado pela AOAC (Association of Official Analytical Chemists Internacional) para utilização em todos os tipos de alimentos.

Foi feito um pré-enriquecimento de cada amostra analisada, inoculandose $25 \mathrm{~g}$ de beterraba ralada em um erlenmeyer contendo $225 \mathrm{~mL}$ de água peptonada tamponada esterilizada. Os frascos foram incubados em estufa termostatizada, a $35^{\circ} \mathrm{C}$ por 24 horas. O pré-enriquecimento é possível pela exigência de ausência de Salmonella em $25 \mathrm{~g}$ de qualquer alimento analisado para consumo humano. Deste modo se a bactéria estiver presente no alimento, não importando o número de bactérias presentes, o alimento é considerado impróprio para o consumo humano. Com o pré-enriquecimento, sua multiplicação é favorecida, facilitando a detecção na análise, uma vez que tal patógeno encontra-se normalmente em níveis baixos nos alimentos. Decorrido o período de incubação fez-se o preparo dos kits, compostos, cada um, de dois compartimentos. A amostra pré-enriquecida foi inoculada na câmara de inoculação $(0,1 \mathrm{~mL})$ onde primariamente foi adicionada uma gota de solução de iodo-iodeto e depois removido o tampão desta câmara com auxílio de uma 
pinça estéril. A câmara de motilidade contém um meio de motilidade não seletivo, a base de peptona. Esta câmara é fechada por uma pequena ponteira (que foi retirada) para formar um vão no gel, e adicionou-se uma gota da solução de anticorpos polivalentes anti-Salmonella. Incubou-se os kits a 35ㄷ por 24 horas. Após a incubação foi feita a leitura dos resultados.

A possível presença de Salmonella é caracterizada pela formação de uma imunobanda na metade superior do gel na câmara de motilidade. Trata-se de uma banda branca que apresenta forma de $U$ formada pela aglutinação das células da bactéria com a solução de anticorpos.

\section{Análise dos resultados}

O delineamento experimental empregado foi inteiramente casualizado com 5 repetições. Cada repetição foi composta por uma bandeja contendo aproximadamente $180 \mathrm{~g}$ de beterraba. Os resultados das análises físicoquímicas foram submetidos à análise do desvio padrão. As diferenças entre dois tratamentos maior que a soma de dois desvios padrões foram consideradas significativas ( $P$ 0,05) (Moretti et al., 2002a). Para avaliação dos aspectos microbiológicos os resultados foram expressos em UFC/g de produto para bactérias psicrotróficas, NMP/g para coliformes totais e fecais e presença ou ausência de Salmonella em $25 \mathrm{~g}$ de produto.

\subsection{Resultados e Discussão}

\section{Taxa respiratória}

O processamento mínimo causou alteração significativa no metabolismo respiratório de beterrabas. As raízes intactas apresentaram a menor taxa respiratória durante o período avaliado (Figura 1), atingindo valores próximos de $5 \mathrm{~mL} \mathrm{CO} \mathrm{Kg}^{-1} \mathrm{~h}^{-1}$. Por outro lado, as raízes raladas apresentaram elevação significativa na atividade respiratória logo após o processamento mínimo, sendo seis vezes maior do que as raízes intactas, e atingindo valores próximos a 
$30 \mathrm{~mL} \mathrm{CO} \mathrm{kg}^{-1} \mathrm{~h}^{-1}$. Observou-se que as beterrabas descascadas também tiveram uma elevação na atividade respiratória, sendo aproximadamente quatro vezes maior do que as beterrabas intactas, até a terceira hora após o descascamento (Figura 1). Após 4 horas de armazenamento, não foi verificada diferença significativa na atividade respiratória entre raízes descascadas e raladas.

A intensidade da respiração é um dos fatores determinantes na longevidade dos produtos hortícolas após a colheita, considerando que a respiração é um processo oxidativo das substâncias de reserva, levando o órgão àsenescência (Wills et al., 1981).

A atividade respiratória é incrementada em tecidos injuriados, como é o caso do processamento mínimo. O descascamento e o corte efetuado nos produtos minimamente processados elevam a taxa respiratória dos mesmos devido às reações fisiológicas e bioquímicas se tornarem mais ativas, em resposta ao estresse (Watada et al., 1990). 


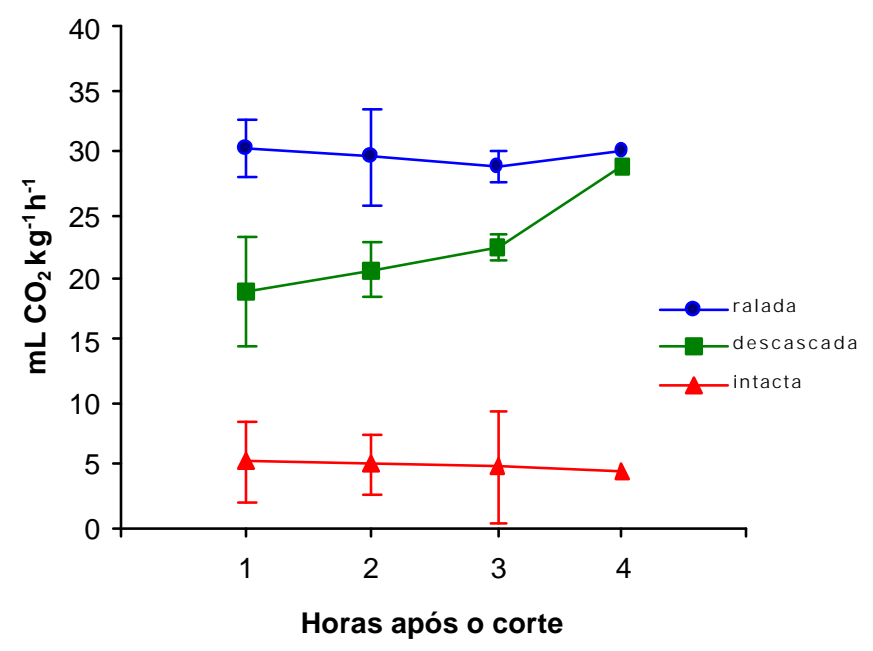

Figura 1 - Taxa respiratória de beterrabas intactas, descascadas e raladas logo após o corte a $5 \pm 1^{\circ} \mathrm{C}$ e $85 \pm 5 \%$ UR. Barras verticais representam desvio padrão da média.

As raízes raladas apresentaram a maior taxa respiratória no $2^{-}$dia de armazenamento (Figura 2). Neste dia observou-se um pico de $77,59 \mathrm{~mL}$ $\mathrm{CO}_{2} \mathrm{~kg}^{-1} \mathrm{~h}^{-1}$. A partir do $4^{\circ}$ dia verificou-se uma estabilização em valores próximos a $30 \mathrm{~mL} \mathrm{CO} \mathrm{kg}^{-1} \mathrm{~h}^{-1}$. Resultados similares foram obtidos por Osornio \& Chaves (1998), em beterrabas raladas e armazenadas a $0^{\circ} \mathrm{C}$.

O pico respiratório observado nas beterrabas minimamente processadas advém do estresse provocado pelo corte (Figura 2). Este estresse provoca uma perda da compartimentação celular e, com isto, os substratos do metabolismo respiratório entram em maior contato com os complexos enzimáticos resultando num aumento da taxa respiratória. A redução subseqüente na taxa respiratória das beterrabas minimamente processadas do controle (a partir do $4^{\circ}$ dia) ainda não está bem explicada. É possível que haja uma auto-regulação da atividade respiratória do tecido devida a grande produção de ATP (Purvis, 1997), ou que esta redução da taxa respiratória ocorra pelo fato dos substratos respiratórios 
pararem de reagir com as enzimas presentes nas células da superfície de corte. Portanto, a taxa respiratória observada a partir do $4^{\circ}$ dia pode ser resultante das células localizadas abaixo da superfície injuriada pelo corte.

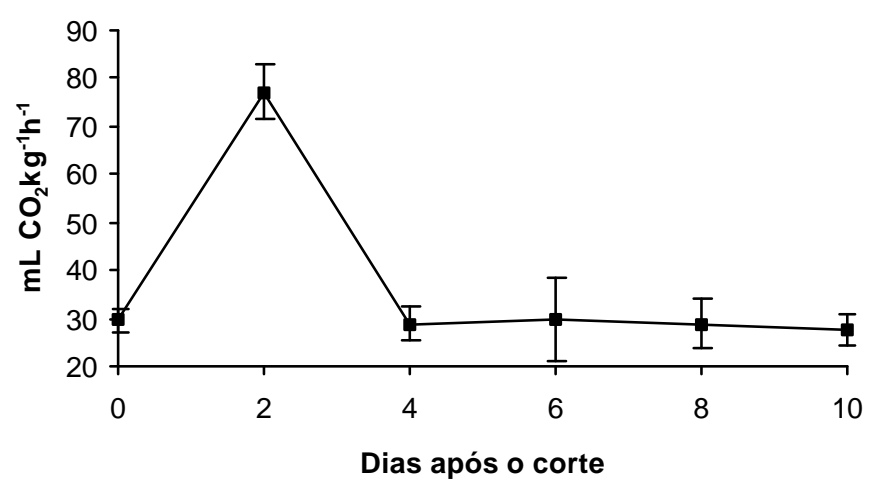

Figura 2 - Taxa respiratória de beterrabas raladas durante o armazenamento a $5 \pm 1^{\circ} \mathrm{C}$ e $85 \pm 5 \%$ UR. Barras verticais representam o desvio padrão da média.

Produções elevadas de $\mathrm{CO}_{2}$ imediatamente após o corte e decréscimo na evolução do $\mathrm{CO}_{2}$ durante o período de armazenamento têm sido relatadas por vários autores. Bastrash et al. (1993) observaram em experimento com floretes de brócolos que a atividade respiratória foi $40 \%$ superior após 7 horas do processamento mínimo, sendo que esta atividade decresceu durante os 6 primeiros dias de armazenamento a $4 \stackrel{\circ}{\circ}$. Smyth et al. (1998) observaram que a taxa de respiração de alfaces minimamente processadas decresceu de, aproximadamente, $470 \mathrm{pmol} \mathrm{g}^{-1} \mathrm{~s}^{-1}$ (1 hora após o corte) para 150pmol g-1 $\mathrm{s}^{-1}$ (24 horas após o corte), permanecendo praticamente constante até 0 final do experimento. 


\section{Produção de etileno}

Não foi detectado etileno durante as 4 primeiras horas em beterrabas intactas e descascadas, sendo a produção de etileno gerada nestas condições considerada muito baixa $\left(<0,1 \mu \mathrm{L} \mathrm{C}_{2} \mathrm{H}_{4} \mathrm{~kg}^{-1} \mathrm{~h}^{-1}\right)$. Já para as beterrabas raladas, a produção de etileno nas primeiras horas após o corte atingiu valores na ordem de $0,90 \mu \mathrm{L} \mathrm{C}_{2} \mathrm{H}_{4} \mathrm{~kg}^{-1} \mathrm{~h}^{-1}$ (Figura 3), havendo pouca variação ao longo das quatro horas de avaliação e durante o período de conservação (Figura 4).

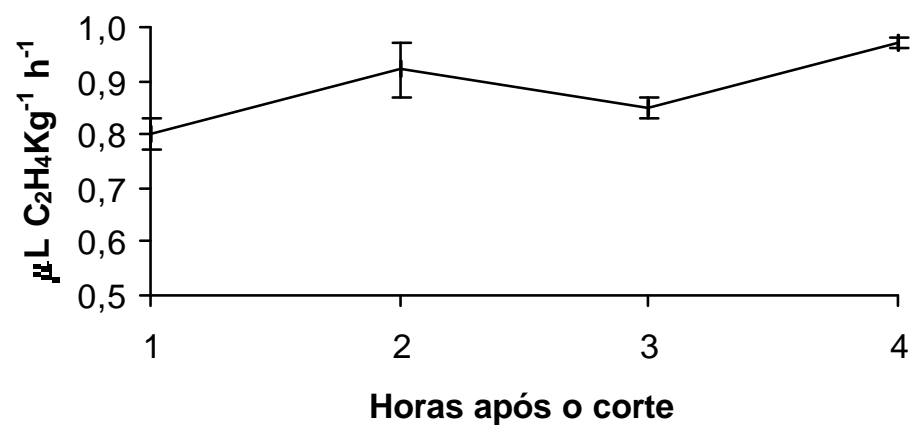

Figura 3 - Produção de etileno de beterrabas raladas logo após o corte a $5 \pm 1^{\circ} \mathrm{C}$ e $85 \pm 5 \%$ UR. Barras verticais representam o desvio padrão da média. 


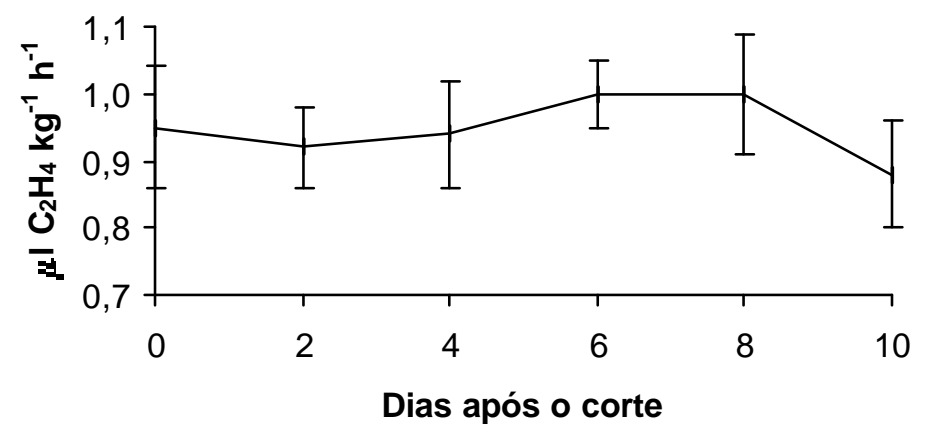

Figura 4 - Produção de etileno de beterrabas raladas armazenadas a $5 \pm 1{ }^{\circ} \mathrm{C} \mathrm{e}$ $85 \pm 5 \%$ UR. Barras verticais representam o desvio padrão da média.

De acordo com Sakr et al. (1997), o aumento da produção de etileno pode ser uma resposta hormonal e bioquímica devido ao estresse causado pelo corte. Isto ocorre pois o primeiro alvo desse estresse é a membrana plasmática, a qual responde com mudanças em suas características físicas, de forma a contornar tais perturbações e tentar reparar os danos causados durante o processamento.

\section{Análises microbiológicas}

A contagem inicial das bactérias psicrotróficas foi de aproximadamente $2,62 \times 10^{2} \mathrm{UFC} / \mathrm{g}$ (Tabela 1 ), ao passo que no $10^{\circ}$ dia de armazenamento as contagens obtidas aumentaram para valores próximos de $2,04 \times 10^{4} \mathrm{UFC} / \mathrm{g}$. Piagentini et al. (1997) relataram aumento na população de microrganismos psicrotróficos em repolho minimamente processado, de $10^{2}$ para $10^{5} \mathrm{UFC} / \mathrm{g}$, após quatro dias de armazenamento do produto a $4^{\circ} \mathrm{C}$. García-Gimeno \& Zurera-Cosano (1997) observaram aumento de $10^{5}$ para $10^{7} \mathrm{UFC} / \mathrm{g}$ na contagem de microrganismos psicrotróficos em amostras de saladas de hortaliças minimamente processadas armazenadas a $4^{\circ} \mathrm{C}$. 
Tabela 1. Contagem total de bactérias psicrotróficas, em beterrabas minimamente processadas armazenadas a $5 \pm 1^{\circ} \mathrm{C}$ e $85 \pm 5 \%$ UR, utilizando-se a metodologia convencional (PCA).

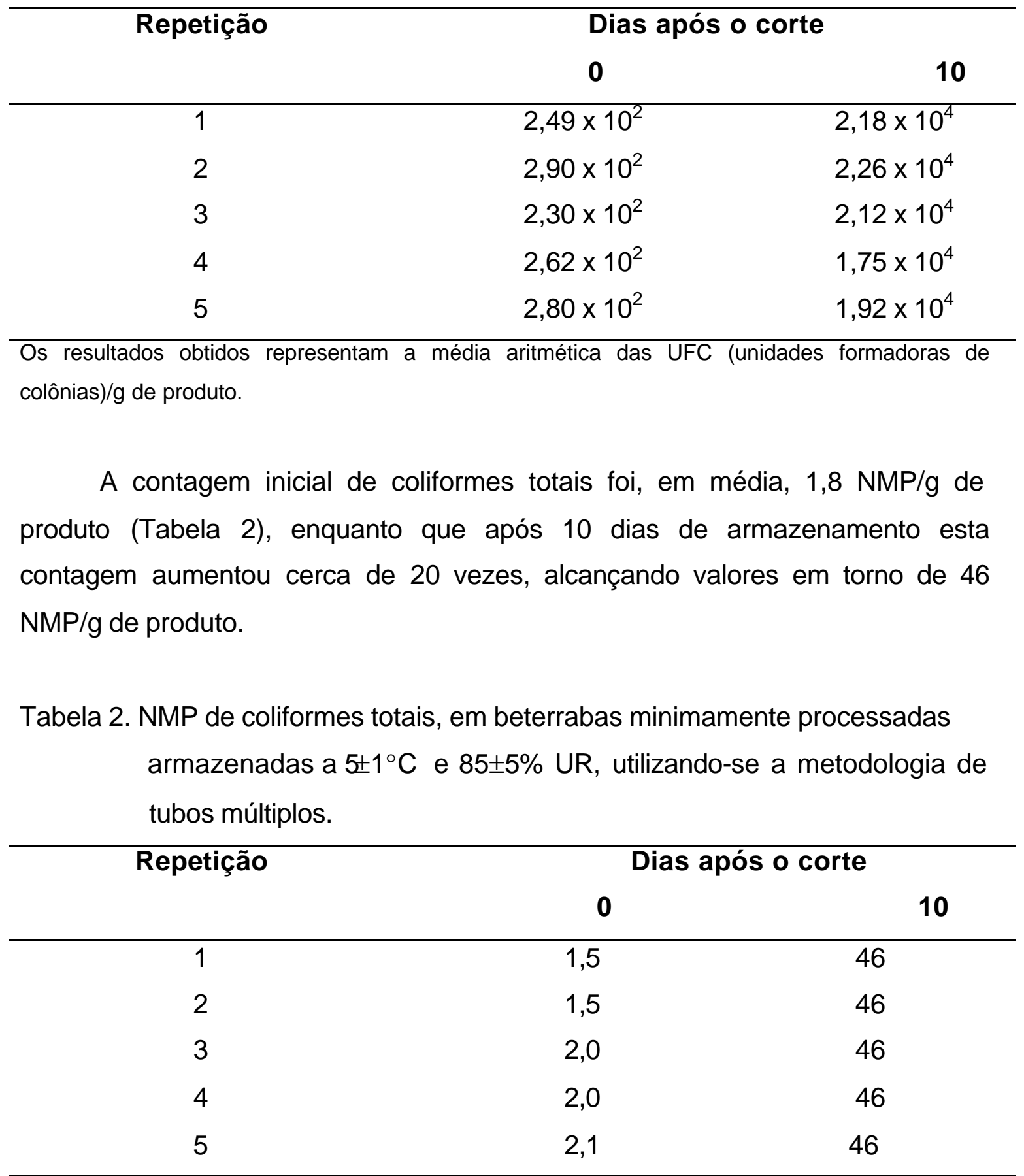

Os resultados obtidos representam o NMP de coliformes totais/g de produto. 
Embora não existam, na legislação brasileira vigente padrões, para bactérias psicrotróficas totais e coliformes totais, no que diz respeito à quantidade de microrganismos presentes em um alimento, pode-se afirmar que quantidades elevadas (> $10^{5} \mathrm{UFC} / \mathrm{g}$ ) são completamente indesejáveis, pelo menos pelas seguintes razões: risco do alimento estar estragado, perda real ou potencial das qualidades organolépticas, comprometimento da aparência do alimento; quanto maior o número de microrganismos em um alimento, maiores são as possibilidades da presença de patogênicos e/ou deterioradores (Caruso \& Camargo, 1984). No presente trabalho, as amostras de beterrabas com 10 dias de armazenamento, apresentavam-se abaixo deste limite.

Em nenhuma das amostras de beterrabas analisadas houve detecção de coliformes fecais (Tabela 3). Na metodologia de Tubos Múltiplos, quando aparece o resultado $<0,3 \mathrm{NMP} / \mathrm{g}$ significa que nenhum dos tubos inoculados se mostrou positivo.

Tabela 3. NMP de coliformes fecais, em beterrabas minimamente processadas armazenadas a $5 \pm 1^{\circ} \mathrm{C}$ e $85 \pm 5 \%$ UR, utilizando-se a metodologia de tubos múltiplos.

\begin{tabular}{ccc}
\hline Repetição & Dias após o corte & \\
& $\mathbf{0}$ & $\mathbf{1 0}$ \\
\hline 1 & $<0,3$ & $<0,3$ \\
2 & $<0,3$ & $<0,3$ \\
3 & $<0,3$ & $<0,3$ \\
4 & $<0,3$ & $<0,3$ \\
5 & $<0,3$ & $<0,3$ \\
\hline
\end{tabular}

Os resultados obtidos representam o NMP de coliformes fecais/g de produto.

Para frutas e hortaliças minimamente processadas, ainda não existe uma legislação com os limites de contagens toleradas. Entretanto, estes resultados estão dentro do limite estabelecido pela resolução RDC no 12 de 02 de janeiro 
de 2001 da Agência Nacional de Vigilância Sanitária (ANVISA) do Ministério da Saúde, de no máximo, $10^{2} \mathrm{NMP}$ de coliformes fecais/g de hortaliça fresca.

Não foi detectada a presença de Salmonella em nenhuma das repetições analisadas durante o armazenamento (Tabela 4). Tais resultados, colocam as amostras analisadas em acordo com a Resolução RDC № 12 de 02 de janeiro de 2001, da Agência Nacional de Vigilância Sanitária (ANVISA) do Ministério da Saúde, que estabelece para hortaliças in natura a ausência de Salmonella (em $25 \mathrm{~g}$ de produto) visando a preservação da saúde pública.

Tabela 4. Detecção de Salmonella em $25 \mathrm{~g}$ de beterrabas minimamente processadas e armazenadas a $5 \pm 1^{\circ} \mathrm{C}$ e $85 \pm 5 \%$ UR, utilizando-se 0 kit "1-2 test" da BioControl/USA.

\begin{tabular}{ccc}
\hline Repetição & \multicolumn{2}{c}{ Dias após o corte } \\
\hline 1 & Ausência & $\mathbf{1 0}$ \\
2 & Ausência & Ausência \\
3 & Ausência & Ausência \\
4 & Ausência & Ausência \\
5 & Ausência & Ausência \\
\hline
\end{tabular}

O processamento mínimo causa efeitos significativos nos processos fisiológicos de beterrabas. Raízes intactas apresentam uma taxa respiratória relativamente baixa quando comparada com beterrabas raladas. $O$ mesmo pode ser observado para produção de etileno, que no caso de beterrabas intactas não foi possível de ser detectado. Assim, torna-se óbvio que as operações de processamento mínimo, principalmente descascamento e corte, ao elevar a taxa respiratória e a taxa de síntese de etileno da beterraba, contribuam para a redução na vida útil desta hortaliça minimamente processada. Como não foram observadas presenças de bactérias coliformes 
fecais e de Salmonella nas amostras analisadas, ficou evidenciada a eficácia dos cuidados higiênico-sanitários realizados durante as etapas de processamento do produto, enquadrando-o nos padrões microbiológicos vigentes no país.

\subsection{Conclusões}

$\checkmark$ A taxa respiratória e a produção de etileno é aumentada com o processamento mínimo de beterrabas.

$\checkmark$ Os cuidados tomados quanto as condições higiênicas levaram à obtenção de um produto com padrão microbiológico de acordo com a legislação de alimentos, até o $10^{\circ}$ dia de armazenamento. 


\section{ATIVIDADE RESPIRATÓRIA E METABOLISMO DOS PIGMENTOS DE BETERRABAS MINIMAMENTE PROCESSADAS TRATADAS COM ÁCIDO CÍTRICO}

\section{RESUMO}

Um dos principais problemas tecnológicos em raízes de beterrabas minimamente processadas é a degradação dos pigmentos com subseqüente perda da coloração. Os efeitos do ácido cítrico na atividade respiratória e no teor de betalaínas em raízes de beterrabas minimamente processadas foram avaliados. Beterrabas, cv. Early Wonder, foram selecionadas quanto à firmeza, cor e tamanho e descascadas em câmara fria $\left(10 \pm 1^{\circ} \mathrm{C}\right)$. As raízes foram cortadas (2mm de espessura), sanitizadas (200ppm de cloro ativo), enxaguadas (3ppm de cloro ativo) e centrifugadas (2000rpm). As beterrabas foram tratadas com ácido cítrico nas seguintes concentrações: 0 (controle), 500, 1000,1500 e $2000 \mathrm{mg} \mathrm{L}^{-1}$. O produto foi novamente centrifugado, colocado em

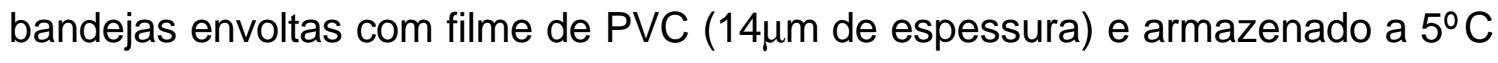
e $85-90 \%$ de umidade relativa durante 10 dias. A cada 2 dias, foram avaliados a atividade respiratória e os teores de betacianina e betaxantina nos tratamentos. A aplicação de ácido cítrico nas diferentes concentrações reduziu a taxa respiratória nos tecidos minimamente processados. No segundo dia de armazenamento, o tratamento controle apresentou a maior atividade respiratória alcançando valores ao redor de $77 \mathrm{~mL} \mathrm{CO}_{2} \mathrm{~kg}^{-1} \mathrm{~h}^{-1}$. A aplicação de ácido cítrico igual ou maior que $500 \mathrm{mg} \mathrm{L}^{-1}$ contribui para decréscimo da atividade respiratória e o pico na evolução de $\mathrm{CO}_{2}$ não foi observado. Foi 
verificado diferença significativa entre os tratamentos durante todo 0 armazenamento para os teores de betacianina, tendo sido observado valores

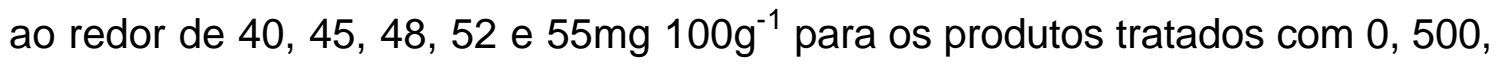
1000,1500 e $2000 \mathrm{mg} \mathrm{L}^{-1}$, respectivamente. Os níveis de betaxantina para beterrabas minimamente processadas foram ao redor de 25, 29, 33, 35 e $39 \mathrm{mg}$ $100 \mathrm{~g}^{-1}$ para os tratamentos de $0,500,1000,1500$ e $2000 \mathrm{mg} \mathrm{L}^{-1}$, respectivamente. A aplicação de ácido cítrico é sugerida durante o processamento mínimo como forma de reduzir a taxa respiratória e a degradação de pigmentos, contribuindo assim para o aumento da vida de prateleira de produtos minimamente processados.

Palavras-chave: Beta vulgaris L., betalaína, betacianina, betaxantina, processamento mínimo.

\section{RESPIRATORY ACTIVITY AND PIGMENT METABOLISM IN FRESH-CUT BEET ROOTS TREATED WITH CITRIC ACID}

\section{Summary}

Pigment degradation and subsequent loss of the characteristic pinkreddish color is one of the major technological problems in fresh-cut beet roots. The effects of citric acid in the respiratory activity and in the content of betalain were evaluated in fresh-cut beet roots. Beet roots cv. Early Wonder, obtained from a local grower, were graded for firmness, color and size, and were peeled inside a cold room $\left(10 \pm 1^{\circ} \mathrm{C}\right)$. Roots were then shredded (2mm thick), sanitized for 6 minutes (200ppm free chlorine), and rinsed for 1 minute (3ppm free chlorine), and centrifuged (2000rpm) for 1 minute. Fresh-cut beet roots were then treated for 5 minutes with citric acid in the following concentrations: 0 (control), 500, 1000, 1500 e $2000 \mathrm{mg} \mathrm{L}^{-1}$. The material was centrifuged again,

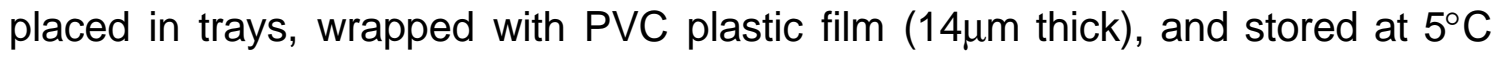
and $85-90 \% \mathrm{RH}$ for 10 days. Every two days, treatments were analyzed for 
respiratory activity and betacyanin and betaxanthin contents. The application of citric acid caused the reduction of respiratory rate in the fresh-cut tissue. In the second day of storage, control showed the highest respiratory activity among treatments, reaching around $77 \mathrm{~mL} \mathrm{CO}_{2} \mathrm{~kg}^{-1} \mathrm{~h}^{-1}$. Citric acid solution dips in a concentration higher than $500 \mathrm{mg} \mathrm{L}^{-1}$ contributed to a decrease in respiratory activity and no peak in $\mathrm{CO}_{2}$ evolution was observed. There were significant differences among treatments during the storage period for the contents of

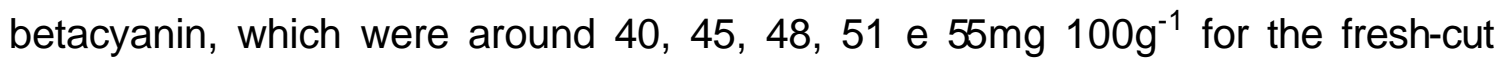
material treated with $0,500,1000,1500$ e $2000 \mathrm{mg} \mathrm{L}^{-1}$ of citric acid, respectively. On the other hand, levels of betaxanthin in fresh-cut beet roots were around 25, $29,33,35$ e $39 \mathrm{mg}^{2} 100 \mathrm{~g}^{-1}$ for the material treated with $0,500,1000,1500 \mathrm{e}$ $2000 \mathrm{mg} \mathrm{L}^{-1}$ of citric acid, respectively. It is suggested that the application of citric acid after minimal processing have the ability to reduce respiratory rate and the degradation of pigments, which contributes to extend the shelf life of he freshcut product.

Key-words: Beta vulgaris L., betalain, betacyanin, betaxanthin, minimal processing.

\subsection{Introdução}

Durante os últimos anos os produtos minimamente processados vem crescendo rapidamente tanto ao nível de varejo quanto de restaurantes. Visando conveniência por parte dos consumidores, estes produtos são preparados e manuseados objetivando oferecer um produto fresco e saudável (Moretti \& Sargent, 2002). A obtenção de produtos minimamente processados envolve muitas etapas como limpeza, lavagem, corte, descascamento, fatiamento, e outras operações relacionadas (Cantwell, 2000).

O mercado de produtos minimamente processados é uma atividade que vem mostrando aumento exponencial em muitos países, especialmente em grandes áreas metropolitanas, como em São Paulo, onde os supermercados 
vendem ao redor de 4 milhões de dólares por mês destes produtos, sendo que as frutas correspondem a (54\%) e as hortaliças a (46\%) (Rojo \& Saabor, 2002).

Em geral, produtos minimamente processados têm uma vida de prateleira mais curta quando comparado com produtos intactos, devido principalmente ao estresse mecânico na superfície dos tecidos. Na superfície do corte, as células e membranas celulares são rompidas e isto acarreta em várias alterações no metabolismo do tecido. Dentre as diferentes alterações, muitos autores observaram aumento da taxa respiratória e da síntese de etileno (Brecht, 1995; Moretti et al., 1998; 2000; 2002a), perda de água (Chuma et al., 1984), alterações no sabor e aroma (Moretti \& Sargent, 2000), nos compostos voláteis (Moretti et al., 2002b) e aumento da atividade de enzimas relacionadas com escurecimento enzimático, como a fenilalanina amônia-liase (Ke \& Saltveit, 1989) e polifenoloxidase (Bower \& Van Lelyveld, 1985; Nicoli et al., 1994).

A conservação de um produto está relacionada com a taxa respiratória, sendo que esta é diretamente proporcional à perecibilidade. Os produtos minimamente processados são mais perecíveis que tecidos intactos e, portanto, tratamentos que reduzam a respiração são importantes para aumento na vida de prateleira. Kato-Noguchi \& Watada (1997) observaram que a taxa respiratória de cenouras minimamente processadas foi substancialmente reduzida com a aplicação de ácido cítrico. O ácido cítrico está envolvido na inibição da enzima fosfofrutoquinase, que catalisa a fosforilação da frutose 6 fosfato em frutose 1,6- bisfosfato na via glicolítica do metabolismo respiratório (Turner \& Turner, 1980).

Dentre as muitas frutas e hortaliças que estão sendo minimamente processadas no Brasil, a beterraba está aumentando sua importância. Esta raiz tuberosa possui uma coloração vermelho-arroxeada devido a presença dos pigmentos de betalaínas. As betalaínas são compostos que foram denominados incorretamente por antocianinas que continham nitrogênio. São pigmentos hidrossolúveis e estão divididas em duas classes: betacianina (responsável pela 
coloração avermelhada) e betaxantina (responsável pela coloração amarelada), caracterizando a coloração típica das raízes (Fenena, 1995).

Um dos principais problemas tecnológicos observado por processadores que trabalham com beterraba minimamente processada é a descoloração significativa e desidratação do material minimamente processado. As operações de lavagem, sanitização e enxague realizadas após o corte favorecem a perda de betacianina e betaxantina; devido à estes pigmentos serem solúveis em água (Nilson, 1970).

Considerando os fatores acima citados, a importância econômica deste vegetal e a falta de informação na literatura relativa ao estudo desta hortaliça minimamente processada focalizando degradação de pigmentos, o presente trabalho teve como objetivo estudar os efeitos do ácido cítrico na atividade respiratória e no teor de betalaínas em raízes de beterraba minimamente processada.

\subsection{Material e Métodos}

O experimento foi conduzido no Laboratório de Pós-Colheita do Departamento de Produção Vegetal, da ESALQ/ USP, em Piracicaba-SP. As raízes de beterrabas, cv. Early Wonder, foram adquiridas de um produtor da região de Piracicaba.

Efetuou-se uma seleção cuidadosa quanto ao tamanho, firmeza, cor e formato, tendo sido descartadas raízes murchas e com defeitos ou injúrias. Todas as etapas de preparo ocorreram dentro da câmara a $10 \pm 1^{\circ} \mathrm{C}$, sendo as beterrabas pré-lavadas, descascadas (remoção da película externa) por uma descascadora industrial (Shymsen) e imersas em água resfriada $\left(5 \pm 0,5^{\circ} \mathrm{C}\right)$ por 2 minutos para manter da atividade metabólica do produto baixa (vide ANEXO A).

O processamento mínimo foi feito utilizando-se uma processadora industrial (Robot Coupe), com disco de $2 \mathrm{~mm}$ de espessura de corte. Após o corte em retalhos, o material foi sanitizado por 6 minutos em água clorada (200ppm de cloro ativo), com o objetivo de reduzir riscos de contaminação, e 
enxaguado por 1 minuto (em água com 3ppm de cloro ativo) para retirar o excesso de cloro do produto. O sanitizante utilizado, em ambas as etapas, foi o SUMAVEG, este produto tem como principio ativo o Dicloro-S-Triazinatriona Sódica Diidratada e é fabricado pela Diversey Lever-Indústrias Gessy Lever Ltda.

Para a retirada do excesso de água, as beterrabas minimamente processadas foram centrifugadas (2000rpm) utilizando-se centrífuga doméstica (ARNO) por 1 minuto.

Após o preparo, o produto minimamente processado foi separado em 5 lotes, seguindo-se da aplicação de ácido cítrico na forma de imersão (5 minutos) em solução com diferentes concentrações: $0 \mathrm{mg} \mathrm{L}^{-1}$ (imersão em água), $500 \mathrm{mg} \mathrm{L}^{-1}, 1000 \mathrm{mg} \mathrm{L}^{-1}, 1500 \mathrm{mg} \mathrm{L}^{-1}$ e $2000 \mathrm{mg} \mathrm{L}^{-1}$. Após esta aplicação realizou-se uma segunda centrifugação, idêntica a anterior.

Todos os tratamentos foram acondicionados em bandejas de poliestireno expandido, com dimensões $14 \times 20 \mathrm{~cm}$ de largura e comprimento, respectivamente, envolvidas por filme de policloreto de vinila (PVC), com 14 micras de espessura e armazenados a $5 \pm 1^{\circ} \mathrm{C}$ e $85 \pm 5 \%$ UR.

O período de armazenamento foi de 10 dias, sendo que as avaliações foram realizadas a cada 2 dias.

Para a análise da taxa respiratória, $180 \mathrm{~g}$ de beterrabas minimamente processadas foram colocadas em frascos de vidro com capacidade $600 \mathrm{~mL}$, sendo fechados hermeticamente durante 1 hora a $5^{\circ} \mathrm{C}$. Na tampa dos frascos foi colocado um septo de silicone através do qual foi retirada uma alíquota da atmosfera interna dos frascos $(2 \mathrm{~mL})$ e medido o conteúdo de $\mathrm{CO}_{2}$ em um analisador de gases PBI Dansensor 9900. Os resultados expressos em \% $\mathrm{CO}_{2}$ foram utilizados para cálculo da taxa respiratória levando-se em consideração o volume do frasco, a massa da beterraba e o tempo em que o frasco permaneceu fechado. Os resultados foram expressos em $\mathrm{mL} \mathrm{CO}_{2} \mathrm{~kg}^{-1} \mathrm{~h}^{-1}$.

A metodologia utilizada para a determinação de betacianina $e$ betaxantina foi adaptada de Nilson (1970), onde $2 \mathrm{~g}$ de amostras previamente 
congeladas foram maceradas em $5 \mathrm{~mL}$ de água destilada. A solução foi colocada em tubetes e centrifugadas utilizando-se centrifuga refrigerada (Sorvall) $4^{\circ} \mathrm{C}$, rotação de 15000 rpm, durante 40 minutos. Num tubo de ensaio foram homogenizados $1 \mathrm{~mL}$ do sobrenadante e $24 \mathrm{~mL}$ de água destilada. Foram feitas leituras das amostras a 476nm, 538nm e 600nm. Os cálculos foram realizados através das seguintes fórmulas: $x=1,095(a-c), y=b-z-x / 3,1$ e $z=a-x$, sendo: $a=$ leitura da amostra (538nm); b= leitura da amostra $(476 \mathrm{~nm})$; $c=$ leitura da amostra (600nm); $x=$ absorção de betacianina; $y=$ absorção de betaxantina; $z=$ absorção de impurezas.

$O$ delineamento experimental empregado foi inteiramente casualizado em esquema fatorial 5x6 (5 concentrações de ácido cítrico e 6 períodos de armazenamento). Foram utilizadas 5 repetições. Cada repetição foi composta por uma bandeja contendo aproximadamente $180 \mathrm{~g}$ de beterraba. Os resultados das análises físico-químicas foram submetidos à análise do desvio padrão. As diferenças entre dois tratamentos maior que a soma de dois desvios padrões foram consideradas significativas ( $P$ 0,05) (Moretti et al., 2002a).

\subsection{Resultados e Discussão}

A aplicação de ácido cítrico em diferentes concentrações causou redução da atividade respiratória de beterrabas minimamente processadas. Raízes minimamente processadas do controle apresentaram a maior taxa de evolução de $\mathrm{CO}_{2}$, a partir do $2^{\circ}$ dia de armazenamento (Figura 1a). Neste dia observouse um pico de $77,59 \mathrm{~mL} \mathrm{CO}_{2} \mathrm{~kg}^{-1} \mathrm{~h}^{-1}$. A partir do $4^{\circ}$ dia verificou-se uma estabilização em valores próximos a $30 \mathrm{~mL} \mathrm{CO}_{2} \mathrm{~kg}^{-1} \mathrm{~h}^{-1}$ para este tratamento.

A aplicação igual ou superior a $500 \mathrm{mg} \mathrm{L}^{-1}$ de ácido cítrico fez com que a taxa respiratória fosse diminuída, e, ao contrário do observado para o controle, não houve pico na respiração (Figura 1a).

Os valores em que a atividade respiratória se estabilizou a partir do $2^{\circ}$ dia de armazenamento foram próximos a 25, 18, 10 e 3,5mL $\mathrm{CO}_{2} \mathrm{~kg}^{-1} \mathrm{~h}^{-1}$ para 
500, 1000, 1500 e 2000 $\mathrm{mg} \mathrm{L}^{-1}$ de ácido cítrico, respectivamente. Estes resultados são semelhantes aos observados por Kato-Noguchi \& Watada (1997) que verificaram que a atividade respiratória de cenouras minimamente processadas foi reduzida de acordo com o incremento na concentração de ácido cítrico.

O pico na taxa respiratória de beterrabas minimamente processadas e não tratadas com o ácido cítrico se deve, provavelmente, ao estresse provocado pelo corte do produto, o que causa uma perda da compartimentação celular e faz com que substratos do metabolismo respiratório entrem em maior contato com os complexos enzimáticos, resultando num aumento da atividade respiratória. Por outro lado, o ácido cítrico também pode ter servido como sinalizador para um abaixamento da atividade respiratória ou ainda, conforme preconizado por Kato-Noguchi \& Watada (1997), pode ter havido uma redução na atividade da fosfofrutoquinase, com subsequente redução na produção de ácido pirúvico na glicólise.

A redução subseqüente na taxa respiratória das beterrabas minimamente processadas do controle (a partir do $4^{\circ}$ dia) se deve provavelmente a uma auto-regulação da atividade respiratória do tecido devido a grande produção de ATP (Purvis,1997). Esta auto-regulação em beterrabas minimamente processadas tratadas com ácido cítrico deve ter ocorrido mais rapidamente após o processamento mínimo.

Quanto ao teor de betacianina, foi observado que houve diferença significativa entre os tratamentos no decorrer dos dias de armazenamento (Figura 1b). Os teores de betacianina ficaram em valores próximos de 40, 45, 48,51 e $55 \mathrm{mg} 100 \mathrm{~g}^{-1}$ para os tratamentos $0,500,1000,1500$ e $2000 \mathrm{mg} \mathrm{L}^{-1}$ de ácido cítrico, respectivamente.

O teor de betaxantina diferiu significativamente entre os tratamentos durante o período de armazenamento. Os teores de betaxantina obtidos em beterrabas minimamente processadas submetidas a diferentes concentrações de ácido 
cítrico atingiu valores próximos de 25, 29, 33, 35 e 39mg $100 \mathrm{~g}^{-1}$ para 0, 500, 1000, 1500 e 2000 $\mathrm{mg} \mathrm{L}^{-1}$ de ácido cítrico, respectivamente (Figura 1c).

De acordo com Nilson (1973), o teor de betacianina e betaxantina varia em função da cultivar de beterraba. Segundo o autor, os teores de betacianina e betaxantina para beterrabas intactas, podem variar de $45-210$ e $20-140 \mathrm{mg}$ $100^{-1}$, respectivamente.

Os pigmentos de betalaínas são mais solúveis em água do que em álcool (Nilson, 1970). No caso de beterrabas minimamente processadas os processos de sanitização e enxague favorecem uma maior perda destes pigmentos devido ao maior contato da superfície das raízes com a água. A imersão em ácido cítrico ou em outro tipo de antioxidante parece reduzir o extravazamento do pigmento. O aumento da concentração de ácido cítrico diminui a degradação de pigmentos durante todo armazenamento (Figura 1b e c). 


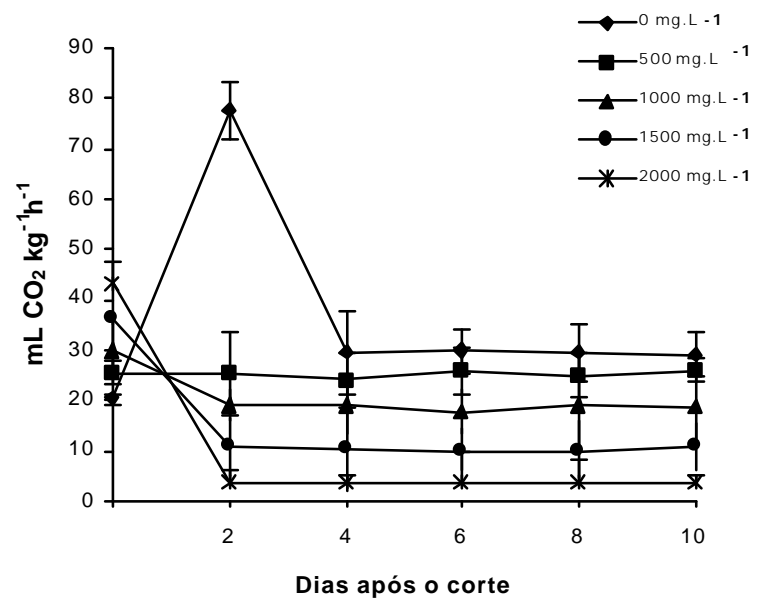

(a)

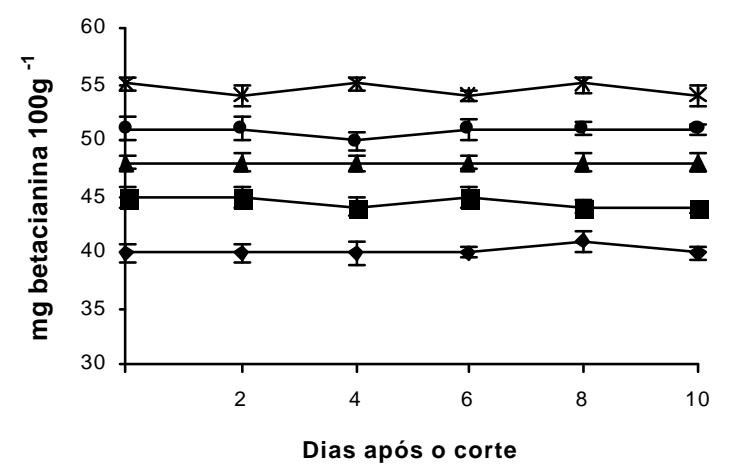

(b)

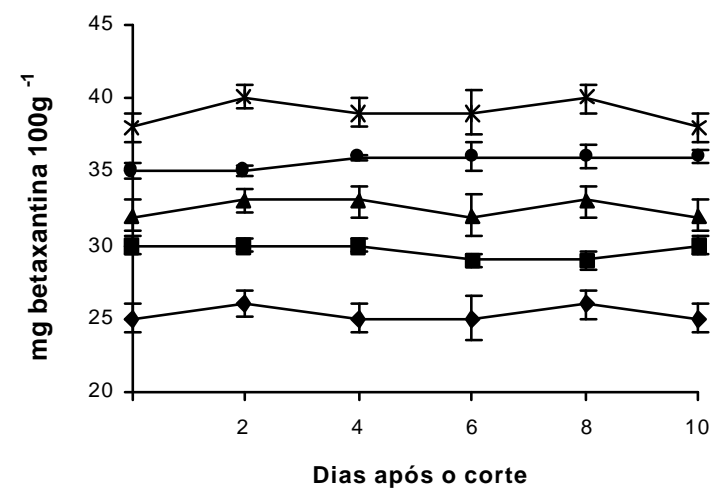

(c)

Figura 1 - Atividade respiratória (a), teor de betacianina (b) e teor de betaxantina (c) de beterrabas minimamente processadas tratadas com ácido cítrico e armazenadas a $5 \pm 1^{\circ} \mathrm{C}$ e $85 \pm 5 \%$ UR. As barras verticais indicam o desvio padrão da média. 
Observa-se também que quanto maior a concentração de ácido cítrico em que as beterrabas minimamente processadas foram imersas, menor foi a perda de pigmentos, o que pode ser observado pela coloração da água de imersão (Figura 2).

Salgado (1997) observou que a adição de antioxidante, como o ácido ascórbico, melhora a estabilidade do pigmento de betalaína em beterraba, sendo que a concentração de $400 \mathrm{mg} \mathrm{L}^{-1}$ foi a melhor para preservar a cor do produto. Assim, o ácido cítrico teve semelhante efeito ao ácido ascórbico em beterrabas. Ambos os ácidos usados em combinação não obtiveram efeito maior do que quando utilizados isoladamente (Attoe \& Elbe, 1985).

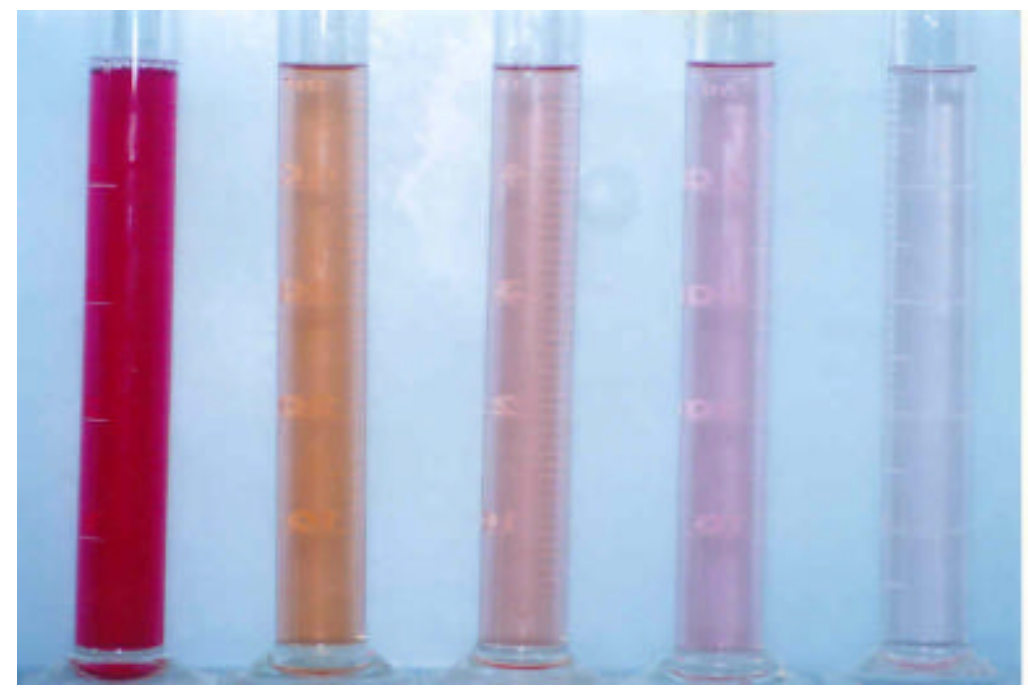

Figura 2 - Água de imersão de beterrabas minimamente processadas tratadas com ácido cítrico (da esquerda para direita: 0, 500, 1000, 1500 e $2000 \mathrm{mg} \mathrm{L}^{-1}$ de ácido cítrico).

\subsection{Conclusão}

- Pelos resultados observados infere-se que o ácido cítrico tem a capacidade de reduzir a taxa respiratória e evitar a perda de pigmentos de 
betalaínas em beterrabas minimamente processadas e pode, assim, contribuir para um aumento na conservação do produto. 


\section{TEMPO DE SANITIZAÇÃO PARA BETERRABAS MINIMAMENTE PROCESSADAS}

\section{Resumo}

Raízes de beterrabas, cv. Early Wonder, foram minimamente processadas e submetidas a diferentes tempos de sanitização: controle (sem sanitização), 3 minutos, 6 minutos, 9 minutos e 12 minutos. Após os tratamentos, o produto foi colocado em bandejas envoltas com filme de PVC e armazenado a $5 \pm 1^{\circ} \mathrm{C}$ e $85 \pm 5 \%$ UR durante 10 dias. Realizou-se análises físicoquímicas, sensoriais e microbiológicas durante o armazenamento refrigerado. Não foi detectada presença de coliformes fecais e Salmonella. A contagem de coliformes totais e bactérias psicrotróficas foi maior para beterrabas não sanitizadas. Houve um decréscimo nos teores dos pigmentos durante a conservação. De maneira geral, as características sensoriais foram pouco influenciadas pelos tratamentos, diferenido apenas para beterrabas controle. Os teores de betacianina e betaxantina foram maiores para beterrabas não sanitizadas, enquanto que os tratamentos por 6, 9 e 12 minutos de sanitização não diferiram entre si durante 0 armazenamento. $O$ teor de sólidos solúveis totais foi menor à medida que o tempo de sanitização aumentou. A sanitização por 3 minutos é a mais recomendada para manutenção da qualidade por reduzir perda de pigmentos e garantir a segurança alimentar do produto.

Palavras-chave: Beta vulgaris L., betacianina, betaxantina, processamento mínimo, microbiologia. 


\section{SANITIZATION TIME FOR FRESH-CUT BEET ROOT}

\section{Summary}

Early Wonder beet roots were minimally processed and submitted to different sanitization times: control (no sanitization), 3-, 6-, 9- and 12-minute sanitization. After treatment, the product was placed on trays, wrapped in PVC film and stored at $5 \pm 1^{\circ} \mathrm{C}$ and $85 \pm 5 \% \mathrm{RH}$ for 10 days. Sensory, physicochemical and microbiological analyses were conducted during refrigerated storage. Fecal coliforms and Salmonella were not detected. Total coliforms and psychotropic bacteria counts were higher for non-sanitized beet roots. There was a decrease in pigment amounts during storage. Sensory characteristics were generally little influenced by treatments, except for the control. Betacyanin and betaxanthin amounts were higher in non-sanitized beet roots, while 6-, 9- and 12-minute sanitization treatments did not differ from one another during storage. It was verified that the longer the sanitization time the less the total soluble solids amount. The 3-minute sanitization is the most recommended treatment for quality maintenance, as it reduces pigment loss and ensures food safety standards for consumption.

Key-words: Beta vulgaris L., betacyanin, betaxanthin, minimal processing, microbiology.

\subsection{Introdução}

A beterraba pertence a família Chenopodiaceae na qual sua parte comestível é a raiz tuberosa. Esta hortaliça tem uma típica coloração vermelhoescuro devido aos pigmentos de betalaínas. As betalaínas são um grupo de compostos semelhantes as antocianinas e flavonóides. Foram denominadas incorretamente, na bibliografia antiga, por antocianinas que continham 
nitrogênio. Encontram-se presentes somente em 10 famílias da ordem Centrospermae. São pigmentos hidrossolúveis e estão divididas em duas classes: betacianina (responsável pela coloração avermelhada) e betaxantina (responsável pela coloração amarelada), caracterizando a coloração típica das raízes de beterraba (Fenena, 1995).

A beterraba é uma hortaliça que tem apresentado grande expansão no mercado de pré-processados. Entretanto, tem sido observada elevada perda de qualidade em função da descoloração da superfície das raízes minimamente processadas e da elevada desidratação. Os processos de lavagem, sanitização e enxague, realizados após o corte do produto, têm favorecido a perda dos pigmentos de betalaínas.

Durante o processo de preparo dos produtos minimamente processados, as etapas de sanitização e enxague são essenciais, como forma de minimizar a deterioração e manter a qualidade do produto (Brackett, 1992; Hurst, 1995), sendo a lavagem com água clorada recomendada (Madden, 1992).

Com objetivo de ampliar o conhecimento e atender as novas demandas do mercado por hortaliças minimamente processadas, estes trabalho se propôs a testar diferentes tempos de sanitização e verificar seu efeito na qualidade de beterrabas minimamente processadas.

\subsection{Material e Métodos}

As raízes tuberosas, cv. Early Wonder, foram obtidas de um produtor da região de Piracicaba, SP. As raízes foram selecionadas quanto ao tamanho, firmeza, cor e formato, tendo sido descartadas raízes murchas e com defeitos ou injúrias. Estas foram pré-lavadas em água corrente com o objetivo de retirar as impurezas advindas do campo e colocadas em câmara fria a $10 \pm 1^{\circ} \mathrm{C}$ para serem minimamente processadas (vide ANEXO A).

$O$ produto foi descascado mecanicamente utilizando-se descascadora industrial (Shymsen) com disco abrasivo e imerso em água resfriada $\left(5 \pm 0,5^{\circ} \mathrm{C}\right)$ por 2 minutos. A função desta imersão em água resfriada foi de manter baixa a 
atividade metabólica do produto. A seguir, as raízes foram submetidas a etapa de corte em forma de retalhos. Utilizou-se uma processadora (Robot Coupe) com disco de espessura de $2 \mathrm{~mm}$. Após o corte, o material foi separado em 5 lotes e sanitizado por 0 (controle), 3, 6, 9 e 12 minutos em água clorada (200ppm de cloro ativo), com o objetivo de reduzir riscos de contaminação, e em seguida enxaguado por 1 minuto (em água com 3ppm de cloro ativo) para a retirada do excesso de cloro. O sanitizante utilizado, em ambas as etapas, foi o SUMAVEG. Este produto tendo como princípio ativo o Dicloro-S-Triazinatriona Sódica Diidratada e é fabricado pela Diversey Lever-Indústrias Gessy Lever Ltda.

O produto minimamente processado foi centrifugado (2000 rpm) em centrífuga doméstica (ARNO) durante 1 minuto para a retirada do excesso de água.

Todos os tratamentos foram acondicionados em bandejas de poliestireno expandido, nas dimensões $14 \times 20 \mathrm{~cm}$ de largura e comprimento, respectivamente, envolvidas por filme de policloreto de vinila (PVC), com 14 micras de espessura e armazenados a $5 \pm 1^{\circ} \mathrm{C}$ e $85 \pm 5 \%$ UR.

O período de armazenamento foi de 10 dias, sendo que as avaliações físico-químicas e sensoriais foram realizadas a cada 2 dias. As variáveis físicoquímicas e sensoriais analisadas foram: a) teor de sólidos solúveis totais: por leitura direta em refratômetro digital (Atago), utilizando-se uma gota de raiz centrifugada em centrífuga doméstica. Os resultados foram expressos em ${ }^{\circ}$ Brix. b) cor: determinada com colorímetro (Minolta), determinando-se os valores de $\mathrm{L}$ $a^{*} b^{*}$ e calculando-se 0 índice de cor (IC) através da fórmula $I C=1000 \times a^{*} / L \times b^{*}$ (Mazzuz, 1996). Segundo o autor o IC varia de $-20 \mathrm{a}+20$ sendo que, quanto mais positivo, mais intenso é o vermelho. As leituras foram realizadas diretamente sobre o produto minimamente processado. c) teores de betacianina e betaxantina: a metodologia utilizada foi adaptada de Nilson (1970), onde $2 \mathrm{~g}$ de amostras previamente congeladas foram maceradas em $5 \mathrm{~mL}$ de água destilada. A solução foi colocada em tubetes e centrifugada em centrífuga 
refrigerada (Sorvall) a $4^{\circ} \mathrm{C}$ (15000rpm) durante 40 minutos. Num tubo de ensaio foram homogenizados $1 \mathrm{~mL}$ do sobrenadante e $24 \mathrm{~mL}$ de água destilada. Foram feitas leituras das amostras a $476 \mathrm{~nm}, 538 \mathrm{~nm}$ e $600 \mathrm{~nm}$. Os cálculos foram feitos através das seguintes fórmulas: $x=1,095(a-c), y=b-z-x / 3,1$ e $z=a-x$, sendo: $a=$ leitura da amostra $(538 \mathrm{~nm}) ; \mathrm{b}=$ leitura da amostra $(476 \mathrm{~nm}) ; \mathrm{c}=$ leitura da amostra $(600 \mathrm{~nm}) ; \mathrm{x}=$ absorção de betacianina; $y=$ absorção de betaxantina; $z=$ absorção de impurezas. d) avaliação sensorial (aparência global): foi realizada por uma equipe de 10 analisadores treinados utilizando-se uma escala de notas adaptada de Peryam \& Girarddot (1952), onde: $9=$ excelente; $7=$ bom; $5=$ regular; $3=$ =ruim; 1=péssimo. A descrição das notas foram: $9=$ beterraba com aspecto de frescor e ausência de esbranquiçamento; $7=$ beterraba com aspecto de frescor, porém com leve esbranquiçamento; $5=$ beterraba com pouco aspecto de frescor e moderado esbranquiçamento; $3=$ beterraba sem aspecto de frescor, elevado esbranquiçamento; 1=beterraba totalmente desidratada e esbranquiçada. A nota 5 foi considerada como limite de comercialização (vide ANEXO B).

As análises microbiológicas foram realizadas no dia do processamento e no 6ำ dia de armazenamento.

A microbiota contaminante da beterraba minimamente processada foi avaliada pela contagem total de bactérias psicrotróficas, número mais provável (NMP) de coliformes totais e fecais e presença/ausência de Salmonella.

As análises foram efetuadas em porções 20 gramas de raízes para cada repetição, pesadas assepticamente e colocadas em erlenmeyers, com $180 \mathrm{~mL}$ de água peptonada $(0,1 \%)$ estéril, constituindo a diluição $10^{-1}$. A partir da diluição $10^{-1}$, obteve-se a diluição $10^{-2}$, pipetando-se $10 \mathrm{~mL}$ da solução $10^{-1} \mathrm{em}$ $90 \mathrm{~mL}$ de água peptonada esterelizada $(0,1 \%)$ e a partir desta, obteve-se a diluição $10^{-3}$ e assim sucessivamente.

A determinação da presença de Salmonella foi a única análise que dispensou o uso de diluições, por ter sido empregada uma metodologia distinta (descrita posteriormente). 
Contagem total de bactérias psicrotróficas:

Para contagem de bactérias psicrotróficas utilizou-se o meio Ágar Padrão para Contagem (PCA).

A partir da diluição $10^{-1}$ até a $10^{-5}$ das beterrabas minimamente processadas, foram plaqueados em profundidade, $1 \mathrm{~mL}$ de cada diluição em duplicata, utilizando-se $20 \mathrm{~mL}$ de meio de cultivo PCA. Após o plaqueamento, as placas permaneceram em repouso até completa solidificação do meio, sendo, então invertidas e incubadas a $7^{\circ} \mathrm{C}$ por 10 dias (vide ANEXO C).

Decorrido o tempo de incubação foram selecionadas as placas e fez-se a contagem das mesmas, com auxílio do contador de colônias tipo Quebec.

NMP de coliformes totais e fecais:

Coliformes totais e fecais foram determinados pelo método do NMP, através da técnica dos Tubos Múltiplos (vide ANEXO D).

Para o teste presuntivo foram utilizadas séries de três tubos de ensaio, os quais continham um tubo de Durham e Caldo Lactosado (CL).

A primeira série contou com tubos em dupla concentração, uma vez que, nessa série, foram adicionados $10 \mathrm{~mL}$ do inóculo, da diluição $10^{-1}$, evitando-se assim, uma diluição excessiva do caldo (meio de cultivo). As demais séries continham CL em concentração normal, sendo que em cada tubo da segunda série, adicionou-se $1 \mathrm{~mL}$ da diluição $10^{-1} \mathrm{e}$, em cada tubo da terceira série, adicionou-se $1 \mathrm{~mL}$ da diluição $10^{-2}$.

Todos os tubos foram incubados em estufa termostatizada a $35-37^{\circ} \mathrm{C}$, por 24-48h. Após 24 e 48 horas de incubação, sendo positivos os resultados, foi possível observar o esvaziamento dos tubos de Durham, devido àprodução de gás pelas bactérias do grupo coliforme ao fermentarem a lactose.

Alíquotas dos tubos positivos do teste presuntivo foram transferidas para o teste confirmativo, verificando-se, assim, se realmente, tratavam-se de bactérias do grupo coliforme. 
Utilizando-se a alça de níquel-cromo, foram inoculados tubos de Caldo Verde Brilhante Lactose Bile (CVBLB), em concentração simples, e tubos de Caldo EC, correspondentes aos tubos positivos da fase anterior.

Os tubos de CVBLB foram incubados em estufa termostatizada à temperatura de $35-37^{\circ} \mathrm{C}$ durante $24-48 \mathrm{~h}$, sendo verificada, após esse período a formação ou não de gás nos tubos de Durham.

Os tubos de EC, uma vez inoculados, foram incubados em banho-maria termostatizado àtemperatura de $45^{\circ} \mathrm{C}$ por 24 horas.

A partir do número de tubos positivos em cada série de ambos os meios, consultando-se seus valores correspondentes na Tabela da Associação Brasileira de Normas Técnicas MB 3463 (vide ANEXO E), obteve-se o NMP de coliformes totais (CVBLB) e fecais (Caldo EC), por g de beterraba ralada.

\section{Detecção de Salmonella:}

Para detecção de Salmonella, utilizou-se o Kit '1-2 test', fabricado pela BioControl/USA. Foi feito um pré-enriquecimento de cada amostra analisada, inoculando-se $25 \mathrm{~g}$ de beterraba ralada em um erlenmeyer contendo $225 \mathrm{~mL}$ de água peptonada tamponada esterilizada. Os frascos foram incubados em estufa termostatizada, a 35으 por 24 horas. Decorrido o período de incubação fez-se o preparo dos kits, inoculando $0,1 \mathrm{~mL}$ da amostra. Incubou-se os kits a $35^{\circ} \mathrm{C}$ por 24 horas. Após a incubação foi feita a leitura dos resultados. A possível presença de Salmonella é caracterizada pela formação de uma imunobanda na metade superior do gel. Trata-se de uma banda branca que apresenta forma de U formada pela aglutinação das células da bactéria.

O delineamento experimental utilizado foi inteiramente ao acaso em esquema fatorial $5 \times 6$ ( 5 tempos de sanitização e 6 períodos de avaliação) para as análises físico-químicas. Utilizaram-se 4 repetições com aproximadamente $150 \mathrm{~g}$ de raízes minimamente processadas por bandeja. Os resultados das análises fisico-químicas foram submetidos à análise do desvio padrão, onde as 
diferenças entre dois tratamentos maior que a soma de dois desvios padrões foram consideradas significativas ( $P$ 0,05) (Moretti et al., 2002a). Para avaliação dos padrões microbiológicos os resultados foram expressos em UFC/g de produto para bactérias psicrotróficas, NMP/g de produto para coliformes totais e fecais e presença ou ausência de Salmonella em $25 \mathrm{~g}$ de produto.

\subsection{Resultados e Discussão}

No 6을 dia de armazenamento todos os tratamentos atingiram nota 5 , ou seja, nota limite de comercialização (Figura 1). Após 8 dias todas as parcelas receberam nota 3 , considerada aparência global ruim. Portanto, o tempo de vida útil para beterrabas minimamente processadas é de 6 dias. De maneira geral, beterrabas minimamente processadas sem sanitização apresentaram-se de coloração vermelha mais intensa durante o armazenamento. Entretanto, este tratamento controle não é recomendado devido ao fato de que a sanitização é uma operação importante e indispensável no processamento mínimo, como forma de reduzir a contaminação microbiana (Oliveira \& Valle, 2000). 


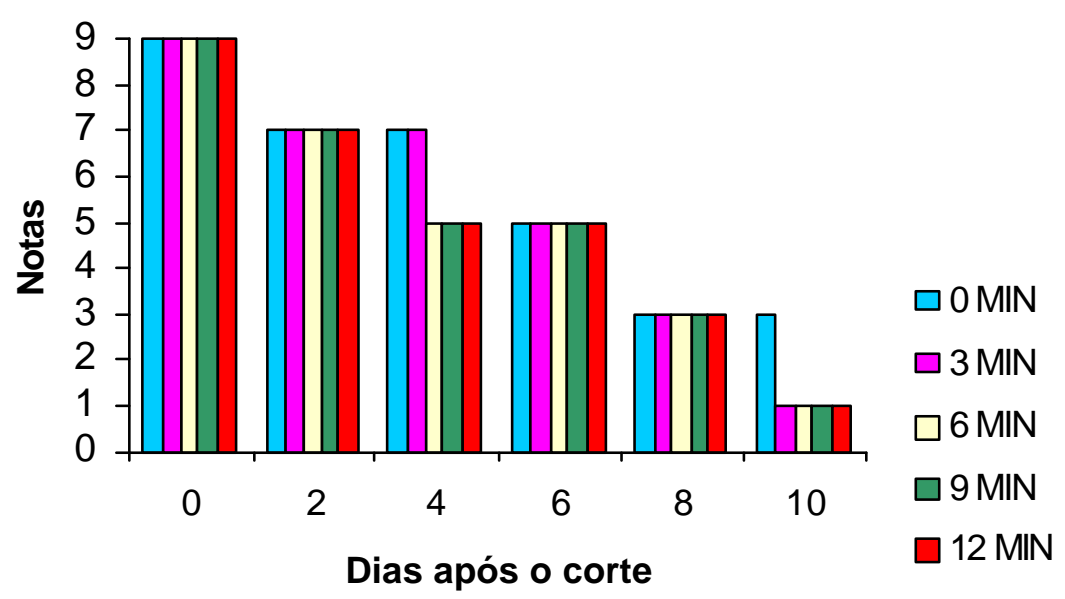

Figura 1 - Análise sensorial de beterrabas minimamente processadas submetidas a diferentes tempos de sanitização e armazenadas a $5 \pm 1^{\circ} \mathrm{C}$ e $85 \pm 5 \%$ UR. (Notas: $9=$ excelente; $7=$ bom; $5=$ regular; 3=ruim; 1=péssimo).

O tecido esbranquiçado que se forma na superfície, semelhante ao que ocorre em cenoura minimamente processada (denominada "white blush"), torna o produto com aparência envelhecida e não atraente. Enquanto para alguns pesquisadores o esbranquiçamento é resultado da desidratação das células superficiais danificadas pelo pré-processamento (Avena-Bustillos et al., 1994; Tatsumi et al., 1993), para outros é devido à formação de lignina na superfície dos cortes (Bolin \& Huxsoll, 1991). Outros ainda consideram que o esbranquiçamento é causado pela combinação dos dois processos, a desidratação e a formação de lignina (Cisneros-Zevallos et al., 1995). 

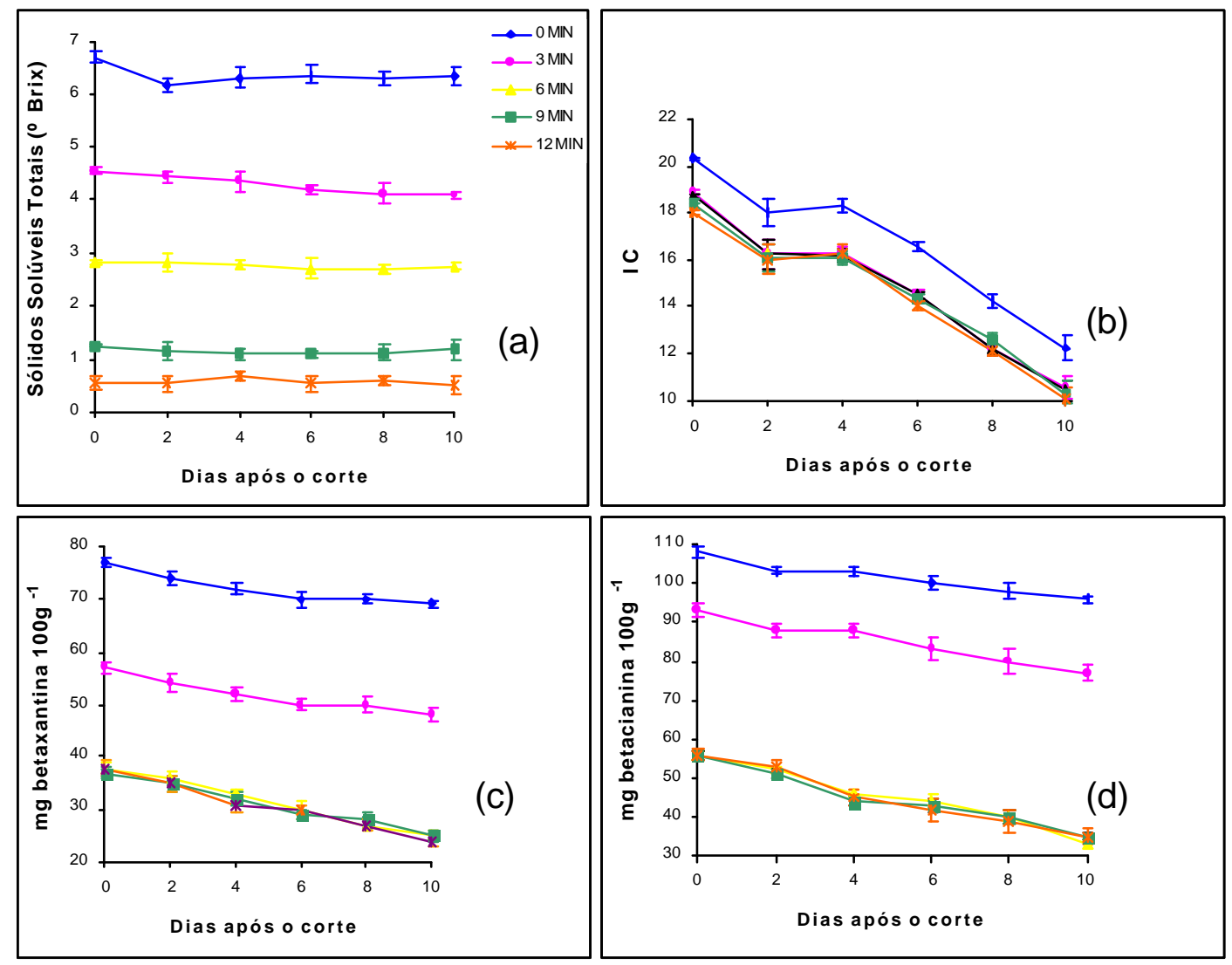

Figura 2 - Teor de sólidos solúveis totais (a), Índice de cor (b), teor de betaxantina (c) e teor de betacianina (d) de beterrabas minimamente processadas submetidas a diferentes tempos de sanitização e armazenadas a $5 \pm 1^{\circ} \mathrm{C}$ e $85 \pm 5 \%$ UR. Barras verticais indicam o desvio padrão da média.

Futuros estudos devem ser realizados visando esclarecer estas dúvidas. A desidratação se reflete em uma mudança de cor reversível que é tanto mais acentuada quanto maior a perda de água, enquanto a ativação de metabolismo fenólico e a produção de lignina resultam em uma mudança de cor irreversível (Izumi et al., 1996).

As beterrabas minimamente processadas não sanitizadas apresentaram os maiores teores de sólidos solúveis, sendo que quanto maior o tempo de sanitização menor foi o teor de sólidos solúveis nas raízes (Figura 2a). Estas 
diferenças ocorreram em função do maior tempo de contato das superfícies de corte das raízes com a água, o que fez extravazar mais conteúdo celular, incluindo os carboidratos solúveis (componente dos sólidos solúveis) que se dissolveram na água de sanitização.

As beterrabas minimamente processadas e não sanitizadas apresentaram os maiores valores de IC (índice de cor), durante o período de armazenamento (Figura $2 b$ ). A maior intensidade de coloração para o produto não sanitizado era esperado, considerando que os pigmentos de betalaínas, que são solúveis em água, não entraram em contato com a mesma. Para os demais tratamentos não houve diferença significativa para os valores de IC. Em todos os tratamentos houve uma redução gradativa nos valores de IC com o decorrer do período de armazenamento.

O teor de betaxantina foi maior durante todo armazenamento para beterrabas não sanitizadas (Figura 2c). Raízes minimamente processadas dos tratamentos com 6, 9 e 12 minutos de sanitização não diferiram significativamente entre si durante o experimento, alcançando os menores valores para os teores deste pigmento.

Poucos estudos referente aos teores de pigmentos em beterraba são encontrados na literatura. Nilson (1973) verificou que os teores de betaxantina presentes em diferentes cultivares de beterrabas intactas foram de 20-60, 60130 e $60-140 \mathrm{mg}^{100 \mathrm{~g}^{-1}}$ para as variedades Banco WW, Boltardy e Rubra, respectivamente.

O teor de betacianina teve comportamento semelhante ao teor de betaxantina. Beterrabas do controle obtiveram os maiores valores no teor de betacianina durante o armazenamento. De igual forma, os tratamentos com 6, 9 e 12 minutos não apresentaram diferença significativa durante o armazenamento (Figura 2d).

De acordo com Nilson (1973), o teor de betacianina varia em função da cultivar de beterraba. Para beterrabas intactas os teores de betacianina

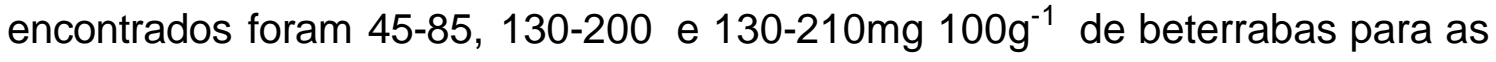


variedades Banco WW, Boltardy e Rubra, respectivamente. Sapers \& Hornstein (1979) também verificaram diferenças significativas no conteúdo de betacianina e betaxantina em diferentes variedades de beterraba de mesa.

De maneira geral foi observado uma perda gradual de pigmentos de betaxantina e betacianina durante $\mathrm{o}$ armazenamento (Figura $2 \mathrm{c}$ e d), concordando com os resultados obtidos por Osornio \& Chaves (1998), os quais verificaram em beterrabas raladas e armazenadas a $0^{\circ} \mathrm{C}$ que o teor de betalaína decresceu aproximadamente $40-50 \%$ após 7 dias. No caso de beterrabas minimamente processadas, os processos de sanitização e enxague favorecem uma maior perda destes pigmentos devido o contato da superfície das raízes com a água.

Em nenhum dos tratamentos foi detectado a presença de Salmonella no decorrer do período de armazenamento (Tabela 1). Estes resultados estão de acordo com a Resolução RDC №12 de 02 de janeiro de 2001, da Agência Nacional de Vigilância Sanitária do Ministério da Saúde que estabelece para hortaliças in natura a ausência de Salmonella (em $25 \mathrm{~g}$ de produto). 
Tabela 1. Detecção de Salmonella em $25 \mathrm{~g}$ de beterrabas minimamente processadas submetidas a diferentes tempos de sanitização e armazenadas a $5 \pm 1^{\circ} \mathrm{C}$ e $85 \pm 5 \%$ UR, utilizando-se o kit "1-2 test" da Bio Control/USA.

Tratamentos Dias após o corte

0

6

\begin{tabular}{lll}
\hline 0 minutos & Ausência & Ausência \\
3 minutos & Ausência & Ausência \\
6 minutos & Ausência & Ausência \\
9 minutos & Ausência & Ausência \\
12 minutos & Ausência & Ausência \\
\hline
\end{tabular}

A contagem de coliformes totais no dia do processamento foi maior para beterrabas não sanitizadas, atingindo valores na ordem de $>110 \mathrm{NMP} / \mathrm{g}$ de produto (Tabela 2) em ambos os dias de análise. Para os tratamentos 3 e 6 minutos de sanitização e 9 e 12 minutos de sanitização a contagem inicial de coliformes totais foi de $1,5 \mathrm{NMP} / \mathrm{g}$ e $0,91 \mathrm{NMP} / \mathrm{g}$ de produto, respectivamente. Foi verificado no $6^{0}$ dia de armazenamento, quando os tratamentos atingiram nota limite de comercialização, que as beterrabas de todos os tratamentos que sofreram a operação de sanitização apresentaram contagens de coliformes totais na ordem de $46 \mathrm{NMP} / \mathrm{g}$ de produto (Tabela 2 ). 
Tabela 2. NMP de coliformes totais de beterrabas minimamente processadas submetidas a diferentes tempos de sanitização e armazenadas a $5 \pm 1^{\circ} \mathrm{C}$ e $85 \pm 5 \%$ UR, utilizando-se a metodologia de tubos múltiplos.

\begin{tabular}{lcc}
\hline Tratamentos & \multicolumn{3}{c}{ Dias após o corte } \\
& & 6 \\
\hline 0 minutos & $>110$ & $>110$ \\
3 minutos & 1,5 & 46 \\
6 minutos & 1,5 & 46 \\
9 minutos & 0,91 & 46 \\
12 minutos & 0,91 & 46 \\
\hline
\end{tabular}

Os resultados obtidos representam o NMP de coliformes totais/g de produto.

Durante o armazenamento, não foi detectado presença de coliformes fecais(Tabela 3) nos tratamentos avaliados que foram submetidos a etapa de sanitização. O tratamento controle (sem santitização) apresentou coliformes fecais em ambos os dias de análise, comprovando, portanto, a importância da operação de sanitização nesses produtos. Na metodologia de tubos múltiplos, resultado menor que $0,3 \mathrm{NMP} / \mathrm{g}$ significa que nenhum dos tubos inoculados se mostrou positivo. 
Tabela 3. NMP de coliformes fecais de beterrabas minimamente processadas submetidas a diferentes tempos de sanitização e armazenadas a $5 \pm 1^{\circ} \mathrm{C}$ e $85 \pm 5 \%$ UR, utilizando-se a metodologia de tubos múltiplos.

Tratamentos Dias após o corte

0

6

\begin{tabular}{lcc}
\hline 0 minutos & 0,36 & 0,91 \\
3 minutos & $<0,3$ & $<0,3$ \\
6 minutos & $<0,3$ & $<0,3$ \\
9 minutos & $<0,3$ & $<0,3$ \\
12 minutos & $<0,3$ & $<0,3$ \\
\hline
\end{tabular}

Os resultados obtidos representam o NMP de coliformes fecais/g de produto.

Para produtos minimamente processados, ainda não existe uma legislação determinando os limites de contagens permitidas. Entretanto, estes resultados estão de acordo com a resolução RDC no 12 de 02 de janeiro de 2001 da Agência Nacional de Vigilância Sanitária do Ministério da Saúde, que estabelece como padrão o máximo de $10^{2} \mathrm{NMP}$ de coliformes fecais/g de hortaliça fresca.

A contagem total das bactérias psicrotróficas aumentou com o decorrer dos dias de armazenamento para todos tratamentos (Tabela 4). A beterrabas do controle apresentaram as maiores contagens de bactérias psicrotróficas em ambos os dias de análise. Para os tratamentos com sanitização, verificou-se que quanto maior o tempo de sanitização menor a contagem de bactérias psicrotróficas. $\mathrm{O}$ aumento na população de bactérias psicrotróficas também foi verificado em repolhos minimamente processados, de $10^{2}$ para $10^{5} \mathrm{UFC} / \mathrm{g}$, nas amostras mantidas a $4^{\circ} \mathrm{C}$, após o quarto dia de armazenamento (Piagentini et al., 1997). 
Tabela 4. Contagem total de bactérias psicrotróficas de beterrabas minimamente processadas submetidas a diferentes tempos de sanitização e armazenadas a $5 \pm 1^{\circ} \mathrm{C}$ e $85 \pm 5 \%$ UR, segundo a metodologia convencional (PCA).

\section{Tratamentos}

Dias após o corte

0

6

0 minutos

$1,37 \times 10^{3}$

$3,80 \times 10^{5}$

3 minutos

$4,30 \times 10^{2}$

$3,36 \times 10^{4}$

6 minutos

$2,65 \times 10^{2}$

$2,20 \times 10^{4}$

9 minutos

$2,14 \times 10^{2}$

$7,70 \times 10^{3}$

12 minutos

$1,82 \times 10^{2}$

$6,24 \times 10^{3}$

Os resultados obtidos representam a quantidade de UFC(unidade formadora de colônia)/g de produto.

Conforme verificado no presente experimento, ocorreu uma redução gradativa na coloração das raízes durante o armazenamento para todos os tratamentos. A redução na intensidade de coloração, aparentemente, se deve a alteração nos teores de pigmentos, já que estes foram perdidos também gradativamente com o decorrer dos dias de armazenamento. Verificou-se o aparecimento de desidratação e esbranquiçamento nas raízes de todos os tratamentos durante o experimento, o que reduz a intensidade da cor vermelha na superfície do corte. Os teores de sólidos solúveis totais variaram para todos os tempos de sanitização.

Os resultados obtidos nas análises microbiológicas de todos os tratamentos estão dentro do padrão aceitável, mesmo sendo verificado o aparecimento de coliformes fecais no tratamento controle. Apesar do tratamento controle ter apresentado uma coloração vermelho mais intensa e menor perda 
de pigmentos durante o armazenamento ele não é recomendado devido ao fato da sanitização ser uma operação indispensável durante o manuseio, como forma de reduzir a contaminação microbiana do produto. Portanto conclui-se que o tempo de sanitização de 3 minutos é o melhor para a manutenção da qualidade de beterrabas minimamente processadas, onde a perda de cor e pigmentos foi menor em relação ao controle e levou o produto com padrões microbiológicos que se enquadram na legislação vigente no país para as hortaliças frescas.

\subsection{Conclusão}

A partir dos resultados obtidos, pode concluir-se que:

$\checkmark$ O tempo de sanitização de 3 minutos é o mais recomendado para beterrabas minimamente processadas, mantendo estas dentro dos padrões microbiológicos da legislação atual e proporcionando o armazenamento do produto durante 6 dias a $5^{\circ} \mathrm{C}$. 


\section{MOMENTO DE SANITIZAÃO PARA BETERRABAS MINIMAMENTE PROCESSADAS}

\section{Resumo}

Raízes de beterrabas, cv. Early Wonder, foram minimamente processadas e submetidas a diferentes tratamentos de sanitização: controle (sem sanitização), sanitização após o corte (padrão), sanitização antes da pelagem e após o corte, sanitização apenas após a pelagem, sanitização antes e após a pelagem, sanitização antes e após a pelagem, e após o corte. Após os tratamentos, o produto foi colocado em bandejas envoltas com filme de PVC e armazenado a $5 \pm 1^{\circ} \mathrm{C}$ e $85 \pm 5 \%$ UR durante 10 dias. Realizou-se análises físicoquímicas, sensoriais e microbiológicas durante o armazenamento refrigerado. Não foi detectada a presença de coliformes fecais e Salmonella nos tratamentos com etapa de sanitização. As contagens de coliformes totais e bactérias psicrotróficas foram maiores para beterrabas não sanitizadas. Houve um decréscimo nos teores dos pigmentos durante conservação. Os teores de betacianina e betaxantina foram maiores para beterrabas não sanitizadas. De maneira geral, as características sensoriais foram pouco influenciadas pelos tratamentos, diferindo apenas na intensidade da coloração característica sendo esta mais intensa nos tratamentos que não apresentaram sanitização após o corte. A sanitização após a pelagem é a mais apropriada para manutenção da qualidade por reduzir a perda de pigmentos e garantir a segurança alimentar do produto, além de evitar o desperdício de cloro. 
Palavras-chave: Beta vulgaris L., pigmentos, processamento mínimo, microbiologia.

\section{SANITIZATION MOMENT FOR FRESH-CUT BEET ROOTS}

\section{Summary}

Early Wonder beet roots were minimally processed and submitted to different sanitization treatments: control (no sanitization), sanitization after cutting (standard), sanitization before peeling and after cutting, sanitization only after peeling, sanitization before and after peeling, sanitization before and after peeling and after cut. After the treatments, the product was placed on trays wrapped in PVC film and stored at $5 \pm 1^{\circ} \mathrm{C}$ and $85 \pm 5 \% \mathrm{RH}$ for 10 days. Sensory, physicochemical and microbiological analyses were conducted during refrigerated storage. Fecal coliforms and Salmonella were not detected in beet roots that underwent sanitization. Total coliforms and psychotropic bacteria counts, as well as betacyanin and betaxanthin amounts were higher in nonsanitized beet roots. There was a decrease in pigment amounts during storage. Generally, treatments had little influence on sensory characteristics, except for the specific color that was more intense in beet roots non-sanitized after cutting. Post-peeling sanitization is the most suitable for quality maintenance, as it reduces pigment loss, ensures good food safety standards and avoids chlorine waste.

Key-words: Beta vulgaris L., pigments, minimally processing, microbiology. 


\subsection{Introdução}

O consumo de produtos minimamente processados tem tido considerável aumento nos últimos anos, em função do maior interesse dos consumidores por produtos cada vez mais naturais e convenientes (Durigan \& Sargent, 1999), e também pela maior participação da mulher no mercado de trabalho, envelhecimento da população e aumento na importância das refeições coletivas (Moretti, 2001).

O processamento mínimo usualmente descreve um produto fresco, adequadamente descascado, fatiado ou cortado, 100\% comestível, contrastando com æ̀ técnicas de processamento convencionais as quais incluem congelamento, enlatamento, secagem, etc (Bolin \& Huxsoll, 1989).

Dentre as hortaliças minimamente processadas no Brasil, a beterraba vem aumentando a sua importância. A beterraba é uma raiz tuberosa de cor vermelho-arroxeada devido à presença de betalaínas. As betalaínas são pigmentos hidrossolúveis e estão divididas em duas classes: betacianina (cor avermelhada) e betaxantina (cor amarelada), caracterizando a coloração típica das raízes. Estes pigmentos, além de fornecerem cor à beterraba, são importantes substâncias antioxidantes para a dieta humana (Kanner et al., 2001).

Um dos principais problemas tecnológicos observados em beterraba é a descoloração do produto minimamente processado. As operações de lavagem, sanitização e enxague, realizadas após o corte, favorecem a perda de betalaínas, devido a estes pigmentos serem solúveis em água (Nilson, 1970). Entretanto, estes procedimentos são de suma importância dentro do fluxograma de preparo de beterraba minimamente processada, como forma de reduzir a contaminação microbiana e os riscos de toxinfecções alimentares.

Visando um melhor aproveitamento, a agregação de valor e aumento de conveniência para o consumo, o presente trabalho teve como objetivo estudar 
diferentes momentos de sanitização e verificar seu efeito na qualidade de beterraba minimamente processada.

\subsection{Material e Métodos}

\section{Obtenção do material experimental}

As beterrabas, cv. Early Wonder, colhidas na região de Piracicaba-SP, foram levadas para o Laboratório de Pós-Colheita do Departamento de Produção Vegetal da ESALQ/USP onde foram selecionadas quanto ao tamanho, firmeza, cor e formato, tendo sido descartadas raízes murchas, e com defeitos e injúrias. Estas foram pré-lavadas em água corrente com o objetivo de retirar as impurezas advindas do campo (vide ANEXO A). A seguir, o material experimental foi separado em seis lotes, com os seguintes tratamentos:

T1 - sem sanitização, só pré-lavagem (Controle)

T2 - sanitização após o corte (Padrão)

T3 - sanitização antes da pelagem e após o corte

T4 - sanitização apenas após a pelagem

T5 - sanitização antes e após a pelagem

T6 - sanitização antes e após a pelagem, e após o corte

Em todos os tratamentos a etapa de sanitização veio acompanhada da etapa de enxague.

\section{Processamento mínimo}

As etapas de processamento mínimo ocorreram dentro da câmara fria $\left(10 \pm 1^{\circ} \mathrm{C}\right)$ sobre mesa de aço inoxidável devidamente higienizada. Os operadores utilizaram roupas protetoras (botas, aventais, luvas, máscaras e toucas), como parte das condições mínimas de assepsia.

As etapas de processamento, dependendo do tratamento foram:

a) Descascamento (pelagem): O produto foi descascado mecanicamente por descascadora industrial (Shymsen) com disco abrasivo para retirada da película externa das raízes. 
b) Lavagem e pré-resfriamento: as raízes foram imersas em água resfriada $\left(5 \pm 0,5^{\circ} \mathrm{C}\right)$ por 2 minutos. A função desta imersão em água resfriada foi a de manter baixa a atividade metabólica do produto.

c) Corte: as beterrabas foram submetidas a etapa de corte em forma de retalhos. Utilizou-se uma processadora industrial (Robot Coupe) com disco de espessura de $2 \mathrm{~mm}$.

d) Sanitização: o material foi sanitizado via imersão por 6 minutos em água clorada (200ppm de cloro ativo), com o objetivo de reduzir riscos de contaminação microbiana O sanitizante utilizado foi o SUMAVEG. Este produto tem como principio ativo o Dicloro-S-Triazinatriona Sódica Diidratada e é fabricado pela Diversey Lever-Indústrias Gessy Lever Ltda.

e) Enxague: as raízes foram enxaguadas através de imersão por 1 minuto (em água com 3ppm de cloro ativo) para a retirada do excesso de cloro. O mesmo sanitizante foi utilizado.

f) Centrifugação: realizada em centrífuga doméstica (ARNO) durante 1 minuto para a retirada do excesso de água do produto, com velocidade de 2000rpm.

g) Armazenamento: as raízes foram armazenadas a $5 \pm 1^{\circ} \mathrm{C}$ e $85 \pm 5 \%$ UR durante 10 dias, em bandejas de poliestireno expandido, com dimensões $14 \times 20 \mathrm{~cm}$ de largura e comprimento, respectivamente, envoltas em filmes de PVC (policloreto de vinila) com $14 \mu \mathrm{m}$ de espessura.

\section{Determinações}

As variáveis físico-químicas e sensoriais analisadas foram: a) teor de sólidos solúveis totais: por leitura direta em refratômetro digital (Atago), utilizando-se uma gota de raiz homogeneizada em centrífuga doméstica. Os resultados foram expressos em ํㅜㅅ. b) cor: determinada com colorímetro (Minolta), determinando-se os valores de $\mathrm{L} \mathrm{a}^{*} \mathrm{~b}^{*} \mathrm{e}$ calculando-se o índice de cor (IC) através da fórmula IC=1000xa*/Lxb* (Mazzuz, 1996). Segundo o autor o IC varia de $-20 \mathrm{a}+20$ sendo que quanto mais positivo mais intenso é o vermelho (Mazzuz, 1996). As leituras foram realizadas diretamente sobre o produto 
minimamente processado. c) teores de betacianina e betaxantina: a metodologia utilizada foi adaptada de Nilson (1970), onde $2 \mathrm{~g}$ de amostra previamente congeladas foram maceradas em $5 \mathrm{~mL}$ de água destilada. A solução foi colocada em tubetes e centrifugada utilizando-se centrífuga refrigerada (Sorvall) a $4^{\circ} \mathrm{C}$ (15000rpm) durante 40 minutos. Num tubo de ensaio foram homogenizados $1 \mathrm{~mL}$ do sobrenadante e $24 \mathrm{~mL}$ de água destilada. Foram feitas leituras das amostras a $476 \mathrm{~nm}, 538 \mathrm{~nm}$ e $600 \mathrm{~nm}$. Os cálculos foram feitos através das seguintes fórmulas: $x=1,095(a-c), y=b-z-x / 3,1$ e $z=a-x$, sendo: $a=$ leitura da amostra $(538 \mathrm{~nm}) ; \mathrm{b}=$ leitura da amostra $(476 \mathrm{~nm}) ; \mathrm{c}=$ leitura da amostra $(600 \mathrm{~nm})$; $x=$ absorção de betacianina; $y=$ absorção de betaxantina; $z=$ absorção de impurezas. d) avaliação sensorial (aparência global): foi realizada por uma equipe de 10 analisadores treinados utilizando-se uma escala de notas adaptada de Peryam \& Girarddot (1952), onde: $9=$ excelente; $7=$ bom; $5=$ regular; $3=$ ruim; 1=péssimo. A descrição das notas foram: $9=$ beterraba com aspecto de frescor e ausência de esbranquiçamento; $7=$ beterraba com aspecto de frescor, porém com leve esbranquiçamento; 5 =beterraba com pouco aspecto de frescor e moderado esbranquiçamento; $3=$ beterraba sem aspecto de frescor, elevado esbranquiçamento; 1=beterraba totalmente desidratada e esbranquiçada. A nota 5 foi considerada como limite de comercialização (vide ANEXO B).

As análises microbiológicas foram realizadas no dia do processamento e no 6 o dia de armazenamento.

A microbiota contaminante da beterraba minimamente processada foi avaliada pela contagem total de bactérias psicrotróficas, número mais provável (NMP) de coliformes totais e fecais e presença/ausência de Salmonella.

As análises foram efetuadas em porções 20 gramas de raízes para cada repetição, pesadas assepticamente e colocadas em erlenmeyers, com $180 \mathrm{~mL}$ de água peptonada $(0,1 \%)$ estéril, constituindo a diluição $10^{-1}$. A partir da diluição $10^{-1}$, obteve-se a diluição $10^{-2}$, pipetando-se $10 \mathrm{~mL}$ da solução $10^{-1} \mathrm{em}$ 
$90 \mathrm{~mL}$ de água peptonada esterelizada $(0,1 \%)$ e a partir desta, obteve-se a diluição $10^{-3}$ e assim sucessivamente.

A determinação da presença de Salmonella foi a única análise que dispensou o uso de diluições, por ter sido empregada uma metodologia distinta (descrita posteriormente).

Contagem total de bactérias psicrotróficas:

Para contagem de bactérias psicrotróficas utilizou-se o meio Ágar Padrão para Contagem (PCA).

A partir da diluição $10^{-1}$ até a $10^{-5}$ das beterrabas minimamente processadas, foram plaqueados em profundidade, $1 \mathrm{~mL}$ de cada diluição em duplicata, utilizando-se $20 \mathrm{~mL}$ de meio de cultivo PCA. Após o plaqueamento, as placas permaneceram em repouso até completa solidificação do meio, sendo, então invertidas e incubadas a $7^{\circ} \mathrm{C}$ por 10 dias (vide ANEXO C).

Decorrido o tempo de incubação foram selecionadas as placas e fez-se a contagem das mesmas, com auxílio do contador de colônias tipo Quebec.

\section{NMP de coliformes totais e fecais:}

Coliformes totais e fecais foram determinados pelo método do NMP, através da técnica dos Tubos Múltiplos (vide ANEXO D).

Para o teste presuntivo foram utilizadas séries de três tubos de ensaio, os quais continham um tubo de Durham e Caldo Lactosado (CL).

A primeira série contou com tubos contendo o meio em dupla concentração, uma vez que, nessa série, foram adicionados $10 \mathrm{~mL}$ do inóculo, da diluição $10^{-1}$, evitando-se assim, uma diluição excessiva do caldo (meio de cultivo). As demais séries continham CL em concentração normal, sendo que em cada tubo da segunda série, adicionou-se $1 \mathrm{~mL}$ da diluição $10^{-1} \mathrm{e}$, em cada tubo da terceira série, adicionou-se $1 \mathrm{~mL}$ da diluição $10^{-2}$. 
Todos os tubos foram incubados em estufa termostatizada a $35-37^{\circ} \mathrm{C}$, por 24-48h. Após 24 e 48 horas de incubação, sendo positivos os resultados, foi possível observar o esvaziamento dos tubos de Durham, devido à produção de gás pelas bactérias do grupo coliforme ao fermentarem a lactose.

Alíquotas dos tubos positivos do teste presuntivo foram transferidas para o teste confirmativo, verificando-se, assim, se realmente, tratavam-se de bactérias do grupo coliforme.

Utilizando-se a alça de níquel-cromo, foram inoculados tubos de Caldo Verde Brilhante Lactose Bile (CVBLB), em concentração simples, e tubos de Caldo EC, correspondentes aos tubos positivos da fase anterior.

Os tubos de CVBLB foram incubados em estufa termostatizada à temperatura de $35-37^{\circ} \mathrm{C}$ durante $24-48 \mathrm{~h}$, sendo verificada, após esse período a formação ou não de gás nos tubos de Durham.

Os tubos de EC, uma vez inoculados, foram incubados em banho-maria termostatizado àtemperatura de $45^{\circ} \mathrm{C}$ por 24 horas.

A partir do número de tubos positivos em cada série de ambos os meios, consultando-se seus valores correspondentes na Tabela da Associação Brasileira de Normas Técnicas MB 3463 (vide ANEXO E), obteve-se o NMP de coliformes totais (CVBLB) e fecais (Caldo EC), por g de beterraba ralada.

\section{Detecção de Salmonella:}

Para detecção de Salmonella, utilizou-se o Kit '1-2 test', fabricado pela BioControl/USA. Foi feito um pré-enriquecimento de cada amostra analisada, inoculando-se $25 \mathrm{~g}$ de beterraba ralada em um erlenmeyer contendo $225 \mathrm{~mL}$ de água peptonada tamponada esterilizada. Os frascos foram incubados em estufa termostatizada, a 35ํㅡ $\mathrm{C}$ por 24 horas. Decorrido o período de incubação fez-se o preparo dos kits, inoculando $0,1 \mathrm{~mL}$ da amostra. Incubou-se os kits a $35^{\circ} \mathrm{C}$ por 24 horas. Após a incubação foi feita a leitura dos resultados. A possível presença de Salmonella é caracterizada pela formação de uma imunobanda na 
metade superior do gel. Trata-se de uma banda branca que apresenta forma de U formada pela aglutinação das células da bactéria.

\section{Análise dos resultados}

O delineamento experimental utilizado foi inteiramente ao acaso em esquema fatorial $6 \times 6$ ( 6 tratamentos e 6 períodos de avaliação) para as análises físico-químicas. Utilizaram-se 4 repetições com aproximadamente $150 \mathrm{~g}$ de raízes minimamente processadas. Os resultados das análises fisico-químicas foram submetidos à análise do desvio padrão, onde as diferenças entre dois tratamentos maior que a soma de dois desvios padrões foram consideradas significativas ( $P$ 0,05) (Moretti et al., 2002a). Para avaliação dos padrões microbiológicos os resultados foram expressos em UFC/g de produto para bactérias psicrotróficas, $\mathrm{NMP} / \mathrm{g}$ de produto para coliformes totais e fecais e presença ou ausência de Salmonella em $25 \mathrm{~g}$ de produto.

\subsection{Resultados e Discussão}

Após 4 dias de armazenamento os tratamentos controle, após a pelagem e antes e após a pelagem apresentavam coloração vermelho mais intensa do que os tratamentos em que pelo menos uma etapa de sanitização ocorreu após o corte (Figura 1). No 6o dia de armazenamento todos tratamentos atingiram nota 5, ou seja, nota limite de comercialização. Durante o processo de preparo dos produtos minimamente processados a etapa de sanitização é essencial, como forma de minimizar a deterioração e manter a qualidade do produto (Brackett, 1992; Hurst, 1995), sendo a lavagem com água clorada recomendada (Madden, 1992). 


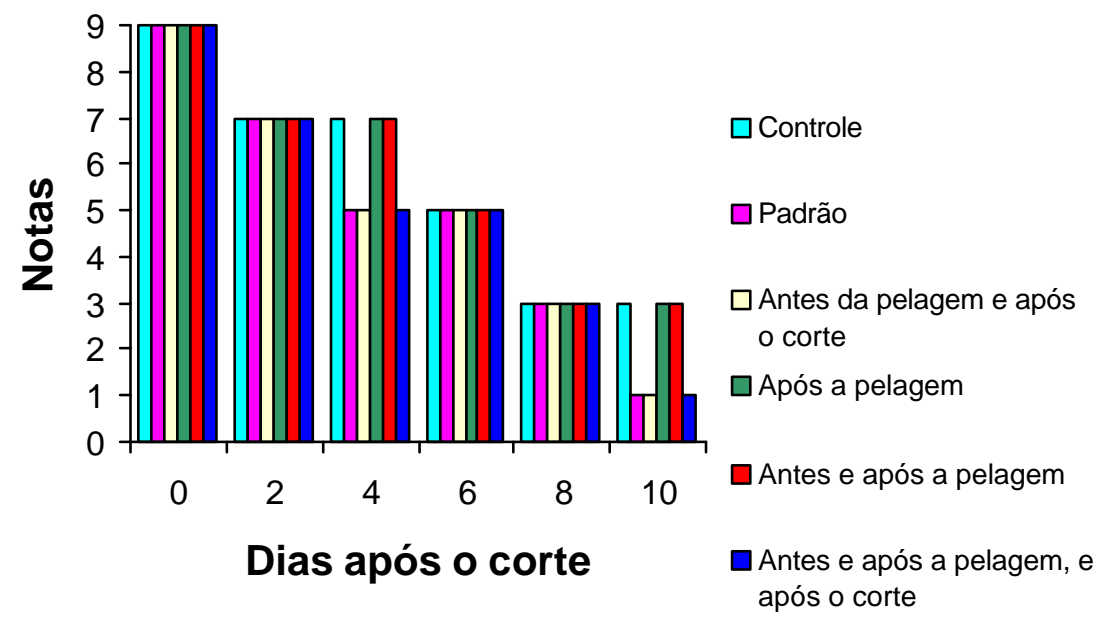

Figura 1 - Análise sensorial de beterrabas minimamente processadas submetidas a diferentes momentos de sanitização e armazenadas a $5 \pm 1^{\circ} \mathrm{C}$ e $85 \pm 5 \%$ UR. (Notas: 9=excelente; $7=$ bom; $5=$ regular; $3=$ ruim; $1=$ péssimo).

O tecido esbranquiçado que se forma na superfície, semelhante ao que ocorre em cenoura minimamente processada (denominada "white blush"), torna o produto com aparência envelhecida e não atraente. Enquanto para alguns autores o esbranquiçamento é resultado da desidratação das células superficiais danificadas pelo pré-processamento (Avena-Bustillos et al., 1994; Tatsumi et al., 1993). Para outros, é devido à formação de lignina na superfície dos cortes (Bolin \& Huxsoll, 1991). Para um terceiro grupo, o esbranquiçamento é causado pela combinação dos dois processos, a desidratação e a formação de lignina (Cisneros-Zevallos et al., 1995).

As beterrabas minimamente processadas do controle apresentaram os maiores teores de sólidos solúveis, sendo que as raízes minimamente processadas que tiveram pelo menos um dos momentos de sanitização após o corte tiveram valores menores no teor de sólidos solúveis (Figura 2a). Estas 
diferenças ocorreram em função da menor relação superfície/volume de corte das raízes com a água, o que fez extravazar mais conteúdo celular, incluindo os carboidratos solúveis (componente dos sólidos solúveis) que se dissolveram na água de sanitização.

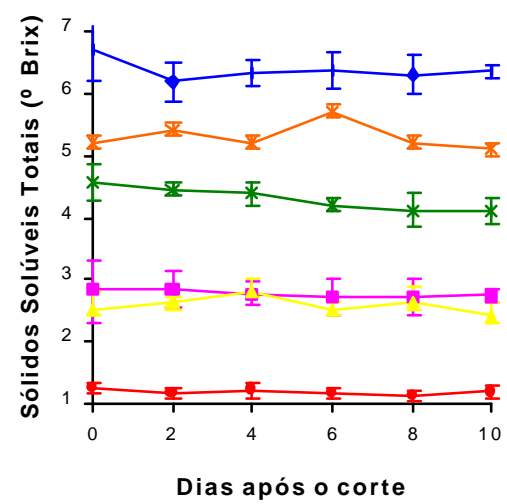

(a)
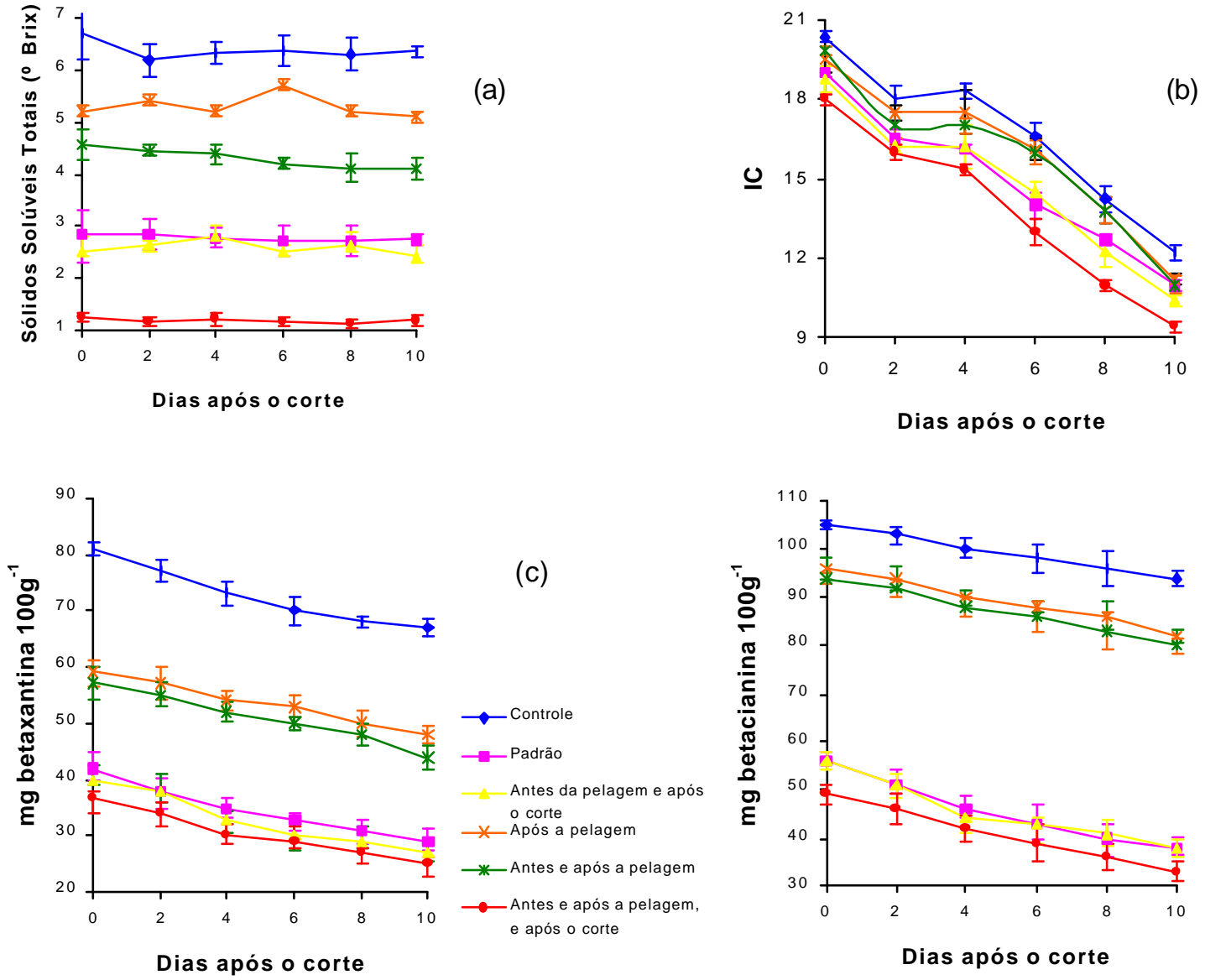

(d)

Figura 2 - Teor de sólidos solúveis totais (a), índice de cor (b), teor de betaxantina (c) e teor de betacianina (d) de beterrabas minimamente processadas submetidas a diferentes momentos de sanitização e armazenadas a $5 \pm 1^{\circ} \mathrm{C}$ e $85 \pm 5 \%$ UR. Barras verticais indicam o desvio padrão da média. 
As beterrabas minimamente processadas controle apresentaram os maiores valores de IC (índice de cor), durante o período de armazenamento (Figura 2b). A maior intensidade de coloração das raízes minimamente processadas foi verificada nos tratamentos que não sofreram sanitização após a etapa de corte. Isto já era esperado, considerando que os pigmentos de betalaínas, que são solúveis em água, não entraram em contato com a mesma. Em todos os tratamentos houve uma redução gradativa nos valores de IC com o decorrer do período de armazenamento, devido à descoloração superficial do produto.

O teor de betaxantina foi maior durante todo armazenamento para beterrabas controle (Figura 2c). Raízes minimamente processadas dos tratamentos com pelo menos um dos momentos de sanitização após o corte apresentaram os menores valores e não dferiram significativamente entre si durante o experimento.

O teor de betacianina teve comportamento semelhante ao teor de betaxantina. As beterrabas do controle obtiveram os maiores valores no teor de betacianina durante o armazenamento. De igual forma, raízes minimamente processadas dos tratamentos com pelo menos um dos momentos de sanitização após o corte apresentaram os menores valores e não diferiram significativamente entre si durante o experimento (Figura 2d).

Poucos estudos referentes aos teores de pigmentos em beterraba são encontrados na literatura. Sapers \& Hornstein (1979) verificaram diferenças significativas no conteúdo de betacianina e betaxantina em diferentes variedades de beterraba de mesa. De acordo com Nilson (1973), o teor de betacianina e betaxantina em beterraba varia em função da cultivar. Segundo o autor, os teores de betacianina e betaxantina, podem variar de 45-210 e 20$140 \mathrm{mg} 100^{-1}$, respectivamente.

De maneira geral, foi observado uma perda gradual de pigmentos de betaxantina e betacianina durante 0 armazenamento (Figura $2 c \quad e \quad d$ ), 
concordando com os resultados obtidos por Osornio \& Chaves (1998), os quais verificaram em beterrabas raladas e armazenadas a $0^{\circ} \mathrm{C}$ que o teor de betalaína decresceu aproximadamente $40-50 \%$ após 7 dias. Os pigmentos de betalaínas são mais solúveis em água do que em álcool (Nilson, 1970). No caso de beterrabas minimamente processadas, os processos de sanitização e enxagüe favorecem uma maior perda destes pigmentos devido o contato da superfície das raízes com a água.

Não foi detectada a presença de Salmonella em nenhum dos tratamentos analisados durante o armazenamento (Tabela 1). Tais resultados colocam as amostras analisadas em acordo com a Resolução RDC № 12 de 02 de janeiro de 2001, da Agência Nacional de Vigilância Sanitária (ANVISA) do Ministério da Saúde, que estabelece para hortaliças in natura ,a ausência de Samonella (em $25 \mathrm{~g}$ de produto) visando a preservação da saúde pública.

Tabela 1. Detecção de Salmonella em $25 \mathrm{~g}$ de beterrabas minimamente processadas submetidas a diferentes momentos de sanitização e armazenadas a $5 \pm 1^{\circ} \mathrm{C}$ e $85 \pm 5 \%$ UR, utilizando-se o kit "1-2 test" da Bio Control/USA.

Tratamentos
Dias após o corte

0 Ausência

Ausência

Ausência

Ausência

Antes da pelagem e após o corte

Ausência

Ausência

Após a pelagem

Ausência

Ausência

Antes e após a pelagem

Ausência

Ausência

Antes e após a pelagem, e após

Ausência

Ausência

o corte 
A contagem de coliformes totais no dia do processamento foi maior para beterrabas controle, atingindo valores $>110 \mathrm{NMP} / \mathrm{g}$ de produto (Tabela 2) em ambos os dias de análise. Para os tratamentos em que pelo um dos momentos de sanitização ocorreu após o corte das raízes, a contagem inicial de coliformes totais foi $0,91 \mathrm{NMP} / \mathrm{g}$ de produto. Foi verificado no $6^{\circ}$ dia de armazenamento, quando todos os tratamentos atingiram nota limite de comercialização, que as beterrabas dos tratamentos que sofreram a operação de sanitização apresentaram contagens de coliformes totais na ordem de $46 \mathrm{NMP} / \mathrm{g}$ de produto (Tabela 2).

Tabela 2. NMP de coliformes totais de beterrabas minimamente processadas submetidas a diferentes momentos de sanitização e armazenadas a $5 \pm 1^{\circ} \mathrm{C}$ e $85 \pm 5 \%$ UR, utilizando-se a metodologia de tubos múltiplos.

Tratamentos

Dias após o corte

0

6

Controle

$>110$

$>110$

Padrão

0,91

46

Antes da pelagem e após o corte

0,91

46

Após a pelagem

2,8

46

Antes e após a pelagem

1,5

46

Antes e após a pelagem, e após

0.91

46

o corte

Os resultados obtidos representam o NMP de coliformes totais/g de produto.

Em nenhuma das amostras de beterrabas que foram submetidas a, pelo menos, uma etapa de sanitização houve detecção de coliformes fecais (Tabela 
3). Na metodologia de tubos múltiplos, quando aparece o resultado $<0,3 \mathrm{NMP} / g$ significa que nenhum dos tubos inoculados se mostrou positivo.

Para produtos minimamente processados, ainda não existe uma legislação determinando os limites de contagens permitidas. Entretanto, estes resultados estão de acordo com a resolução RDC №12 de 02 de janeiro de 2001 da Agência Nacional de Vigilância Sanitária do Ministério da Saúde, que estabelece como padrão o máximo de $10^{2}$ NMP de coliformes fecais/g de hortaliça fresca.

Tabela 3. NMP de coliformes fecais de beterrabas minimamente processadas submetidas a diferentes momentos de sanitização e armazenadas a $5 \pm 1^{\circ} \mathrm{C}$ e $85 \pm 5 \%$ UR, utilizando-se a metodologia de tubos múltiplos.

Tratamentos

Dias após o corte

0

6

Controle

0,36

0,91

Padrão

$<0,3$

$<0,3$

Antes da pelagem e após o corte

$<0,3$

$<0,3$

Após a pelagem

$<0,3$

$<0,3$

Antes e após a pelagem

$<0,3$

$<0,3$

Antes e após a pelagem, e após

$<0,3$

$<0,3$

o corte

Os resultados obtidos representam o NMP de coliformes fecais/g de produto.

A contagem total das bactérias psicrotróficas aumentou com o decorrer dos dias de armazenamento para todos os tratamentos (Tabela 4). As beterrabas controle apresentaram as maiores contagens de bactérias psicrotróficas em ambos os dias de análise. Para os tratamentos onde pelo 
menos uma etapa de sanitização ocorreu após o corte, verificou-se que as contagens para bactérias psicrotróficas foram as menores obtidas. $\mathrm{O}$ aumento na população de bactérias psicrotróficas também foi verificado em repolhos minimamente processados, de $10^{2}$ para $10^{5} \mathrm{UFC} / \mathrm{g}$ nas amostras mantidas a $4^{\circ} \mathrm{C}$, após o quarto dia de armazenamento (Piagentini et al., 1997).

Tabela 4. Contagem total de bactérias psicrotróficas de beterrabas minimamente processadas submetidas a diferentes momentos de sanitização e armazenadas a $5 \pm 1^{\circ} \mathrm{C}$ e $85 \pm 5 \%$ UR, segundo a metodologia convencional (PCA).

\section{Tratamentos}

\section{Dias após o corte}

0

6

Controle

$1,59 \times 10^{3}$

$3,80 \times 10^{5}$

Padrão

$2,30 \times 10^{2}$

$2,36 \times 10^{4}$

Antes da pelagem e após o corte

$2,65 \times 10^{2}$

$2,26 \times 10^{4}$

Após a pelagem

$4,14 \times 10^{2}$

$6,70 \times 10^{4}$

Antes e após a pelagem

$4,42 \times 10^{2}$

$6,24 \times 10^{4}$

Antes e após a pelagem, e após

$2,01 \times 10^{2}$

$2,14 \times 10^{4}$

o corte

Os resultados obtidos representam a quantidade de UFC(unidades formadoras de colônias)/g de produto.

Embora não existam, na legislação brasileira vigente padrões, para bactérias psicrotróficas totais e coliformes totais, no que diz respeito à quantidade de microrganismos presentes em um alimento, pode-se afirmar que quantidades elevadas (> $10^{5} \mathrm{UFC} / \mathrm{g}$ ) são completamente indesejáveis, pelo menos pelas seguintes razões: risco do alimento estar estragado, perda real ou potencial das qualidades organolépticas, comprometimento da aparência do 
alimento; quanto maior o número de microrganismos em um alimento, maiores são as possibilidades da presença de patogênicos e/ou deterioradores (Caruso \& Camargo, 1984). No presente trabalho, somente as amostras de beterrabas controle com 6 dias de armazenamento, apresentavam-se com valores nessa referida ordem.

A implantação de um sistema efetivo de controle, por meio do programa de Análise de Perigo e Pontos Críticos de Controle (APPCC) é fundamental para o conhecimento e prevenção da contaminação e do crescimento microbiano em produtos minimamente processados (Vanetti, 2000).

Como se observou pelos resultados obtidos, ocorreu uma redução gradativa na coloração das raízes durante o armazenamento para todos os tratamentos. A redução na intensidade da coloração aparentemente se deve a alteração nos teores de pigmentos, já que estes foram perdidos também gradativamente com o decorrer dos dias de armazenamento. Foi verificado o aparecimento de desidratação e esbranquiçamento nas raízes minimamente processadas de todos os tratamentos durante o experimento, o que reduziu a intensidade da cor vermelha na superfície do corte. Os tratamentos onde pelo menos uma etapa de sanitização ocorreu após o corte apresentaram-se com coloração vermelho menos intenso do que os demais.

Os resultados obtidos nas análises microbiológicas de todos os tratamentos estão dentro do padrão aceitável pela legislação brasileira em vigor para hortaliças frescas. O tratamento controle, embora tenha apresentado bons resultados, não é recomendado, pois a etapa de sanitzação é essencial e indispensável para produtos minimamente processados como forma de reduzir a contaminação microbiana. Portanto, conclui-se que o momento ideal indicado para sanitizar beterrabas minimamente processadas é o após a pelagem, onde a perda de cor e pigmentos é menor em relação ao controle e as contagens microbiológicas obtidas estão dentro do padrão vigente. Mesmo este tratamento não tendo diferido significativamente do tratamento com sanitização antes e após a pelagem, ele apresenta a vantagem de economia de cloro, pois somente 
um momento de sanitização é suficiente para obter-se um produto com qualidade sensorial e segurança alimentar em até 6 dias de armazenamento.

\subsection{Conclusão}

Sob as condições experimentais estudadas, pode-se concluir que:

$\checkmark \mathrm{O}$ melhor momento para sanitizar é 0 apenas após a pelagem, onde as perdas de pigmentos e de cor são menores em relação ao tratamento controle e os padrões microbiológicos obtidos enquadram-se na legislação atual, além da economia de cloro ativo. 


\section{MÉTODOS COMBINADOS DO PROCESSAMENTO MÍNIMO DE BETERRABA}

\section{Resumo}

Raízes de beterrabas, cv. Early Wonder, foram minimamente processadas através de um fluxograma obtido a partir de testes anteriores. As etapas de processamento mínimo do produto constaram de: seleção, prélavagem, descascamento, sanitização e imersão em ácido cítrico, corte, enxague, centrifugação, embalamento e armazenamento. Realizaram-se análises físico-químicas, sensoriais e microbiológicas durante 0 armazenamento a $50 \mathrm{C}$ e $85-90 \%$ de umidade relativa. A taxa respiratória observada foi baixa. Não foi detectada presença de coliformes fecais e Salmonella. Houve uma estabilização nos teores dos pigmentos durante a conservação. De acordo com as características sensoriais, as beterrabas minimamente processadas pelo novo fluxograma tiveram um período de comercialização viável até 10 dias. O novo fluxograma desenvolvido é mais apropriado para manutenção da qualidade por reduzir perda de pigmentos, reduzir a taxa respiratória e garantir a segurança alimentar do produto.

Palavras-chave: Beta vulgaris L., pigmentos, respiração, etileno, microbiologia. 


\section{COMBINED METHODS FOR MINIMAL PROCESSING OF BEET ROOTS}

\section{Summary}

Early Wonder beet roots were minimally processed through a procedures flowchart derived from previous experiments results. The minimal processing treatment phases were: selection, pre-washing, peeling, sanitization and immersion in citric acid, cutting, rinsing, centrifugation, packing and storage. Physicochemical, sensory and microbiological analyses were conducted during storage at $5 \circ \mathrm{C}$ and $85-90 \% \mathrm{RH}$. Low respiratory rates were observed, and fecal coliforms and Salmonella were not detected. Pigment amounts stabilized during storage. Regarding sensory characteristics, beet roots minimally processed through the new procedures flowchart remained suitable for commercialization for 10 days. The new flowchart is more suitable for quality maintenance, as it reduces pigment loss and respiratory rate, while it ensures good food safety standards.

Key-words: Beta vulgaris L., pigments, respiration, ethylene, microbiology.

\subsection{Introdução}

Os consumidores estão cada vez mais conscientes da importância dos alimentos frescos para a saúde humana (Wiley, 1994). Por este motivo, a utilização de produtos hortícolas minimamente processados está aumentando bastante, sobretudo em razão do interesse que os produtos naturais e convenientes tem despertado no consumidor ( Durigan \& Sargent, 1999).

A fisiologia de um tecido vegetal minimamente processado é semelhante aquela observada em tecidos de plantas que sofreram ferimentos ou foram expostas a condições de estresse. Esta fisiologia inclui aumento na respiração 
e na produção de etileno. Outras consequências do ferimento são de natureza química ou física, tais como reações de escurecimento enzimático e oxidação de lipídeos, ou aumento na perda de água (Brecht, 1995).

A conservação de um produto está diretamente relacionada com a taxa respiratória, sendo que esta é diretamente proporcional à perecibilidade. Os produtos minimamente processados são mais perecíveis que tecidos intactos. Portanto, tratamentos que reduzam a respiração são importantes para minimizar conseqüências negativas e promover 0 aumento da vida de prateleira.

Adicionalmente, o processamento mínimo favorece a contaminação por microrganismos deterioradores e patogênicos, em razão do manuseio excessivo e do aumento das injúrias nos tecidos, que podem diminuir a qualidade e o tempo de vida útil do produto por acelerarem mudanças degradativas durante a senescência (Wiley, 1994).

Dentre as hortaliças minimamente processadas no Brasil, a beterraba está aumentando em sua importância. É uma raiz tuberosa de cor vermelhoarroxeada devido à presença de betalaínas. As betalaínas são pigmentos hidrossolúveis e são divididos em duas classes: betacianina (cor avermelhada) e betaxantina (cor amarelada), caracterizando a coloração típica das raízes. Estes pigmentos, além de fornecerem cor à beterraba, são importantes substâncias antioxidantes para a dieta humana (Kanner et al., 2001).

Um dos principais problemas tecnológicos observado em beterraba minimamente processada é a descoloração significativa e desidratação do material minimamente processado. As operações de lavagem, sanitização e enxague realizadas após o corte favorecem a perda de betacianina e betaxantina. Devido àestes pigmentos serem solúveis em água (Nilson, 1970).

Durante o processo de preparo dos produtos minimamente processados, as etapas de sanitização e enxague são essenciais, como forma de minimizar a deterioração e manter a qualidade do produto (Brackett, 1992; Hurst, 1995), sendo a lavagem com água clorada recomendada (Madden, 1992). 
Com o objetivo de ampliar o conhecimento, atender as novas demandas do mercado e aumentar as alternativas tecnológicas, este trabalho se propôs a estudar o fluxograma de preparo específico desenvolvido a partir de testes experimentais anteriores e verificar seu efeito na qualidade de beterrabas minimamente processadas.

\subsection{Material e Métodos}

\section{Obtenção do material experimental}

As beterrabas, cv. Early Wonder, colhidas na região de Piracicaba-SP, foram levadas para o Laboratório de Pós-Colheita do Departamento de Produção Vegetal da ESALQ/USP onde foram selecionadas quanto ao tamanho, firmeza, cor e formato, tendo sido descartadas raízes murchas, e com defeitos e injúrias. Estas foram pré-lavadas em água corrente com o objetivo de retirar as impurezas advindas do campo. A seguir, o material experimental foi minimamente processado.

\section{Processamento mínimo}

As etapas de processamento mínimo ocorreram dentro da câmara fria $\left(10 \pm 1^{\circ} \mathrm{C}\right)$ sobre mesa de aço inoxidável devidamente higienizada. Os operadores utilizaram roupas protetoras (botas, aventais, luvas, máscaras e toucas), como parte das condições mínimas de assepsia.

As etapas de processamento constaram de:

a) Descascamento: $O$ produto foi descascado mecanicamente por descascadora industrial (Shymsen) com disco abrasivo para retirada da película externa das raízes.

b) Sanitização e imersão em ácido cítrico: o material foi sanitizado via imersão por 3 minutos em água clorada (200ppm de cloro ativo), com o objetivo de reduzir riscos de contaminação. A água também continha $2000 \mathrm{mg} \mathrm{L}^{-1}$ de ácido cítrico, com o objetivo de reduzir a taxa respiratória e a evitar o extravazamento 
de pigmentos na água de sanitização. O sanitizante utilizado foi o SUMAVEG. Este produto tem como principio ativo o Dicloro-S-Triazinatriona Sódica Diidratada e é fabricado pela Diversey Lever-Indústrias Gessy Lever Ltda.

c) Corte: as beterrabas foram submetidas a etapa de corte em forma de retalhos. Utilizou-se uma processadora industrial (Robot Coupe) com disco de espessura de $2 \mathrm{~mm}$.

d) Enxague: as raízes foram enxaguadas através de imersão por 1 minuto (em água com 3ppm de cloro ativo) para a retirada do excesso de cloro. O mesmo sanitizante foi utilizado.

e) Centrifugação: realizada em centrífuga doméstica (ARNO) durante 1 minuto para a retirada do excesso de umidade do produto, com velocidade de 2000rpm.

f) Armazenamento: as raízes foram armazenadas a $5 \pm 1^{\circ} \mathrm{C}$ e $85 \pm 5 \%$ UR durante 10 dias, em bandejas de poliestireno expandido, com dimensões $14 \times 20 \mathrm{~cm}$ de largura e comprimento, respectivamente, envoltas com filmes de PVC (policloreto de vinila) com $14 \mu \mathrm{m}$ de espessura.

\section{Determinações}

As avaliações foram realizadas a cada 2 dias, durante 10 dias de armazenamento para as análises fisiológicas e físico-químicas. As análises microbiológicas foram realizadas no dia do processamento e no $10^{\circ}$ dia de armazenamento.

\section{Taxa respiratória}

As raízes foram acondicionadas em jarros de vidro $(600 \mathrm{~mL})$ hermeticamente fechados durante 1 hora e armazenadas a temperatura de $5^{\circ} \mathrm{C}$. $\mathrm{Na}$ tampa dos frascos foi colocado um septo de silicone através do qual foi retirada uma alíquota da atmosfera interna dos frascos $(2 \mathrm{~mL})$ e medido o conteúdo de $\mathrm{CO}_{2}$ em um analisador de gases PBI Dansensor 9900. Os resultados expressos em \% $\mathrm{CO}_{2}$ foram utilizados para cálculo da taxa 
respiratória levando-se em consideração o volume do frasco, a massa das beterrabas e o tempo em que o frasco permaneceu fechado. Os resultados foram expressos em $\mathrm{mL} \mathrm{CO}_{2} \mathrm{~kg}^{-1} \mathrm{~h}^{-1}$.

\section{Produção de etileno}

O procedimento para determinação da taxa de produção de etileno foi semelhante ao utilizado para determinação da taxa respiratória. A taxa de síntese de etileno foi obtida retirando-se com auxílio de uma seringa uma alíquota de $0,5 \mathrm{~mL}$ de amostra da composição gasosa do interior dos jarros e injetada em cromatógrafo a gás (Shimadzu GC 14-B) com detector de ionização de chama, utilizando-se uma coluna "HayeSep T". O gás de arraste foi o nitrogênio, a um fluxo de $20 \mathrm{~mL}$ minuto ${ }^{-1}$. As temperaturas mantidas no aparelho foram de $80^{\circ} \mathrm{C}$ para a coluna, $100^{\circ} \mathrm{C}$ no injetor e $150^{\circ} \mathrm{C}$ no detector. Como padrão foi utilizado etileno puro $\left(1 \mu \mathrm{L} \mathrm{C}_{2} \mathrm{H}_{4} \mathrm{~kg}^{-1} \mathrm{~h}^{-1}\right)$, da White Martins. Os resultados foram expressos em $\mu \mathrm{L} \mathrm{C}_{2} \mathrm{H}_{4} \mathrm{~kg}^{-1} \mathrm{~h}^{-1}$.

\section{Teor de Sólidos Solúveis Totais}

O teor de sólidos solúveis totais foi realizado por leitura direta em refratômetro digital (Atago), utilizando-se uma gota de raiz centrifugada em

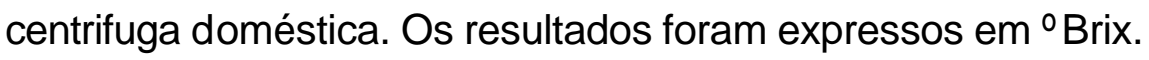

$\underline{\text { Cor }}$

Foi determinada por colorímetro (Minolta), obtendo-se os valores de $L a^{*}$ $b^{*}$ e calculando-se o índice de cor (IC) através da fórmula $I C=1000 \times a^{*} / L \times b^{*}$ (Mazzuz, 1996). Segundo o autor o IC varia de -20 a +20 sendo que quanto mais positivo mais intenso é o vermelho As leituras foram realizadas diretamente sobre o produto minimamente processado. 
Teor de Betacianina e Betaxantina

A metodologia utilizada foi adaptada de Nilson (1970), onde $2 \mathrm{~g}$ de amostra previamente congeladas foram maceradas em $5 \mathrm{~mL}$ de água destilada. A solução foi colocada em tubetes e centrifugada utilizando-se centrífuga refrigerada (Sorvall) a $4^{\circ} \mathrm{C}$ (15000rpm) durante 40 minutos. Num tubo de ensaio foram homogenizados $1 \mathrm{~mL}$ do sobrenadante e $24 \mathrm{~mL}$ de água destilada. Foram feitas leituras das amostras a $476 \mathrm{~nm}, 538 \mathrm{~nm}$ e $600 \mathrm{~nm}$. Os cálculos foram feitos através das seguintes fórmulas: $x=1,095(a-c), y=b-z-x / 3,1$ e $z=a-x$, sendo: $a=$ leitura da amostra (538nm); b= leitura da amostra $(476 \mathrm{~nm}) ; c=$ leitura da amostra $(600 \mathrm{~nm})$; $x=$ absorção de betacianina; $y=$ absorção de betaxantina; $z=$ absorção de impurezas.

Avaliação Sensorial (aparência global):

Foi realizada por uma equipe de 10 analisadores treinados utilizando-se uma escala de notas adaptada de Peryam \& Girarddot (1952), onde: 9= excelente; $7=$ bom; $5=$ regular; $3=$ ruim; $1=$ péssimo. A descrição das notas foram: 9 = beterraba com aspecto de frescor e ausência de esbranquiçamento; $7=$ beterraba com aspecto de frescor, porém com leve esbranquiçamento; $5=$ beterraba com pouco aspecto de frescor e moderado esbranquiçamento; $3=$ beterraba sem aspecto de frescor, elevado esbranquiçamento; 1=beterraba totalmente desidratada e esbranquiçada. A nota 5 foi considerada como limite de comercialização (vide ANEXO B).

\section{Análises microbiológicas}

A microbiota contaminante da beterraba minimamente processada foi avaliada pela contagem total de bactérias psicrotróficas, número mais provável (NMP) de coliformes totais e fecais e presença/ausência de Salmonella.

As análises para contagem de bactérias psicrotróficas e para o NMP de coliformes foram efetuadas em porções de $20 \mathrm{~g}$ de raízes para cada repetição, pesadas assepticamente e colocadas em erlenmeyers, com $180 \mathrm{~mL}$ de água 
peptonada $(0,1 \%)$ estéril, constituindo a diluição $10^{-1}$. A partir da diluição $10^{-1}$, obteve-se a diluição $10^{-2}$, pipetando-se $10 \mathrm{~mL}$ da solução $10^{-1} \mathrm{em} 90 \mathrm{~mL}$ de água peptonada esterilizada $(0,1 \%) \mathrm{e}$, a partir desta, obteve-se a diluição $10^{-3} \mathrm{e}$ assim sucessivamente.

A determinação da presença de Salmonella foi a única análise que dispensou o uso de diluições, por ter sido empregada uma metodologia distinta (descrita posteriormente).

a) Contagem total de bactérias psicrotróficas

Para contagem de bactérias psicrotróficas (qualquer bactéria cujo ótimo de temperatura para crescimento situa-se acima de $20^{\circ} \mathrm{C}$, porém toleram e crescem sob refrigeração), utilizou-se o meio Ágar Padrão para Contagem (PCA).

O princípio desta metodologia baseia-se na capacidade que cada célula microbiana presente na amostragem, tem de formar uma colônia visível e isolada, uma vez fixada em um meio de cultura sólido próprio para seu desenvolvimento (Silva et al., 2001).

A partir da diluição $10^{-1}$ até a $10^{-4}$ das beterrabas minimamente processadas, foram plaqueados em profundidade, $1 \mathrm{~mL}$ de cada diluição em duplicata, utilizando-se $20 \mathrm{~mL}$ de meio de cultivo PCA. Após o plaqueamento, as placas permaneceram em repouso até completa solidificação do meio, sendo, então invertidas e incubadas a $7^{\circ} \mathrm{C}$ por 10 dias (vide ANEXO C).

Decorrido o tempo de incubação foram selecionadas as placas e fez-se a contagem das mesmas, com auxílio do contador de colônias tipo Quebec.

b) NMP de coliformes totais e fecais

Coliformes totais e fecais foram determinados pelo método do NMP, através da técnica dos Tubos Múltiplos (vide ANEXO D).

A técnica de Tubos Múltiplos conta de duas fases distintas: a fase do teste presuntivo, onde se busca detectar a presença de microrganismos 
fermentadores de lactose e onde é possível recuperar células injuriadas e a fase do teste confirmativo, através do qual se determina a população real de coliformes totais e fecais.

Para o teste presuntivo foram utilizadas séries de três tubos de ensaio, os quais continham um tubo de Durham e Caldo Lactosado (CL), um meio cuja fonte de carbono é a lactose que é fermentada pelas bactérias do grupo coliforme, com produção de ácido e gás.

A primeira série contou com tubos em dupla concentração do meio, uma vez que, nessa série, foram adicionados $10 \mathrm{~mL}$ do inóculo, da diluição $10^{-1}$, evitando-se assim, uma diluição excessiva do caldo (meio de cultivo). As demais séries continham CL em concentração normal, sendo que em cada tubo da segunda série, adicionou-se $1 \mathrm{~mL}$ da diluição $10^{-1} \mathrm{e}$, em cada tubo da terceira série, adicionou-se $1 \mathrm{~mL}$ da diluição $10^{-2}$.

Todos os tubos foram ncubados em estufa termostatizada a $35-37^{\circ} \mathrm{C}$, por 24-48h. Após 24 e 48 horas de incubação, sendo positivos os resultados, foi possível observar o esvaziamento dos tubos de Durham, devido à produção de gás pelas bactérias do grupo coliforme ao fermentarem a lactose.

Alíquotas dos tubos positivos do teste presuntivo foram transferidas para o teste confirmativo, verificando-se, assim, se realmente, tratavam-se de bactérias do grupo coliforme.

Utilizando-se a alça de níquel-cromo, foram inoculados tubos de Caldo Verde Brilhante Lactose Bile (CVBLB), em concentração simples, e tubos de Caldo EC, correspondentes aos tubos positivos da fase anterior.

Os tubos de CVBLB foram incubados em estufa termostatizada à temperatura de $35-37^{\circ} \mathrm{C}$ durante $24-48 \mathrm{~h}$, sendo verificada, após esse período a formação ou não de gás nos tubos de Durham. A formação de gás em CVBLB, confirma a presença de bactérias do grupo coliforme, podendo ser de origem fecal ou não, denominadas coliformes totais. 
Os tubos de EC, uma vez inoculados, foram incubados em banho-maria termostatizado àtemperatura de $45^{\circ} \mathrm{C}$ por 24 horas. A formação de gás em EC, confirma a presença de coliformes fecais após esse período de incubação.

A partir do número de tubos positivos em cada série de ambos os meios, consultando-se seus valores correspondentes na tabela da Associação Brasileira de Normas Técnicas MB 3463 (vide ANEXO E), obteve-se o NMP de coliformes totais (CVBLB) e fecais (Caldo EC), por g de beterraba ralada.

\section{c) Detecção de Salmonella}

Para detecção de Salmonella, utilizou-se o Kit '1-2 test', fabricado pela BioControl/USA. Trata-se de um método oficial aprovado pela AOAC (Association of Official Analytical Chemists Internacional) para utilização em todos os tipos de alimentos.

Foi feito um pré-enriquecimento de cada amostra analisada, inoculandose $25 \mathrm{~g}$ de beterraba ralada em um erlenmeyer contendo $225 \mathrm{~mL}$ de água peptonada tamponada esterilizada. Os frascos foram incubados em estufa termostatizada, a $35^{\circ} \mathrm{C}$ por 24 horas. O pré-enriquecimento é possível pela exigência de ausência de Salmonella em $25 \mathrm{~g}$ de qualquer alimento analisado para consumo humano. Deste modo se a bactéria estiver presente no alimento, não importando o número de bactérias presentes, o alimento é considerado impróprio para o consumo humano. Com o pré-enriquecimento, sua multiplicação é favorecida, facilitando a detecção na análise, uma vez que tal patógeno encontra-se normalmente em níveis baixos nos alimentos. Decorrido o período de incubação fez-se o preparo dos kits, compostos, cada um, de dois compartimentos. A amostra pré-enriquecida foi inoculada na câmara de inoculação $(0,1 \mathrm{~mL})$ onde primariamente foi adicionada uma gota de solução de iodo-iodeto e depois removido o tampão desta câmara com auxílio de uma

pinça estéril. A câmara de motilidade contém um meio de motilidade não seletivo, a base de peptona. Esta câmara é fechada por uma pequena ponteira (que foi retirada) para formar um vão no gel, e adicionou-se uma gota da 
solução de anticorpos polivalentes anti-Salmonella. Incubou-se os kits a $35^{\circ} \mathrm{C}$ por 24 horas. Após a incubação foi feita a leitura dos resultados.

A possível presença de Salmonella é caracterizada pela formação de uma imunobanda na metade superior do gel na câmara de motilidade. Trata-se de uma banda branca que apresenta forma de $U$ formada pela aglutinação das células da bactéria com a solução de anticorpos.

\section{Análise dos resultados}

O delineamento experimental empregado foi inteiramente casualizado com 5 repetições. Cada repetição foi composta de aproximadamente $180 \mathrm{~g}$ de beterraba. Os resultados das análises fisiológicas e físico-químicas foram submetidos à análise do desvio padrão. Para avaliação dos aspectos microbiológicos os resultados foram expressos em UFC/g de produto para bactérias psicrotróficas, NMP/g para coliformes totais e fecais e presença ou ausência de Salmonella em $25 \mathrm{~g}$ de produto.

\subsection{Resultados e Discussão}

A atividade respiratória de beterrabas minimamente processadas foi baixa, sendo que a partir do 20 dia de armazenamento verificou-se uma estabilização em valores próximos a $3,6 \mathrm{~mL} \mathrm{CO}_{2} \mathrm{~kg}^{-1} \mathrm{~h}^{-1}$ (Figura 1a).

O tratamento com ácido cítrico pode ter servido como sinalizador para um abaixamento da atividade respiratória ou ainda, estar envolvido na inibição da enzima fosfofrutoquinase, que catalisa a fosforilação da frutose 6-fosfato em frutose 1,6- bisfosfato na via glicolítica do metabolismo respiratório (Turner \& Turner, 1980). Kato-Noguchi \& Watada (1997) observaram que a taxa respiratória de cenouras minimamente processadas foi substancialmente reduzida com a aplicação de ácido cítrico. 

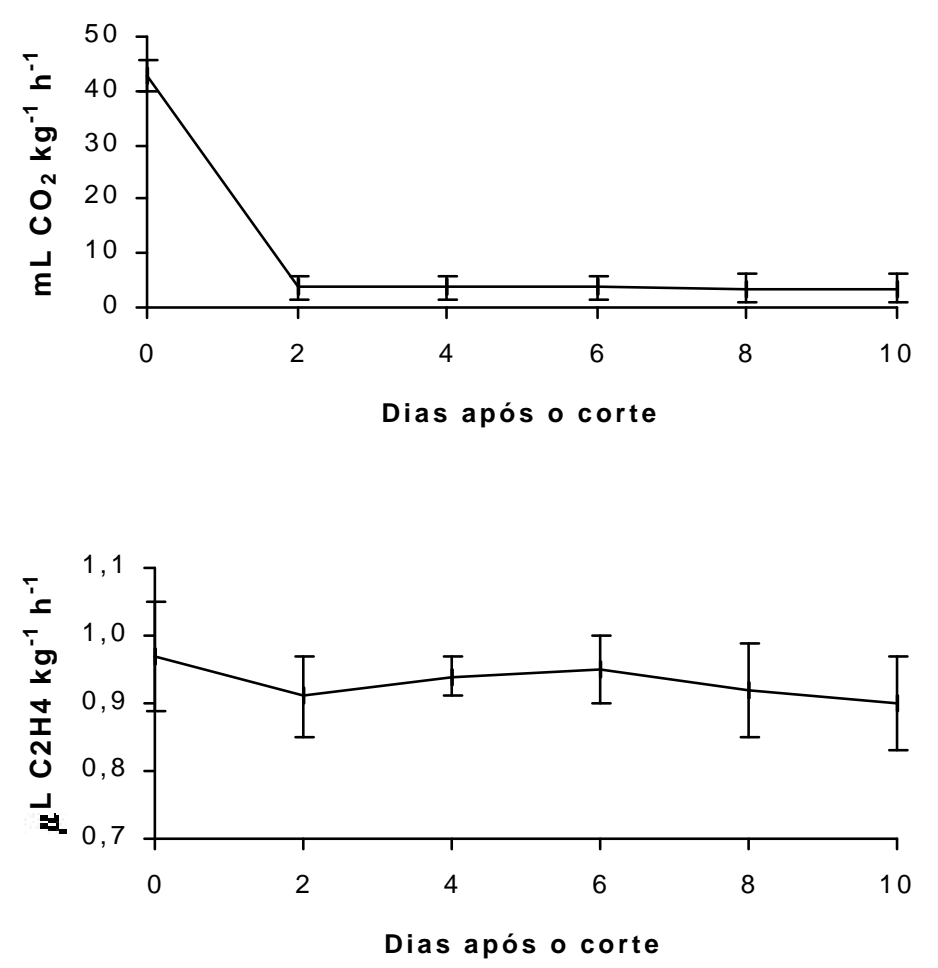

Figura 1 - Taxa respiratória (a) e produção de etileno (b) de beterrabas minimamente processadas a armazenadas a $5 \pm 1^{\circ} \mathrm{C}$ e $85 \pm 5 \%$ UR. Barras verticais indicam o desvio padrão da média.

A produção de etileno logo após o corte atingiu valores próximos a $0,95 \mu \mathrm{L}_{2} \mathrm{H}_{4} \mathrm{~kg}^{-1} \mathrm{~h}^{-1}$, havendo pouca variação ao longo do período de conservação (Figura 1b).

Os produtos minimamente processados são mais perecíveis do que quando intactos, considerando que são submetidos a severos estresses físicos, advindos, principalmente, do descascamento e do corte. Esses danos mecânicos aumentam o metabolismo, com consequente aumento da síntese de etileno, causando maior velocidade de deterioração. O etileno proveniente do corte ("etileno de ferida") contribui para a biossíntese de enzimas envolvidas em alterações fisiológicas e bioquímicas associadas àsenescência (Brecht, 1995). 
De acordo com Sakr et al. (1997), o aumento da produção de etileno pode ser uma resposta hormonal e bioquímica devido ao estresse causado pelo corte. Isto ocorre pois o primeiro alvo desse estresse é a membrana plasmática, a qual responde com mudanças em suas características físicas, de forma a contornar tais perturbações e tentar reparar os danos causados durante 0 processamento.

Houve uma estabilização no teor de sólidos solúveis para beterrabas minimamente processadas durante todo o armazenamento (Figura 2a).

Foi observado para os valores de IC (índice de cor), uma redução gradativa com o decorrer do período de armazenamento (Figura 2b).

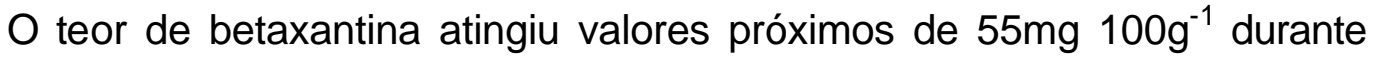
todo o armazenamento (Figura 2c).

O teor de betacianina teve comportamento semelhante ao teor de betaxantina, sendo que as beterrabas apresentaram valores ao redor de $98 \mathrm{mg}$ de betacianina $100^{-1} \mathrm{~g}$ durante todo o período de conservação (Figura 2d).

Os teores de betacianina para beterrabas intactas variam de $23,5-240 \mathrm{mg}$ $100 \mathrm{~g}^{-1}$, segundo vários autores (Nilson, 1970; Elbe et al, 1972, 1981; Sapers \& Hornstein, 1979).

Sapers \& Hornstein (1979) concluíram que ocorrem grandes diferenças no conteúdo de betacianina e betaxantina nas variedades de beterraba de mesa. Diferenças também ocorrem dentro de um cultivar, sendo alguns cultivares mais variáveis que outros. 

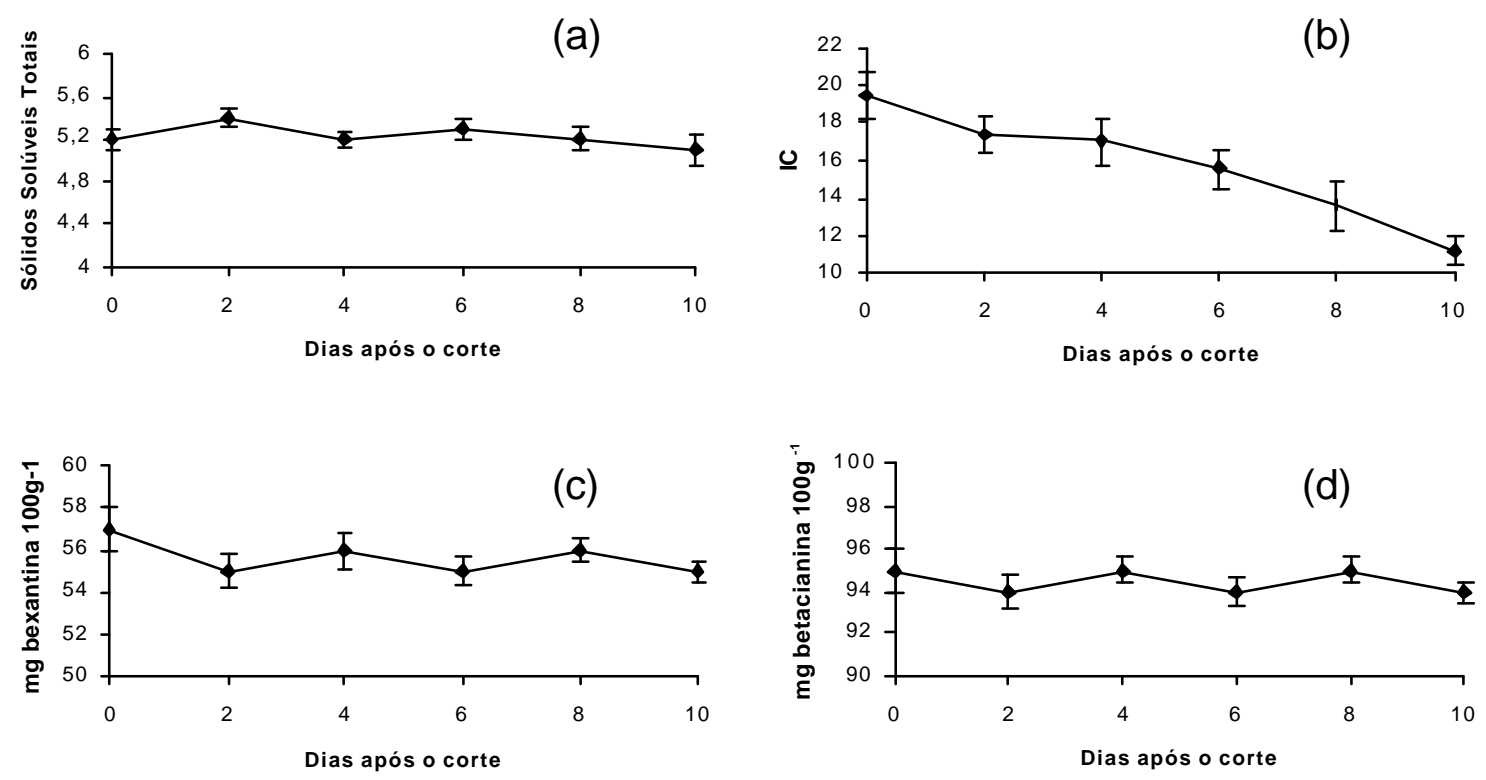

Figura 2 - Teor de sólidos solúveis totais (a), índice de cor (b), Teor de bexantina (c) e teor de betacianina em beterrabas minimamente processadas a armazenadas a $5 \pm 1^{\circ} \mathrm{C}$ e $85 \pm 5 \%$ UR. Barras verticais indicam o desvio padrão da média.

Os pigmentos de betalaínas são bastante solúveis em água (Nilson, 1970), sendo que, no caso de beterrabas minimamente processadas, os processos de sanitização e enxagüe favorecem uma maior perda destes pigmentos devido ao maior contato da superfície das raízes com a água. A imersão em ácido cítrico ou em outro tipo de antioxidante parece reduzir o extravazamento do pigmento.

Salgado (1997) observou que a adição de antioxidante, como o ácido ascórbico, melhora a estabilidade do pigmento de betalaína em beterraba, sendo que a concentração de $400 \mathrm{mg} \mathrm{L}^{-1}$ foi a melhor para preservar a cor do produto. O ácido cítrico teve semelhante efeito protetor quando comparado com o ácido ascórbico em beterrabas. Ambos os ácidos usados em combinação 
não obtiveram efeito maior do que quando utilizados isoladamente (Attoe \& Elbe, 1985).

Até $02^{\circ}$ dia de armazenamento (Figura 3) as beterrabas apresentaram aparência excelente, ou seja, beterraba com aspecto de frescor e ausência de esbranquiçamento. No $10^{\circ}$ dia de armazenamento as raízes atingiram nota 5 , ou seja, nota limite de comercialização. O tempo de vida útil para beterrabas minimamente processadas preparadas pelo fluxograma específico foi de 10 dias.

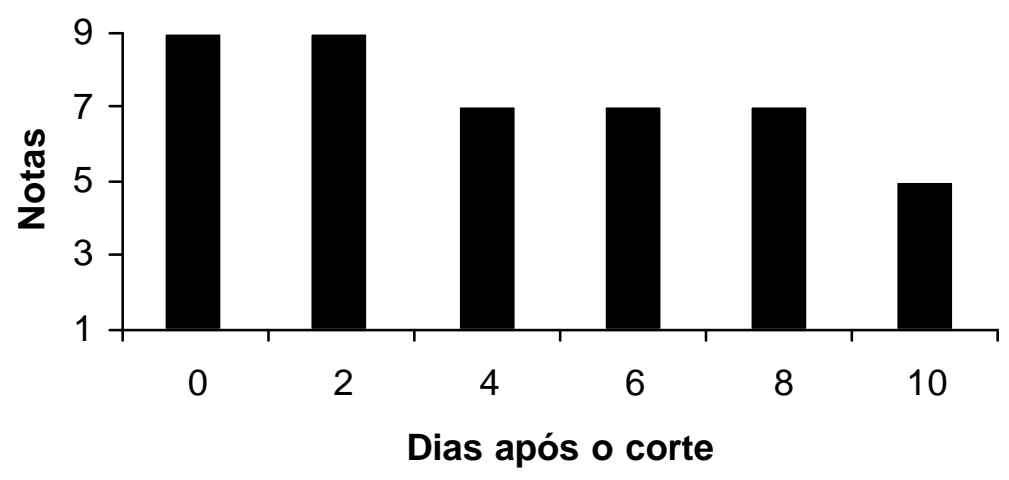

Figura 3 - Análise sensorial de beterrabas minimamente processadas e armazenadas a $5 \pm 1^{\circ} \mathrm{C}$ e $85 \pm 5 \%$ UR. (Notas: 9=excelente; $7=$ bom; $5=$ regular; $3=$ ruim; $1=$ péssimo).

O tecido esbranquiçado que se forma na superfície, semelhante ao que ocorre em cenoura minimamente processada (denominada "white blush"), torna o produto com aparência envelhecida e não atraente. Enquanto para alguns pesquisadores o esbranquiçamento é resultado da desidratação das células superficiais danificadas pelo pré-processamento (Avena-Bustillos et al., 1994; Tatsumi et al., 1993), para outros é devido à formação de lignina na superfície dos cortes (Bolin \& Huxsoll, 1991). Para um terceiro grupo, o esbranquiçamento é causado pela combinação dos dois processos, a desidratação e a formação de lignina (Cisneros-Zevallos et al., 1995). 
A contagem inicial das bactérias psicrotróficas foi de aproximadamente $4,48 \times 10^{2} \mathrm{UFC} / \mathrm{g}$ (Tabela 1), ao passo que, no $10^{\circ}$ dia de armazenamento as contagens obtidas aumentaram para valores próximos de $6,45 \times 10^{4} \mathrm{UFC} / \mathrm{g}$. Piagentini et al. (1997) relataram aumento na população de microrganismos psicrotróficos em repolho minimamente processado, de $10^{2}$ para $10^{5} \mathrm{UFC} / \mathrm{g}$ após quatro dias de armazenamento do produto a $4^{\circ} \mathrm{C}$. García-Gimeno \& Zurera-Cosano (1997) observaram aumento de $10^{5}$ para $10^{7} \mathrm{UFC} / \mathrm{g}$ na contagem de microrganismos psicrotróficos em amostras de saladas de hortaliças minimamente processadas armazenadas a $4^{\circ} \mathrm{C}$.

Tabela 1. Contagem total de bactérias psicrotróficas, em beterrabas minimamente processadas armazenadas a $5+1^{\circ} \mathrm{C}$ e $85 \pm 5 \%$ UR, utilizando-se a metodologia convencional (PCA).

\begin{tabular}{ccc}
\hline Repetição & \multicolumn{2}{c}{ Dias após o corte } \\
& $\mathbf{0}$ & $\mathbf{1 0}$ \\
\hline 1 & $4,24 \times 10^{2}$ & $6,36 \times 10^{4}$ \\
2 & $4,89 \times 10^{2}$ & $6,18 \times 10^{4}$ \\
3 & $4,47 \times 10^{2}$ & $6,12 \times 10^{4}$ \\
4 & $4,60 \times 10^{2}$ & $6,49 \times 10^{4}$ \\
5 & $4,18 \times 10^{2}$ & $6,92 \times 10^{4}$ \\
\hline Os resultados obtidos representam a média aritmética das UFC (unidades formadoras de \\
colônias)/g de produto.
\end{tabular}

A contagem inicial de coliformes totais foi, em média, 2,1 NMP/g de produto. Foi verificado no $10^{\circ}$ dia de armazenamento, quando as repetições atingiram nota limite de comercialização, que as contagens de coliformes totais alcançaram valores em torno de $46 \mathrm{NMP} / \mathrm{g}$ de produto (Tabela 2). 
Tabela 2. NMP de coliformes totais, em beterrabas minimamente processadas armazenadas a $5+1^{\circ} \mathrm{C}$ e $85 \pm 5 \%$ UR, utilizando-se a metodologia de tubos múltiplos.

\begin{tabular}{cccc}
\hline Repetição & \multicolumn{3}{c}{ Dias após o corte } \\
& $\mathbf{0}$ & $\mathbf{1 0}$ \\
\hline 1 & 2,1 & 46 \\
2 & 2,1 & 46 \\
3 & 2,8 & 46 \\
4 & 2,1 & 46 \\
5 & 2,1 & 46 \\
\hline
\end{tabular}

Durante o armazenamento, não foi detectada a presença de coliformes fecais (Tabela 3). Na metodologia de tubos múltiplos, resultado menor que 0,3NMP/g significa que nenhum dos tubos inoculados se mostrou positivo.

Estes resultados estão de acordo com a resolução RDC №12 de 02 de janeiro de 2001 da Agência Nacional de Vigilância Sanitária do Ministério da Saúde, que estabelece como padrão o máximo de $10^{2} \mathrm{NMP}$ de coliformes fecais/g de hortaliça fresca.

Embora não existam, na legislação brasileira vigente padrões, para bactérias psicrotróficas totais e coliformes totais, no que diz respeito à quantidade de microrganismos presentes em um alimento, pode-se afirmar que quantidades elevadas (> $10^{5} \mathrm{UFC} / \mathrm{g}$ ) são completamente indesejáveis, pelo menos pelas seguintes razões: risco do alimento estar estragado, perda real ou potencial das qualidades organolépticas, comprometimento da aparência do alimento; quanto maior o número de microrganismos em um alimento, maiores são as possibilidades da presença de patogênicos e/ou deterioradores (Caruso \& Camargo, 1984). No presente ensaio, as maiores contagens microbianas estiveram em níveis de $10^{4} \mathrm{UFC} / \mathrm{g}$, ou seja, abaixo desses limites mencionados e que seriam indesejáveis àboa conservação do produto. 
Tabela 3. NMP de coliformes fecais, em beterrabas minimamente processadas armazenadas a $5 \pm 1^{\circ} \mathrm{C}$ e $85 \pm 5 \%$ UR, utilizando-se a metodologia de tubos múltiplos.

\begin{tabular}{ccc}
\hline Repetição & Dias após o corte & \\
& $\mathbf{0}$ & $\mathbf{1 0}$ \\
\hline 1 & $<0,3$ & $<0,3$ \\
2 & $<0,3$ & $<0,3$ \\
3 & $<0,3$ & $<0,3$ \\
4 & $<0,3$ & $<0,3$ \\
5 & $<0,3$ & $<0,3$ \\
\hline
\end{tabular}

Os resultados obtidos representam o NMP de coliformes fecais/g de produto.

Não foi detectada a presença de Salmonella em nenhuma das repetições analisadas durante o armazenamento (Tabela 4). Tais resultados, colocam as amostras analisadas em acordo com a Resolução RDC №12 de 02 de janeiro de 2001, da Agência Nacional de Vigilância Sanitária (ANVISA) do Ministério da Saúde, que estabelece para hortaliças in natura a ausência de Salmonella (em $25 \mathrm{~g}$ de produto) visando a preservação da saúde pública.

Tabela 4. Detecção de Salmonella em $25 \mathrm{~g}$ de beterrabas minimamente processadas e armazenadas a $5 \pm 1^{\circ} \mathrm{C}$ e $85 \pm 5 \%$ UR, utilizando-se 0 kit "1-2 test" da BioControl/USA.

\begin{tabular}{clc}
\hline & \multicolumn{2}{c}{ Dias após o corte } \\
Repetição & $\mathbf{0}$ & $\mathbf{1 0}$ \\
\hline 1 & Ausência & Ausência \\
2 & Ausência & Ausência \\
3 & Ausência & Ausência \\
4 & Ausência & Ausência \\
5 & Ausência & Ausência \\
\hline
\end{tabular}


Segundo Pilon et al. (2002), o resultado das análises microbiológicas para amostras de cenoura minimamente processadas foi negativo para coliformes fecais e Salmonella durante todo o armazenamento, sendo que somente as bactérias psicrotróficas apresentaram aumento de crescimento.

Conforme observado no presente estudo, a taxa respiratória obtida é baixa, pois ácido cítrico desempenha um papel importante de sinalizador ou de inibidor enzimático. Ocorreu uma redução gradativa na coloração das raízes durante todo o período de armazenamento. Provavelmente a redução da cor seja devido ao esbranquiçamento característico e a desidratação significativa na superfície do corte. Aparentemente esta redução não se deve a alteração nos teores de pigmentos, já que estes mantiveram-se constante com o decorrer do armazenamento, sendo a imersão em ácido cítrico de fundamental importância pois evita a degradação do pigmento, além de reduzir o extravazamento do mesmo. Os padrões microbiológicos obtidos estão de acordo com a normas estabelecidas pela ANVISA em 02/02/2001. Portanto conclui-se que o novo fluxograma desenvolvido, onde a etapa de sanitização ocorre antes do corte é viável para manutenção da qualidade sensorial e segurança alimentar de beterrabas minimamente processadas, onde a perda de pigmentos é menor e a qualidade microbiológica se enquadra na legislação vigente, além de promover um aumento na vida útil.

\subsection{Conclusão}

- Pode-se concluir que o novo fluxograma de preparo para beterrabas minimamente processadas é recomendado pois permite uma maior conservação do produto. 


\section{CONSIDERAÇÃO FINAL}

Apesar do grande potencial dos produtos minimamente processados, ainda existem muitos problemas na produção e comercialização, tais como falta de embalagens adequadas, de tecnologias para produção, de educação dos consumidores, de uma adequada cadeia de frio e legislação sanitária específica.

Existe também a necessidade de estudos que permitam estabelecer as cultivares mais indicadas, o tipo de preparo e a temperatura de armazenamento que presevem a vida útil do produto por um período maior.

Diante de tantos desafios, este trabalho permitiu expor a possibilidade de se obter beterrabas minimamente processadas, com boa qualidade, além de se estabelecer alguns parâmetros através das respostas fisiológicas, bioquímicas e microbiológicas encontradas neste produto.

Alguns problemas, como perda de pigmentos e aumento da taxa respiratória podem ser minimizados através da utilização do fluxograma de preparo específico para beterrabas minimamente processadas desenvolvido a partir de vários testes. 
ANEXOS 
ANEXO A - Sequência do Processamento Mínimo de Beterraba.
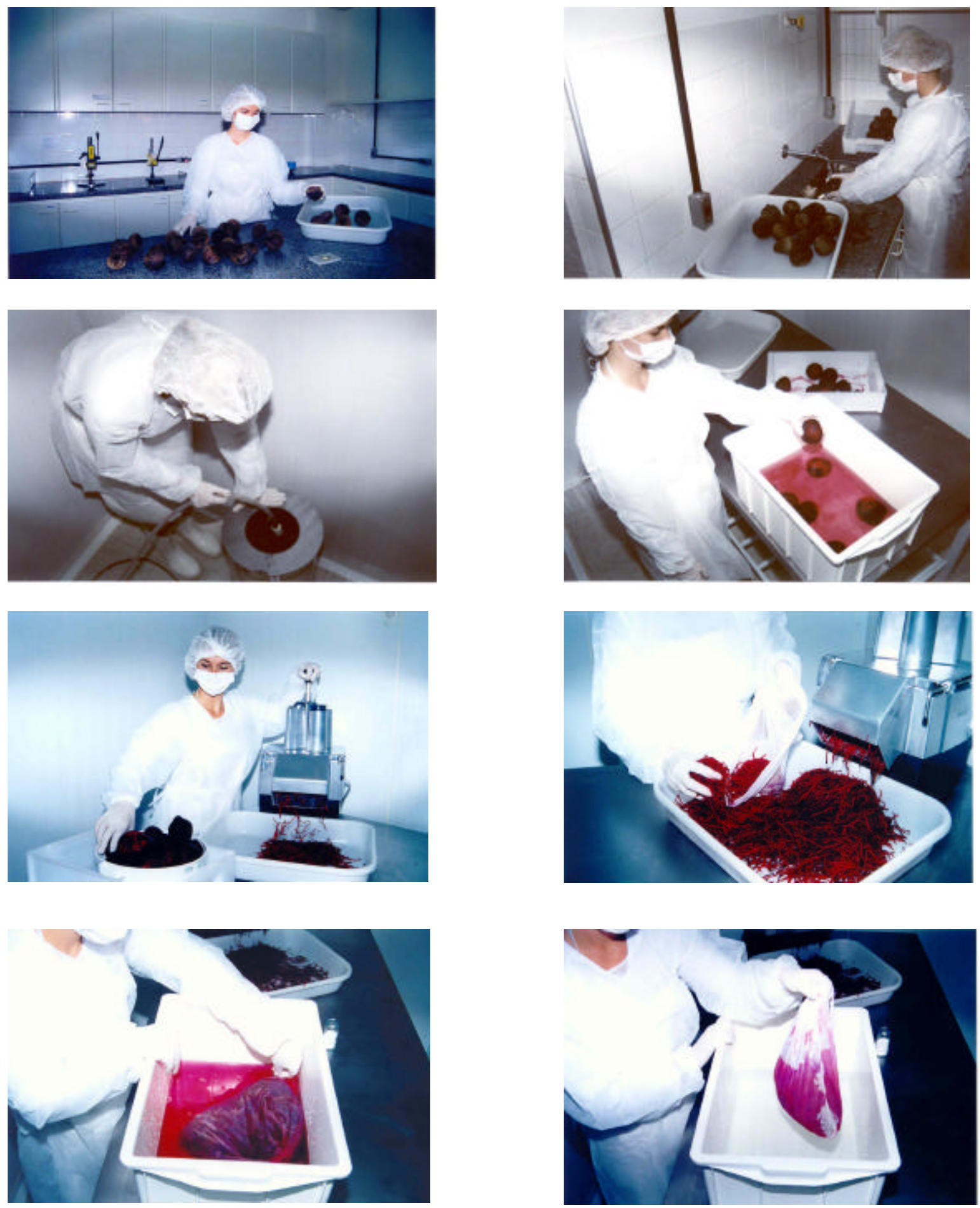

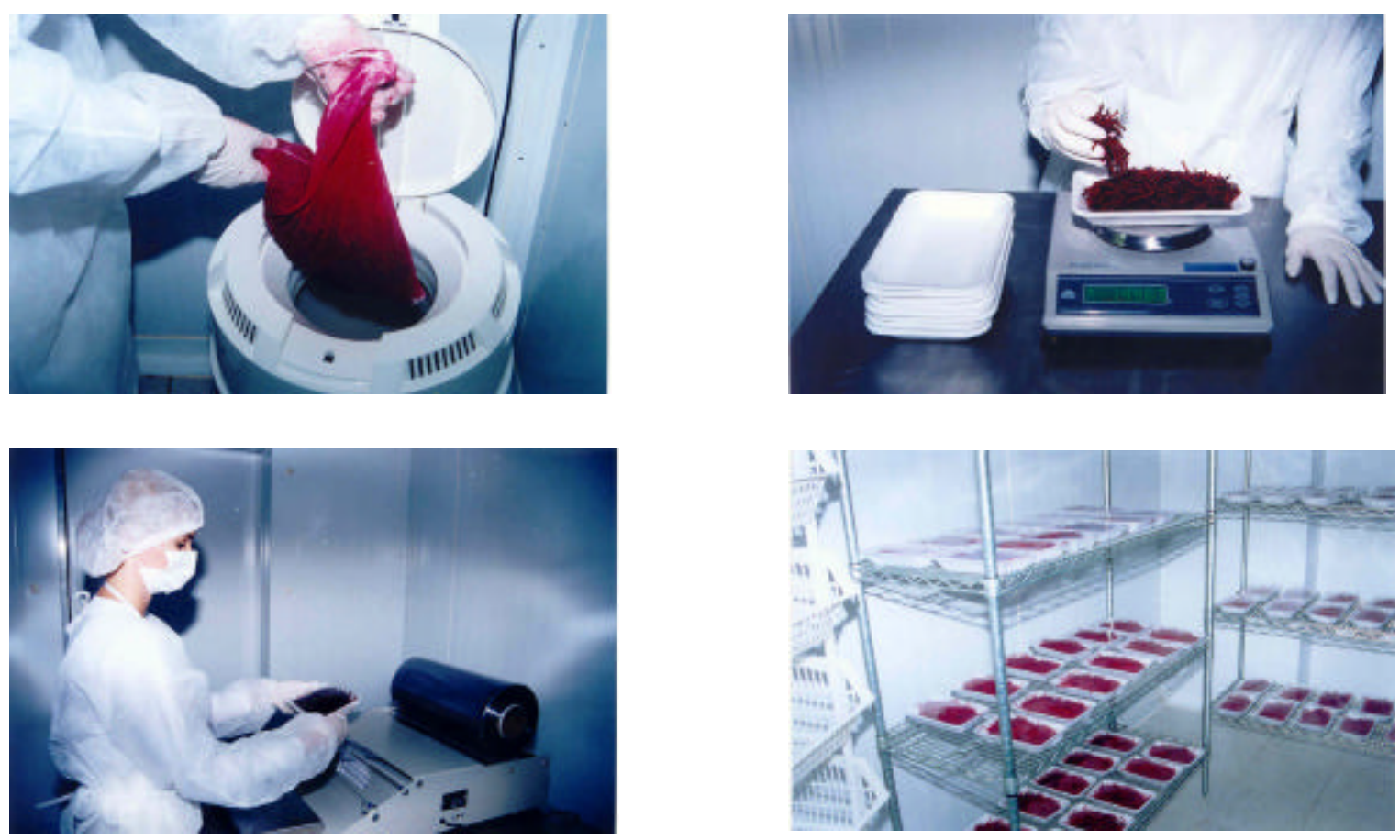
ANEXO B - Ficha de avaliação sensorial e escala de notas para análise sensorial de beterrabas minimamente processadas.

FICHA DE AVALIAÇÃO PARA ANÁLISE SENSORIAL DE BETERRABA MINIMAMENTE PROCESSADAS

Nome:

Telefone:

Data:

Muito obrigada por participar de nossa pesquisa.

Por favor, avalie a amostra de acordo com a escala abaixo:

\begin{tabular}{|l|c|c|c|c|c|}
\hline Variável & \multicolumn{5}{|c|}{ Tratamento } \\
& 1 & 2 & 3 & 4 & 5 \\
\hline Aparência & & & & & \\
\hline
\end{tabular}

\section{ESCALAS DE NOTAS}

1. Péssimo

3. Ruim

5. Regular

7. Boa

9. Excelente

\section{Comentários:}

Indique o que em particular você mais gostou ou menos gostou neste produto (use palavras ou frases):

Mais gostei:

Menos gostei: 
ANEXO C - Procedimento para contagem de bactérias psicrotróficas.
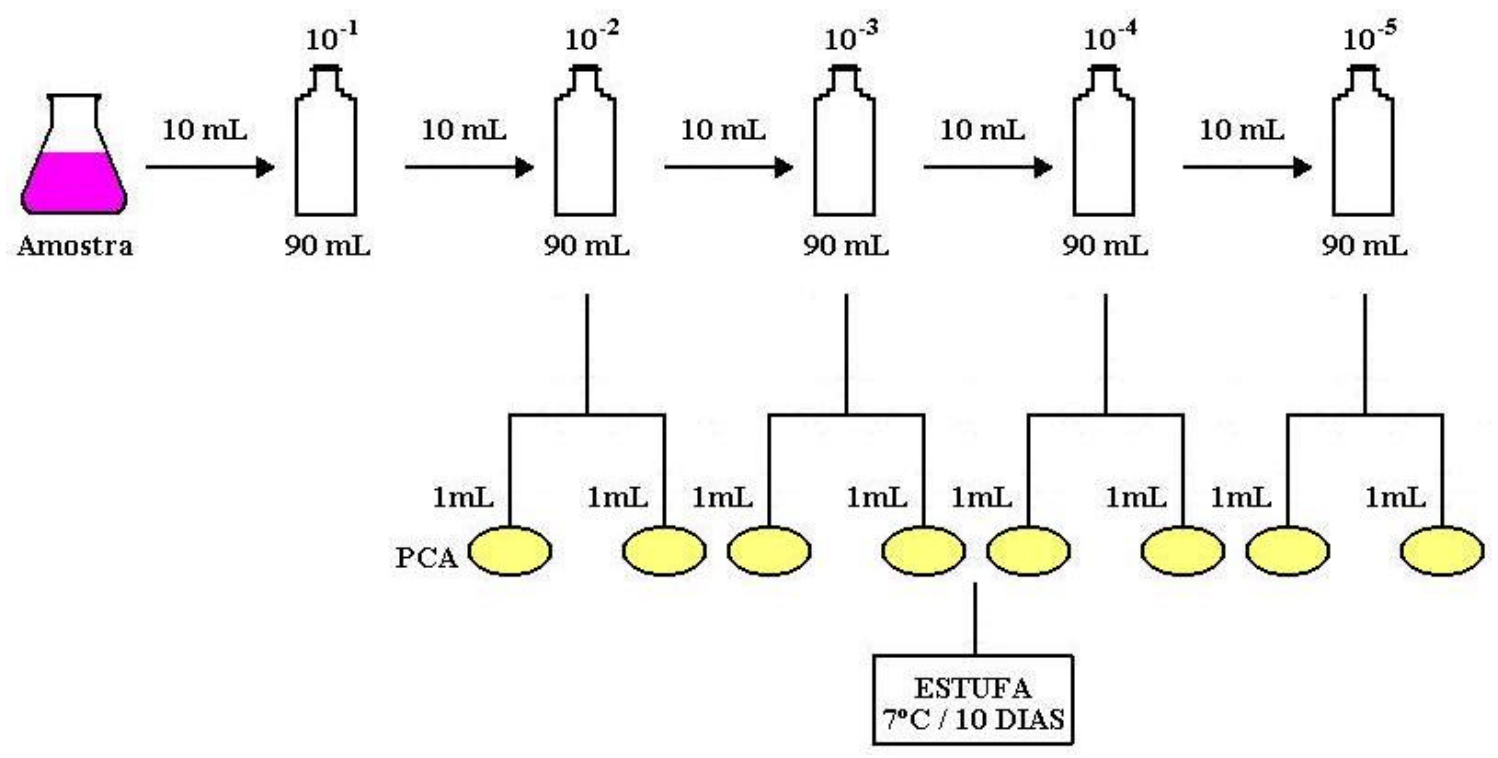

ANEXO D - Procedimento para contagem de coliformes totais e fecais.

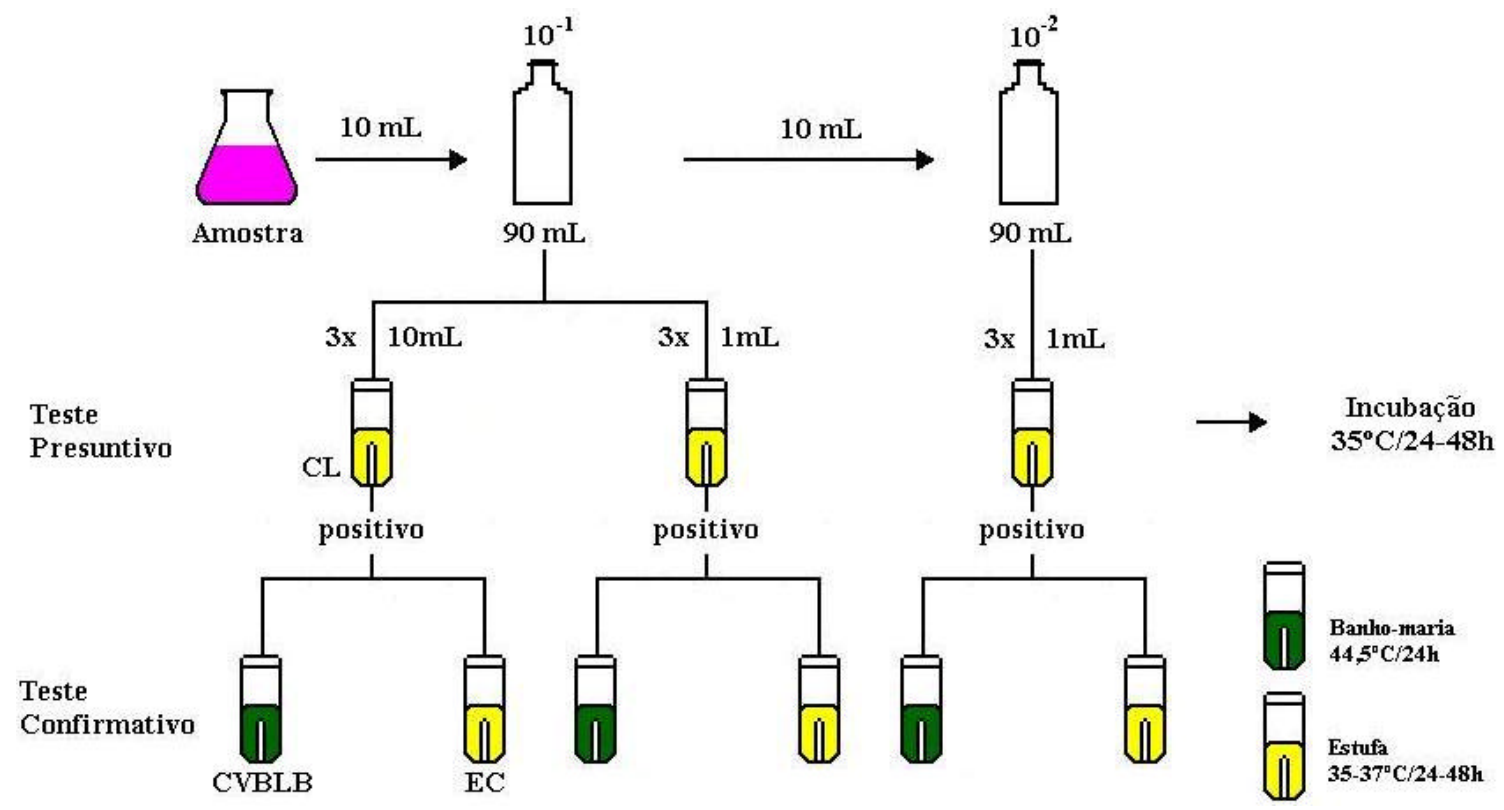


ANEXO E - Número mais provável (NMP) para várias combinações de resultados possíveis, quando três tubos são usados por diluição (inoculações de 1, 0,1 e 0,01g ou $\mathrm{mL}$ da amostra).

\begin{tabular}{|c|c|c|c|c|c|c|c|}
\hline \multicolumn{4}{|c|}{ Combinação de tubos positivos } & \multicolumn{4}{|c|}{ Combinação de tubos positivos } \\
\hline $1,0 \mathrm{~g}-\mathrm{mL}$ & $0,1 \mathrm{~g}-\mathrm{mL}$ & $0,01 \mathrm{~g}-\mathrm{mL}$ & NMP & $1,0 \mathrm{~g}-\mathrm{mL}$ & $0,1 \mathrm{~g}-\mathrm{mL}$ & $0,01 \mathrm{~g}-\mathrm{mL}$ & NMP \\
\hline 0 & 0 & 0 & $<0,3$ & 2 & 0 & 0 & 0,91 \\
\hline 10 & 0 & 1 & 0,3 & 2 & 0 & 1 & 1,4 \\
\hline 0 & 0 & 2 & 0,6 & 2 & 0 & 2 & 20 \\
\hline 0 & 0 & 3 & 0,9 & 2 & 0 & 3 & 2,6 \\
\hline 0 & 1 & 0 & 0,3 & 2 & 1 & 0 & 1,5 \\
\hline 0 & 1 & 1 & 0,61 & 2 & 1 & 1 & 2,0 \\
\hline 0 & 1 & 2 & 0,92 & 2 & 1 & 2 & 2,7 \\
\hline 0 & 1 & 3 & 1,2 & 2 & 1 & 3 & 3,4 \\
\hline 0 & 2 & 0 & 0,62 & 2 & 2 & 0 & 2,1 \\
\hline 0 & 2 & 1 & 0,93 & 2 & 2 & 1 & 2,8 \\
\hline 0 & 2 & 2 & 1,2 & 2 & 2 & 2 & 3,5 \\
\hline 0 & 2 & 3 & 1,6 & 2 & 2 & 3 & 4,2 \\
\hline 0 & 3 & 0 & 0,94 & 2 & 3 & 0 & 2,9 \\
\hline 0 & $\mathrm{e}$ & 1 & 1,3 & 2 & 3 & 1 & 3,6 \\
\hline 0 & 3 & 2 & 1,6 & 2 & 3 & 2 & 4,4 \\
\hline 0 & 3 & 3 & 1,9 & 2 & 3 & 3 & 5,3 \\
\hline 1 & 0 & 0 & 0,36 & 3 & 0 & 0 & 2,3 \\
\hline 1 & 0 & 1 & 0,72 & 3 & 0 & 1 & 3,9 \\
\hline 1 & 0 & 2 & 1,1 & 3 & 0 & 2 & 6,4 \\
\hline 1 & 0 & 1 & 1,5 & 3 & 0 & 3 & 9,5 \\
\hline 1 & 1 & 0 & 0,73 & 3 & 1 & 0 & 4,3 \\
\hline 1 & 1 & 1 & 1,1 & 3 & 1 & 1 & 7,5 \\
\hline 1 & 1 & 2 & 1,5 & 3 & 1 & 2 & 12 \\
\hline 1 & 1 & 3 & 1,9 & 3 & 1 & 3 & 16 \\
\hline 1 & 2 & 0 & 1,1 & 3 & 2 & 0 & 9,3 \\
\hline 1 & 2 & 1 & 1,5 & 3 & 2 & 1 & 15 \\
\hline 1 & 2 & 2 & 2,0 & 3 & 2 & 2 & 21 \\
\hline 1 & 2 & 3 & 2,4 & 3 & 2 & 3 & 29 \\
\hline 1 & 3 & 0 & 1,6 & 3 & 3 & 0 & 24 \\
\hline 1 & 3 & 1 & 2,0 & 3 & 3 & 1 & 46 \\
\hline 1 & 3 & 2 & 2,4 & 3 & 3 & 2 & 110 \\
\hline 1 & 3 & 3 & 2,9 & 3 & 3 & 3 & $>110$ \\
\hline
\end{tabular}

Nota: Os valores de NMP são calculados partindo-se porções iniciais de $1 \mathrm{~g}$ ou $\mathrm{mL}$ da amostra.

Fonte: ABNT (1991) - MB 3463. 


\section{REFERÊNCIAS BIBLIOGRÁFICAS}

AGÊNCIA NACIONAL DE VIGILÂNCIA SANITÁRIA. Resolução - RDC no 12, de 2 de janeiro de 2001. www.anvisa.gov.br/legis/resol/12 01rdc.htm (21 fev. 2002).

ALMEIDA, M.E.M. Processamento mínimo de frutas. In: SEMINÁRIO SOBRE PRODUTOS HORTIFRUTÍCOLAS MINIMAMENTE PROCESSADOS, Campinas, 1998. Palestra. Campinas: FRUTHOTEC; ITAL, 1998. p. 1-13.

ASSOCIAÇÃO BRASILEIRA DE NORMAS TÉCNICAS. Bactérias coliformes totais, coliformes fecais e Escherichia coli em alimentos: determinação do número mais provável (NMP): MB-3463. Rio de Janeiro, 1991. 7p.

ATTOE, E.L.; ELBE, J.H.V. Oxygen involvement betanine degradation: effect of antioxidants. Journal of Food Science, v. 50, p. 106, 1985.

AVENA-BUSTILLOS, R.J.; CISNEROS-ZEVALLOS, L.A.; KROCHTA, J.M. et al. Application of casein-lipid edible film emulsions to reduce white bush on minimally processed carrots. Postharvest Biology and Technology, v.4, n.4, p.319-329,1994. 
BASTRASH, S.; MAKHLOUF, J.; CASTAIGNE, F. et al. Optimal controlled atmosphere conditions for storage of broccoli florets. Journal of Food Science, v.58, n.2, p.338-341, 360, Mar./Apr., 1993.

BOBBIO, P.A.; BOBBIO, F.O. Química do processamento de alimentos. Campinas: Fundação Cargill, 1984. 232p.

BOLIN, H.R.; HUXSOLL, C.C. Storage stability of minimally processed fruit. Journal of Food Processing and Preservation, v.13, p. 281-292, 1989.

BOLIN, H.R.; HUXSOLL, C.C. Control of minimally processed carrot (Dacus carota) surface discoloration caused by abrasion peeling. Journal of Food Science, v.56, n.2, p.416-418, 1991.

BOWER, J. P.; VAN LELYVELD, L. J. The effects of stress history and container ventilation on avocado fruits polyphenol oxidase activity. Journal of Horticultural Science, v.60, p.545-547, 1985.

BRACKETT, R.E. Shelf stability and safety of fresh cut produce as influenced by sanitation and desinfection. Journal of Food Protection, v. 55, p. $808-814$, 1992.

BRECHT, J.K. Physiology of ligthy processed fruits and vegetables. Hortscience, v. 30, n. 1, p. 18-22, 1995. 
BURG, S.P.; BURG, E.A. Molecular requeriments for the biological activity of ethylene. Plant Physiology, v.42, p.144-152, 1967.

CAMARGO, L.S. As hortaliças e seu cultivo. Campinas: Fundação Cargill, 1981. 321p.

CANTWELLL , M.I. Posharvest handling systems: minimally processed fruits and vegetables. In: KDRE, A.A. (Ed.). Postharvest technology of horticultural crops. Oakland: University of California, 1992. cap.32, p.277281.

CANTWELL, M.I. Preparation and quality of fresh-cut produce. In: ENCONTRO NACIONAL SOBRE PROCESSAMENTO MÍNIMO DE FRUTAS E HORTALIÇAS, 2., Viçosa, 2000. Proceedings. Viçosa: Universidade Federal de Viçosa, 2000. p.156-182.

CARUSO, J.G.B.; CAMARGO, R. Microbiologia de alimentos. In: CAMARGO, R. (Ed.). Tecnologia dos produtos agropecuários-alimentos. São Paulo: Nobel, 1984. p.35-49.

CHITARRA, A.B.; ALVES, R.E. Tecnologia de pós-colheita para frutas tropicais. Fortaleza: FRUTAL; SINDIFRUTA, 2001. 27p.

CHITARRA, M.I.F. Processamento mínimo de frutos e hortaliças. Viçosa: Centro de Produções Técnicas, 1998. 88p.

CHITARRA, M.I.F.;CHITARRA, A.B. Pós-colheita de frutos e hortaliças. Lavras:ESAL; FAEFE, 1990. 320p. 
CHUMA, Y.; MURATA, S.; IWAMOTO, M. et al. Donner strawberry transportation in refrigerated truck for 700 kilometers. Annals of Agricultural Engineering Society, v.45, p.292-297, 1984.

CISNEROS-ZEVALLOS, L.;SALVEIT, M.E.; KROCHTA, J.M. Mechanism of surface white discoloration of peeled carrots during storage. Journal of Food Science, v. 60, n.2, p. 320-323, 1995.

DURIGAN, J.F.; SARGENT, S.A. Uso de melão Cantaloupe na produção de produtos minimamente processados. Alimentos e Nutrição, v.10, p.69-77, 1999.

ELBE, J.H.V.; SCHWARTZ, S.J.; HILDENBRAND, B.E. Loss and regeneration of betacyanin pigments during processing of red beets. Journal of Food Science, v.46, p.1713, 1981.

ELBE, J.H.V.; SY, S.H., MAING, I.Y. Quantitative analysis of betacyanins in red table beets (Beta vulgaris L.) Journal of Food Science, v.37, p. 932, 1972.

FENENA, O.R. Quimica de los alimentos. 2.ed. Zaragoza: Acribia, 1995. $586 p$.

FILGUEIRA, F.A.R. Novo manual de olericultura. Viçosa: UFV, 2000. 402p. 
GARCÍA-GIMENO, R.M.; ZURERA-COSANO, G. Determination of ready-to-eat vegetable salad shelf-life. International Journal of Food Microbiology, v.36, p. 31-38, 1997.

GLENN, G.M.; REDDY, A.S. N.; POOVAIAH, B.W. Effect of calcium on cell wall structure, protein phosphorylation and protein profile in senescence apples. Plant Cell Physiology, v.29, n.4, p.565-572, 1988.

HAJDENWURCEL, J.R. Atlas de microbiologia de alimentos. São Paulo: Fonte, 1998.66p.

HARDENBURG, R. E.; WATADA, A.E.; WANG, C. Y. The commercial storage of fruits, vegetables, and florist and nursey stocks. Betsville; USDA, 1986. 136p.

HIRAISHI, A.; HORIE, S. Species composition and growth temperature characteristics of coliforms in relation to their sources. Journal of General Applied Microbiology, v.28, p.139-154, 1982.

HURST, W.C. Sanitation of lightly processed fruits and vegetables. HortScience, v.30, n.1, p.22-24, 1995.

INTERNATIONAL COMMISSION ON MICROBIOLOGICAL SPECIFCATIONS FOR FOODS. Microorganisms in foods. 2.ed. Toronto: University of Toronto Press, 1978. v.1, 434p. 
INTERNACIONAL FRESH CUT PRODUCT ASSOCIATION. Fresh-cut produce handling guidelines. 3.ed. Newark: Produce Marketing Association, 1999. 39p.

IZUMI, H.; WATADA, A.E.; KO, N.P.et al.. Controlled atmosphere storage of carrots slices, sticks and shreds. Postharvest Biology and Technology, v.9, n.2, p.165-172, 1996.

KANNER, J.; HAREL, S.; GRANIT, R. Betalains: a new class of dietary cationized antioxidants. Journal of Agricultural and Food Chemistry, v.49, n.11, p.5178-5185, 2001.

KASMIRE, R.F.; CANTWELL, M. Postharvest handling sytems: underground vegetables (roots, tubers and bulbs). In: KADER, A.A. (Ed.). Postharvest technology of horticultural crops. Davis: University of California, 1992. p.271-275.

KATO-NOGUCHI, H.; WATADA, A.E. Citric acid reduces the respiration of fresh-cut carrots. HortScience, v.32, p.136, 1997.

KAYS, S.J. Postharvest physiology of perishable plant products. New York: AVI Publ., 1991. 532p.

KE, D.; SALTVEIT J.R.; M.E. Wound induced ethylene production, phenolic metabolism, and susceptibility to russet spotting in iceberg lettuce. Plant Physiology, v.76, p.412-418, 1989. 
KLUGE, R.A; NACHTIGAL, J.C.; FACHINELLO, J.C. et al. Fisiologia e manejo pós-colheita de frutas de clima temperado. 2.ed. Piracicaba: Livraria e Editora Rural, 2002. 214p.

LELIÉVRE, J.M.; LATCHÉ, A.; JONES, B. et al. Ethylene and fruit ripening. Physiologia Plantarum, v.101, p.727-739, 1997.

MADDEN, J.M. Microbiol pathogens in fresh cut produce the regulatory perspective. Journal of Food Protection, v.55, p. 821-823, 1992.

MAZZUZ, C.F. Calidad de frutos cítricos: manual para su gestion desde la recoleccion hasta la expedicion. Barcelona: Ed. de Horticultura, 1996.

MORETTI, C.L. Processamento mínimo de hortaliças: alternativa viável para a redução de perdas pós-colheita e agregação de valor ao agronegócio brasileiro. Horticultura Brasileira, v. 17, n.2, p.1, 1999.

MORETTI, C.L. Processamento mínimo de hortaliças: tendências e desafios. Horticultura Brasileira, v.19, n.2, p.172, 2001.

MORETTI, C.L.; SARGENT, S.A. Alteração de aroma e sabor em frutos de tomate com desordem fisiológica causada por impacto. Scientia Agricola, 57, p.385-388, 2000.

MORETTI, C.L.; SARGENT, S.A. Fresh-cut growth in Brazil. Fresh-cut Magazine, v.10, p.24-29, 2002. 
MORETTI, C. L.; MAROUELLI, W. A.; SILVA, W. L.C. Respiratory activity and browning of minimally processed sweet potatoes. Horticultura Brasileira, v.20, p.497-500, 2002a.

MORETTI, C. L.; SILVA, W.L.; ARAUJO, A. L. Quality attributes and carbon dioxide evolution of bell peppers as affected by minimal processing and storage temperature. Proceedings of the Florida State for Horticultural Society, v.113, p.156-159, 2000.

MORETTI, C. L.; BALDWIN, E.; SARGENT, S.A. et al. Internal bruising alters aroma Volatile profiles in tomato fruit tissues. HortScience, v. 37, p.378382, 2002b.

MORETTI, C.L..; SARGENT, S.A.; HUBER, D.J. et al. Chemical composition and physical properties of pericarp, locule and placental tissues of tomatoes with internal bruising. Journal of the American Society for Horticultural Science, v.123, p.656-660, 1998.

NGUYEN-the, C.; CARLIN, F. The microbiology of minimally processed fresh fruits and vegetables. Critical Reviews in Food Science and Nutrition, v.34, n.4, p. 371-401, 1994.

NICOLI, M.C.; ANESE, M.; SEVERINI, C. Combined effects in preventing enzymatic browning reactions in minimally processed fruit. Journal of Food Quality, v.17, p.221-229, 1994. 
NILSON, T. Studies into the pigments in beetroot (Beta vulgaris L. ssp. vulgaris var. rubra L.). Lantbrukhogskolans Annaler, v. 36, p.179-219, 1970.

NILSON, T. The pigment content in beetroot with regard to cultivar, growth, development and growing conditions. Swedish Journal of Agriculture Research, v.3, n. 4, p. 187-200, 1973.

OLIVEIRA, E.C.M.; VALLE, R.H.P. Aspectos microbiológicos dos produtos hortícolas minimamente processados. Higiene Alimentar, v. 11, n. 78/79, p.50-54, 2000.

OSORNIO, M.M.L.; CHAVES, A.R. Quality changes in stored raw grated beetroots as affected by temperature and packaging film. Journal of Food Science, v. 63, n.2, p. 270-330, 1998.

PERYAM, D.R.; GIRARDDOT, N.F. Advanteced taste method. Food Engineering, v.24, p.58-61, 1952.

PIAGENTINI, A.M.; PIROVANI, M.E.; GUEMES, D.R. et al. Survival and growth of Salmonella hadar on minimally processed cabbage as influencied by storage abuse conditions. Journal of Food Science, v. 62, n. 3, p. 616-618, 1997. 
PILON, L.; FIGUEIREDO, M.; OETTERER, M. et al. Diretrizes para implantação de agroindústria para processamento mínimo de hortaliças: cenoura e pimentão (compact disc). In: CONGRESSO BRASILEIRO DE CIÊNCIA E TECNOLOGIA DE ALIMENTOS, 18., Porto Alegre, 2002. Anais. Porto Alegre: SBCTA, 2002.

PURVIS, A.C. The role of adaptive enzymes in carbohydrates oxidation by stressed and senescing plant tissues. HortScience, v.32, n.7, p.1165-1168, 1997.

ROJO, F.; SAABOR, A. Hortifrútis embalados e pré-processados. SuperHiper, v.28, p.8-14, 2002.

ROLLE, R.; CHISM, G.W. Phisiological consequences of minimally processed fruits and vegetables. Journal of Food Quality, v.10, p.157-165, 1987.

ROSEN, J.; KADER, A.A. Postharvest physiology and quality maintenance sliced pear and strawberry fruits. Journal of Food Science, v.54, p.656659, 1989.

SAKR, S.; NOUBAHNI, M.; BOURBOULOUX, A. et al. Cutting, ageing and expression of plant membrane transporters. Biochimica et Biophysica Acta, v. 1330, p. 207-216, 1997. 
SALGADO, S.M.A. Estudo da estabilidade de betalaína extraída da beterrabavermelha de mesa (Beta vulgaris L.) Viçosa, 1997. 48p. (Mestrado) Universidade Federal de Viçosa.

SAPERS, M.G.; HORNSTEIN, J.S. Varietal differences in colorant properties and stability of red beet pigments. Journal of Food Science, v. 44, p.1245, 1979.

SHEWFELT, R.L. Postharvest treatment for extending the shelf life of fruits and vegetables. Food Technology, n.5, p.70-80, 1987.

SIGRIST, J.M.M. Hortaliças minimamente processadas e fatores que afetam sua qualidade. In: CONGRESSO BRASILEIRO DE OLERICULTURA, 38., Petrolina, 1998. Anais Petrolina: SOB,1998.

SILVA, N. da; JUNQUEIRA, V.C.A.; SILVEIRA,N.F.A. Manual de métodos de análise microbilógica de alimentos. São Paulo: Varela, 2001. 317p.

SMYTH, A.B.; SONG, J. CAMERON, A.C. Modified atmosphere packaged cut Iceberg lettuce: effect of temperature and $\mathrm{O}_{2}$ partial pressure on respiration and quality. Journal of Agricultural and Food Chemistry, v.46, n.11, p.4556-4562, 1998.

TATSUMI, Y.; WATADA, A.E.; LING, P.P. Sodium chlorine treatment or waterjet slicing effects on white tissue development on carrot sticks. Journal of Food Science, v. 58, n.6, p. 1390-1392, 1993. 
TURNER, J.F.; TURNER, D.H. In: DAVIES, D.D. (Ed.). The biochemistry of plants. New York: Academic Press, 1980. v.2, p. 281-316.

VANETTI, M.C.D. Controle microbiológico e higiene no processamento mínimo.. In: ENCONTRO NACIONAL SOBRE PROCESSAMENTO MÍNIMO DE FRUTAS E HORTALIÇAS, 2., Viçosa, 2000. Palestras. Viçosa: Universidade Federal de Viçosa, 2000. p.44-52.

WATADA, A.E.; ABE, K.; YAMUCHI, N. Physiological activities of partially processed fruits and vegetables. Food Technology, v.44, p.116-122, 1990.

WILEY, R.C. Minimally processed refrigerated fruits and vegetables. New York: Chapman \& Hall, 1994. 368p.

WILLS, R.H.H.; LEE T.H.; GRAHAM, W.B. et al. Postharvest-an introduction to the physiology and handling of fruit and vegetables. Kensington: New South Wales University Press, 1981. 161p.

YANG, S.F. Biosynthesis and action of ethylene. HortScience, v.20, n.1, p.4145, 1985. 